nephron

Practice

\title{
UK Renal Registry 17th Annual Report: Chapter 8 Biochemical Variables amongst UK Adult Dialysis Patients in 2013: National and Centre-specific Analyses
}

\author{
Catriona Shaw $^{\mathrm{a}}$, Johann Nicholas ${ }^{\mathrm{b}}$, David Pitcher ${ }^{\mathrm{a}}$, Anne Dawnay ${ }^{\mathrm{c}}$ \\ aUK Renal Registry, Bristol, UK; ${ }^{\mathrm{b}}$ Royal Wolverhampton NHS Trust, UK; ' University College London Hospitals, London, UK
}

\section{Key Words}

Bicarbonate - Biochemical variables - Calcium - Dialysis . Haemodialysis - Parathyroid hormone - Peritoneal dialysis . Phosphate · Quality improvement

\begin{abstract}
Introduction: The UK Renal Association clinical practice guidelines include clinical performance measures for biochemical variables in dialysis patients. The UK Renal Registry (UKRR) annually audits dialysis centre performance against these measures as part of its role in promoting continuous quality improvement. Methods: Cross sectional performance analyses were undertaken to compare dialysis centre achievement of clinical audit measures for prevalent haemodialysis (HD) and peritoneal dialysis (PD) cohorts in 2013. The biochemical variables studied were phosphate,
\end{abstract}

adjusted calcium, parathyroid hormone and bicarbonate. In addition, longitudinal analyses were performed (20022013) to show changes in achievement of clinical performance measures over time. Results: Fifty-seven percent of HD and $62 \%$ of PD patients achieved a phosphate within the range recommended by the RA clinical practice guidelines. Seventy-eight percent of HD and of PD patients had adjusted calcium between 2.2-2.5 mmol/L. Fifty-seven percent of HD and $63 \%$ of PD patients had parathyroid hormone between 16-72 pmol/L. Fifty-nine percent of HD and $79 \%$ of PD patients achieved the audit measure for bicarbonate. There was significant inter-centre variation for all variables studied. Conclusions: The UKRR consistently demonstrates significant inter-centre variation in achievement of biochemical clinical audit measures. Understanding the causes of this variation is an important part of improving the care of dialysis patients in the UK.
Catriona Shaw

UK Renal Registry, Southmead Hospital, Southmead Road, Bristol, BS10 5NB, UK

Email: renalregistry@renalregistry.nhs.uk 


\section{Introduction}

The UK Renal Registry (UKRR) collects routine biochemical data from clinical information systems in renal centres in England, Wales and Northern Ireland and receives data from Scotland via the Scottish Renal Registry. Annual cross sectional analyses are undertaken on some of these variables to determine centre level performance against national (Renal Association (RA)) clinical performance measures [1]. This enables UK renal centres to compare their own performance against each other and to the UK average performance. Currently the 5th edition of the UK Renal Association clinical practice guidelines is in practice [1]. This edition commenced in a graded manner in 2009 and includes an expanded number of guideline modules compared to previous editions.

Audit measures for kidney disease increasingly include tighter specification limits in conjunction with a growing evidence base. Out of range observations (e.g. hyperphosphataemia and hypophosphataemia) need to be interpreted cautiously as they may relate to different clinical problems or population characteristics. These will therefore require different strategies to improve centre performance of clinical audit measures. Summary statistical data have been provided to enhance understanding of the population characteristics of each centre and longitudinal analyses to demonstrate changes over time.

Data are also available on the UKRR data portal at www.renalregistry.org.

Table 8.1 lists the recommended biochemical based audit measures from the RA which are relevant to the dialysis population. Several of the audit measures are not currently reported by the UKRR in its annual report; the reasons behind this are varied, but predominantly relate to a high proportion of incomplete data or that the relevant variable is not currently within the specified UKRR dataset. Over time it is hoped to work with the renal community to improve reporting across the range of recommended standards.

\section{Methods}

The analyses presented in this chapter relate to biochemical variables in the prevalent dialysis cohort in England, Wales and Northern Ireland in 2013. Scotland is also included in analyses of phosphate control. The cohort studied were patients prevalent on dialysis treatment on 31st December 2013. Patients receiving dialysis for less than 90 days and those who had changed modality or renal centre in the last 90 days were excluded. Haemodialysis (HD) and peritoneal dialysis (PD) cohorts were analysed separately. A full definition of the cohort including inclusion and exclusion criteria is available in appendix B (www.renalreg.org).

The biochemical variables analysed in this chapter were serum phosphate, calcium, parathyroid hormone and bicarbonate. The method of data collection and validation by the UKRR has been previously described [2]. In brief, for each quarter of 2013 the UKRR extracted biochemical data electronically from clinical information systems in UK dialysis centres. The UKRR does not currently collect data regarding different assay methods mainly because a single dialysis centre may process samples in several different laboratories. Scottish centres have only been included in analyses relating to phosphate control, with data for their prevalent dialysis cohort being supplied directly by the Scottish Renal Registry. The audit measure used for serum phosphate was 1.1-1.7 $\mathrm{mmol} / \mathrm{L}$ in both the HD and PD cohorts [1,3]. For centres providing adjusted calcium values, these data were analysed directly as it is these values on which clinical decisions within centres are based. For centres providing unadjusted calcium values, a formula in widespread use was used to calculate adjusted calcium [4]. The audit measure for adjusted calcium depends on the local reference range [3]. For the purposes of these analyses, the UKRR has used the RA guideline standard of adjusted calcium between 2.2$2.5 \mathrm{mmol} / \mathrm{L}$ as the audit measure [3]. There are also a variety of methods and reference ranges in use to measure parathyroid hormone $(\mathrm{PTH})$. To enable some form of comparative audit the UKRR has used 2-9 times the median upper limit of the reference range $(8 \mathrm{pmol} / \mathrm{L})$ as the audit measure in line with the 5 th edition of the RA clinical practice guidelines and KDIGO 2009 guidance $[3,5]$. This equates to a PTH range of $16-72 \mathrm{pmol} / \mathrm{L}$. The audit measure used for serum bicarbonate in the HD cohort was $18-24 \mathrm{mmol} / \mathrm{L}$ as per the updated haemodialysis guidelines and in the PD cohort was $22-30 \mathrm{mmol} / \mathrm{L}$. A summary of the current RA audit measures for these variables and conversion factors to SI units are given in table 8.2.

Quarterly values were extracted from the database for the last two quarters for calcium, phosphate and bicarbonate and the last three quarters for PTH. Patients who did not have these data were excluded from the analyses. Data completeness was analysed at centre and country level. All patients were included in analyses but centres with less than $50 \%$ completeness were excluded from plots and tables showing centre level performance. Data were also excluded from plots and tables when there were less than 20 patients with data both at centre or country level. These data were analysed to calculate summary descriptive statistics (maximum, minimum, means with the corresponding standard deviation, medians and interquartile ranges). Where applicable, the percentage achieving the Renal Association standard or other surrogate clinical performance measure was also calculated.

The simultaneous control of all three components of bone and mineral disorder (BMD) parameters were analysed in combination. The proportion of patients with control of none, one, two or three parameters are presented. For the purpose of these analyses a corrected calcium between $2.2-2.5 \mathrm{mmol} / \mathrm{L}$, a phosphate level being maintained at or below $1.7 \mathrm{mmol} / \mathrm{L}$ and a PTH level being at or below $72 \mathrm{pmol} / \mathrm{L}$, were evaluated in combination.

Centres report several biochemical variables with different levels of accuracy, leading to problems in comparative evaluation. 
Table 8.1. Summary of Renal Association audit measures for biochemical variables [1]

\begin{tabular}{lll}
\hline & Currently included in & \\
RA audit measure and clinical guideline & UKRR annual report & Reason \\
\hline
\end{tabular}

CKD-MBD in CKD stage 5D Guidance

Audit measure: Serum calcium in dialysis patients (pre-dialysis Yes for haemodialysis patients) $\quad$ Yes

Audit measure: Serum phosphate in dialysis patients Yes

(pre-dialysis for haemodialysis patients) Yes

Audit measure: Proportion of PTH values within range $0 / 4,1 / 4, \quad$ Yes

$2 / 4,3 / 4$, and $4 / 4$ of the 4 annual measurements of PTH in CKD

Yes Summary measures using data from the

last three quarters for PTH-based analyses stage $5 \mathrm{D}$ patients

are presented, rather than stratified by quarter

Audit measure: Percentage of patients with all parameters

Yes

(calcium/phosphate/PTH) within target range

\section{Peritoneal Dialysis Guidelines}

Audit measure: cumulative frequency curves of plasma Yes

bicarbonate

Yes Summary measures at centre and country level are presented in various formats but not as cumulative frequency curves

\section{Haemodialysis Guidelines}

Audit measure: cumulative frequency curves of potassium concentration

No It is hoped for the next report that data completeness will enable analysis. There are also concerns that potential delays in blood sample processing may result in over estimates of potassium concentrations

Audit measure: Cumulative frequency curves of pre-dialysis Yes Yes Summary measures at centre and country serum calcium and phosphate concentrations level are presented in various formats but not as cumulative frequency curves

Audit measure: Cumulative frequency curves of pre-dialysis serum calcium and phosphate concentrations Summary measures at centre and country level are presented in various formats but not as cumulative frequency curves

\section{Cardiovacular Disease in CKD Guidance}

Audit measure: Record of HbA1c concentrations in IFCC

No Poor data completeness

(mmol/mol) and/or DCCT (\%) units

Audit measure: Cholesterol concentrations in patients

prescribed HMG CoA reductase inhibitors

Partially

The UKRR report summary statistics for total cholesterol. These summary data were presented in 2013 and will be presented again in 2015. Information on LDL, and changes in cholesterol are not currently available within the UKRR data or reliable information on statin prescription

Table 8.2. Summary of clinical audit measures and conversion factors from SI units

\begin{tabular}{llc}
\hline Biochemical variable & Clinical audit measure & Conversion factor from SI units \\
\hline Phosphate & HD patients: $1.1-1.7 \mathrm{mmol} / \mathrm{L}$ & $\mathrm{mg} / \mathrm{dl}=\mathrm{mmol} / \mathrm{L} \times 3.1$ \\
& PD patients: $1.1-1.7 \mathrm{mmol} / \mathrm{L}$ & $\mathrm{mg} / \mathrm{dl}=\mathrm{mmol} / \mathrm{L} \times 4$ \\
Calcium (adjusted) & Normal range (ideally $<2.5 \mathrm{mmol} / \mathrm{L})$ & $\mathrm{ng} / \mathrm{L}=\mathrm{pmol} / \mathrm{L} \times 9.5$ \\
Parathyroid hormone & $2-9$ times upper limit of normal & $\mathrm{mg} / \mathrm{dl}=\mathrm{mmol} / \mathrm{L} \times 6.1$ \\
Bicarbonate & HD patients: $18-24 \mathrm{mmol} / \mathrm{L}$ & \\
\hline
\end{tabular}


For example, in the case of serum bicarbonate, data can be submitted as integer values but some centres submit data to one decimal place. All data has been rounded in an attempt to make all centres more comparable.

The number preceding the centre name in each figure indicates the percentage of missing data for that centre. Funnel plot analyses were used to identify 'outlying centres' [6]. The percentage within range for each standard was plotted against centre size along with the upper and lower 95\% and 99.9\% limits. Centres can be identified on these plots by looking up the number of patients treated in each centre provided in the relevant table and finding this value on the $\mathrm{x}$-axis. Longitudinal analyses were performed for some data to calculate overall changes in achievement of a performance measure annually from 2003 to 2013 and were recalculated for each previous year using the rounding procedure.

All data are presented unadjusted for case-mix.

\section{Results}

\section{Mineral and bone variables}

Phosphate

In 2013 the following Renal Association clinical practice guideline regarding phosphate management was applicable:
Guideline 3.2 CKD-MBD: Serum phosphate in dialysis patients

'We suggest that serum phosphate in dialysis patients, measured before a "short-gap" dialysis session in haemodialysis patients, should be maintained between 1.1 and $1.7 \mathrm{mmol} / \mathrm{L}(2 \mathrm{C})^{\prime}$ [3].

The data completeness for serum phosphate across the UK was $97 \%$ for HD patients and $98 \%$ for PD patients although there was considerable variation between centres (tables 8.3, 8.5). The individual centre means and standard deviations are shown in tables 8.3 and 8.5. Fifty-seven percent (95\% CI 56-58\%) of HD patients and $62 \%(95 \%$ CI $60-63 \%)$ of PD patients achieved a phosphate level within the target range specified by the RA clinical audit measure (tables 8.4, 8.6). The proportion of HD patients with hyperphosphataemia was $30 \%$ and the proportion with hypophosphataemia was $13 \%$ (table 8.4, figures 8.1, 8.2). The proportion of PD patients with hyperphosphataemia was $31 \%$ and the proportion with hypophosphataemia was $7 \%$ (table 8.6, figures $8.3,8.4$ ). There was wide between centre variation

Table 8.3. Summary statistics for phosphate in haemodialysis patients in 2013

\begin{tabular}{|c|c|c|c|c|c|c|c|}
\hline Centre & $\begin{array}{c}\% \\
\text { completeness }\end{array}$ & $\begin{array}{c}\text { Patients with data } \\
\qquad N\end{array}$ & Mean & SD & Median & $\begin{array}{l}\text { Lower } \\
\text { quartile }\end{array}$ & $\begin{array}{l}\text { Upper } \\
\text { quartile }\end{array}$ \\
\hline \multicolumn{8}{|l|}{ England } \\
\hline B Heart & 100.0 & 401 & 1.6 & 0.6 & 1.5 & 1.3 & 1.9 \\
\hline B QEH & 97.1 & 859 & 1.6 & 0.5 & 1.5 & 1.3 & 1.8 \\
\hline Basldn & 99.3 & 151 & 1.4 & 0.5 & 1.4 & 1.1 & 1.7 \\
\hline Bradfd & 100.0 & 186 & 1.5 & 0.5 & 1.4 & 1.1 & 1.8 \\
\hline Brightn & 96.2 & 358 & 1.6 & 0.5 & 1.5 & 1.2 & 1.8 \\
\hline Bristol & 100.0 & 485 & 1.6 & 0.5 & 1.5 & 1.2 & 1.8 \\
\hline Camb & 94.9 & 338 & 1.5 & 0.5 & 1.5 & 1.2 & 1.8 \\
\hline Carlis & 100.0 & 58 & 1.7 & 0.5 & 1.6 & 1.2 & 2.0 \\
\hline Carsh & 95.3 & 665 & 1.6 & 0.5 & 1.5 & 1.2 & 1.8 \\
\hline Chelms & 100.0 & 109 & 1.4 & 0.4 & 1.4 & 1.2 & 1.7 \\
\hline Colchr & 92.7 & 101 & 1.5 & 0.4 & 1.5 & 1.3 & 1.7 \\
\hline Covnt & 100.0 & 354 & 1.6 & 0.5 & 1.5 & 1.3 & 1.9 \\
\hline Derby & 99.5 & 202 & 1.5 & 0.5 & 1.4 & 1.2 & 1.8 \\
\hline Donc & 100.0 & 146 & 1.5 & 0.4 & 1.5 & 1.3 & 1.7 \\
\hline Dorset & 100.0 & 244 & 1.5 & 0.5 & 1.5 & 1.2 & 1.7 \\
\hline Dudley & 95.1 & 155 & 1.6 & 0.5 & 1.6 & 1.3 & 1.8 \\
\hline Exeter & 100.0 & 376 & 1.6 & 0.5 & 1.5 & 1.3 & 1.8 \\
\hline Glouc & 100.0 & 188 & 1.5 & 0.5 & 1.5 & 1.2 & 1.8 \\
\hline Hull & 100.0 & 299 & 1.5 & 0.5 & 1.5 & 1.3 & 1.8 \\
\hline Ipswi & 100.0 & 112 & 1.3 & 0.5 & 1.2 & 0.9 & 1.6 \\
\hline Kent & 99.2 & 373 & 1.7 & 0.6 & 1.6 & 1.3 & 1.9 \\
\hline L Barts & 99.9 & 882 & 1.6 & 0.5 & 1.5 & 1.2 & 1.9 \\
\hline L Guys & 77.3 & 457 & 1.5 & 0.5 & 1.4 & 1.1 & 1.8 \\
\hline L Kings & 99.8 & 465 & 1.5 & 0.4 & 1.4 & 1.2 & 1.7 \\
\hline L Rfree & 99.0 & 681 & 1.5 & 0.5 & 1.5 & 1.2 & 1.8 \\
\hline L St.G & 98.4 & 251 & 1.5 & 0.5 & 1.5 & 1.2 & 1.8 \\
\hline
\end{tabular}


Table 8.3. Continued

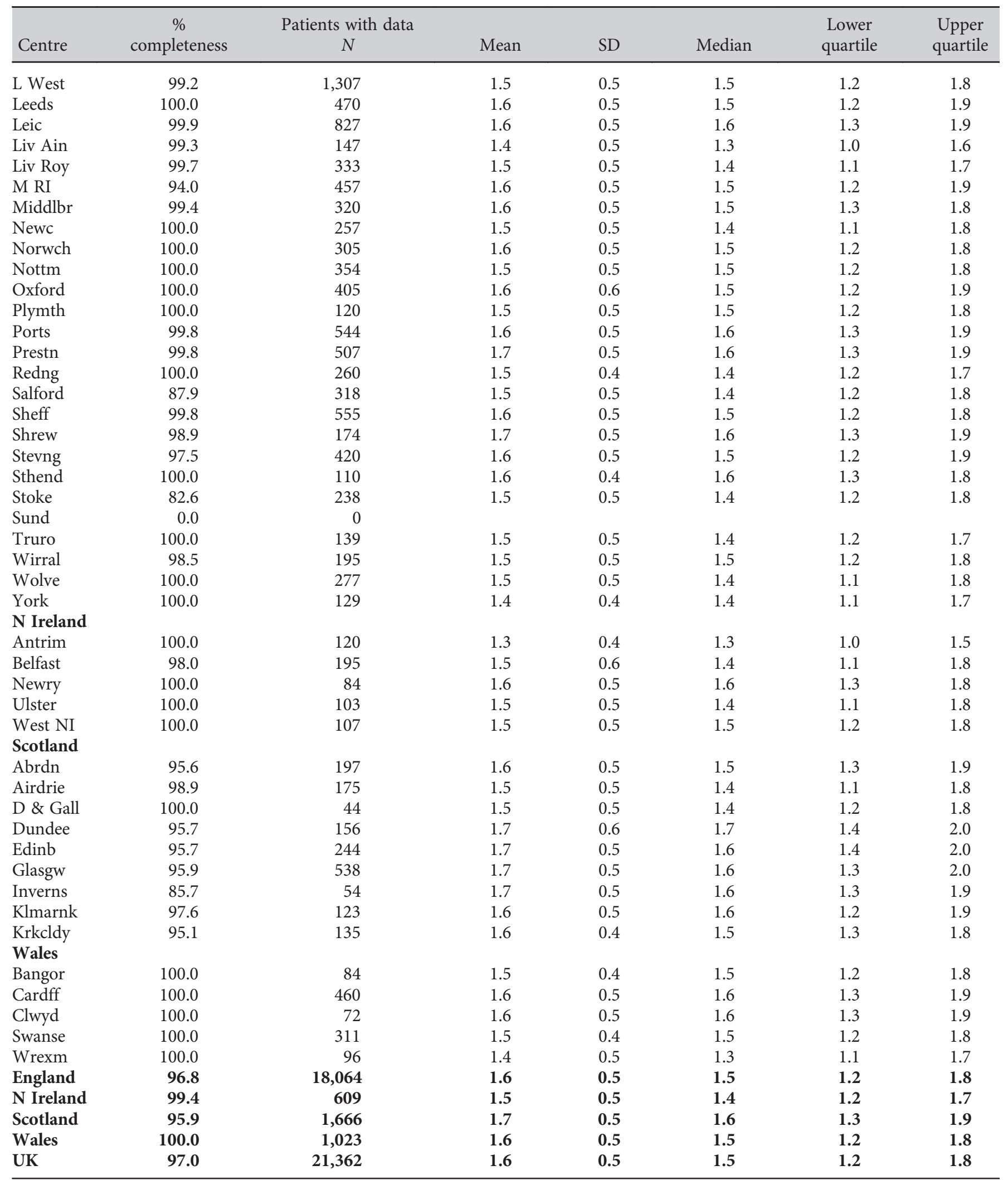

Blank cells: centres excluded from analyses due to low patient numbers or poor data completeness 
Table 8.4. Percentage of haemodialysis patients within, below and above the range specified in the RA audit measure for phosphate $(1.1-1.7 \mathrm{mmol} / \mathrm{L})$ in 2013

\begin{tabular}{|c|c|c|c|c|c|c|c|c|c|}
\hline Centre & $N$ & $\begin{array}{c}\% \text { phos } \\
1.1-1.7 \mathrm{mmol} / \mathrm{L}\end{array}$ & $\begin{array}{l}\text { Lower } \\
95 \% \mathrm{CI}\end{array}$ & $\begin{array}{l}\text { Upper } \\
95 \% \text { CI }\end{array}$ & $\begin{array}{l}\% \text { phos } \\
<1.1 \mathrm{mmol} / \mathrm{L}\end{array}$ & $\begin{array}{c}\% \text { phos } \\
>1.7 \mathrm{mmol} / \mathrm{L}\end{array}$ & $\begin{array}{l}\text { Change in } \% \\
\text { within range } \\
\text { from } 2012\end{array}$ & $\begin{array}{c}95 \% \\
\text { LCL } \\
\text { change }\end{array}$ & $\begin{array}{c}95 \% \\
\text { UCL } \\
\text { change }\end{array}$ \\
\hline B Heart & 401 & 54.9 & 50.0 & 59.7 & 10.2 & 34.9 & 2.5 & -4.4 & 9.4 \\
\hline B QEH & 859 & 62.9 & 59.6 & 66.0 & 9.3 & 27.8 & 4.8 & 0.1 & 9.4 \\
\hline Basldn & 151 & 55.0 & 47.0 & 62.7 & 21.2 & 23.8 & -7.8 & -19.0 & 3.4 \\
\hline Bristol & 485 & 58.6 & 54.1 & 62.9 & 11.8 & 29.7 & 4.8 & -1.6 & 11.1 \\
\hline Camb & 338 & 61.2 & 55.9 & 66.3 & 11.8 & 26.9 & -3.9 & -11.3 & 3.5 \\
\hline Carlis & 58 & 53.5 & 40.7 & 65.8 & 6.9 & 39.7 & 0.8 & -17.4 & 19.1 \\
\hline Carsh & 665 & 56.5 & 52.7 & 60.3 & 12.3 & 31.1 & -2.2 & -7.5 & 3.2 \\
\hline Chelms & 109 & 67.0 & 57.6 & 75.1 & 16.5 & 16.5 & 1.7 & -10.6 & 13.9 \\
\hline Dorset & 244 & 59.8 & 53.6 & 65.8 & 15.6 & 24.6 & 5.1 & -3.7 & 13.9 \\
\hline Dudley & 155 & 53.6 & 45.7 & 61.3 & 11.6 & 34.8 & 0.9 & -10.2 & 12.1 \\
\hline Exeter & 376 & 60.6 & 55.6 & 65.5 & 12.2 & 27.1 & 2.6 & -4.5 & 9.8 \\
\hline Glouc & 188 & 60.1 & 53.0 & 66.9 & 13.3 & 26.6 & 1.4 & -8.5 & 11.2 \\
\hline Hull & 299 & 64.2 & 58.6 & 69.5 & 10.0 & 25.8 & 4.9 & -2.8 & 12.7 \\
\hline Ipswi & 112 & 45.5 & 36.6 & 54.8 & 37.5 & 17.0 & -14.1 & -26.8 & -1.5 \\
\hline Kent & 373 & 53.4 & 48.3 & 58.4 & 9.4 & 37.3 & -0.3 & -7.6 & 6.9 \\
\hline L Barts & 882 & 52.6 & 49.3 & 55.9 & 14.1 & 33.3 & 1.1 & -3.6 & 5.8 \\
\hline L Guys & 457 & 54.7 & 50.1 & 59.2 & 19.5 & 25.8 & -4.4 & -10.6 & 1.8 \\
\hline L Kings & 465 & 65.4 & 60.9 & 69.6 & 14.4 & 20.2 & 1.5 & -4.7 & 7.6 \\
\hline L Rfree & 681 & 59.3 & 55.6 & 63.0 & 13.5 & 27.2 & 2.4 & -3.2 & 7.9 \\
\hline L St.G & 251 & 59.4 & 53.2 & 65.3 & 14.7 & 25.9 & 4.4 & -4.2 & 12.9 \\
\hline Newc & 257 & 57.2 & 51.1 & 63.1 & 16.3 & 26.5 & 0.7 & -7.8 & 9.2 \\
\hline Norwch & 305 & 59.0 & 53.4 & 64.4 & 10.8 & 30.2 & -0.5 & -8.3 & 7.3 \\
\hline Nottm & 354 & 57.1 & 51.9 & 62.1 & 13.8 & 29.1 & -0.8 & -8.1 & 6.4 \\
\hline Oxford & 405 & 50.6 & 45.8 & 55.5 & 17.3 & 32.1 & -3.7 & -10.7 & 3.2 \\
\hline Plymth & 120 & 57.5 & 48.5 & 66.0 & 13.3 & 29.2 & -2.2 & -14.6 & 10.3 \\
\hline Ports & 544 & 50.7 & 46.5 & 54.9 & 14.3 & 34.9 & -1.3 & -7.4 & 4.7 \\
\hline Prestn & 507 & 57.0 & 52.7 & 61.3 & 7.9 & 35.1 & 5.4 & -0.8 & 11.5 \\
\hline Redng & 260 & 62.3 & 56.3 & 68.0 & 13.5 & 24.2 & 4.1 & -4.3 & 12.6 \\
\hline Salford ${ }^{*}$ & 318 & 53.8 & 48.3 & 59.2 & 19.8 & 26.4 & 0.8 & -7.0 & 8.7 \\
\hline Sheff & 555 & 60.7 & 56.6 & 64.7 & 9.0 & 30.3 & 1.4 & -4.3 & 7.2 \\
\hline Shrew & 174 & 57.5 & 50.0 & 64.6 & 6.3 & 36.2 & 3.4 & -6.9 & 13.7 \\
\hline Stevng & 420 & 54.3 & 49.5 & 59.0 & 11.9 & 33.8 & -2.1 & -9.0 & 4.8 \\
\hline Sthend & 110 & 60.9 & 51.5 & 69.6 & 8.2 & 30.9 & 13.7 & 0.6 & 26.8 \\
\hline Stoke & 238 & 62.2 & 55.9 & 68.1 & 10.9 & 26.9 & 4.4 & -4.3 & 13.1 \\
\hline Truro & 139 & 58.3 & 49.9 & 66.2 & 18.0 & 23.7 & 1.1 & -10.6 & 12.9 \\
\hline Wirral & 195 & 54.9 & 47.8 & 61.7 & 15.4 & 29.7 & -1.4 & -11.7 & 8.8 \\
\hline Wolve & 277 & 52.4 & 46.5 & 58.2 & 21.7 & 26.0 & -1.7 & -10.1 & 6.6 \\
\hline York & 129 & 62.8 & 54.2 & 70.7 & 17.8 & 19.4 & 4.1 & -8.0 & 16.2 \\
\hline
\end{tabular}


Table 8.4. Continued

\begin{tabular}{|c|c|c|c|c|c|c|c|c|c|}
\hline Centre & $N$ & $\begin{array}{c}\text { \% phos } \\
1.1-1.7 \mathrm{mmol} / \mathrm{L}\end{array}$ & $\begin{array}{l}\text { Lower } \\
95 \% \text { CI }\end{array}$ & $\begin{array}{l}\text { Upper } \\
95 \% \text { CI }\end{array}$ & $\begin{array}{c}\% \text { phos } \\
<1.1 \mathrm{mmol} / \mathrm{L}\end{array}$ & $\begin{array}{c}\% \text { phos } \\
>1.7 \mathrm{mmol} / \mathrm{L}\end{array}$ & $\begin{array}{l}\text { Change in \% } \\
\text { within range } \\
\text { from } 2012\end{array}$ & $\begin{array}{c}95 \% \\
\text { LCL } \\
\text { change }\end{array}$ & $\begin{array}{c}95 \% \\
\text { UCL } \\
\text { change }\end{array}$ \\
\hline \multicolumn{10}{|l|}{$\mathbf{N}$ Ireland } \\
\hline Antrim & 120 & 60.8 & 51.8 & 69.1 & 30.0 & 9.2 & 4.0 & -8.3 & 16.3 \\
\hline Belfast & 195 & 51.3 & 44.3 & 58.2 & 20.5 & 28.2 & -0.4 & -10.2 & 9.4 \\
\hline Newry & 84 & 58.3 & 47.6 & 68.4 & 10.7 & 31.0 & 7.7 & -7.2 & 22.7 \\
\hline Ulster & 103 & 54.4 & 44.7 & 63.7 & 18.5 & 27.2 & -14.0 & -27.2 & -0.7 \\
\hline West NI & 107 & 59.8 & 50.3 & 68.7 & 11.2 & 29.0 & 6.3 & -6.3 & 19.0 \\
\hline \multicolumn{10}{|l|}{ Scotland } \\
\hline Abrdn & 197 & 55.3 & 48.3 & 62.1 & 11.2 & 33.5 & -1.6 & -11.3 & 8.1 \\
\hline Airdrie & 175 & 61.1 & 53.7 & 68.1 & 12.6 & 26.3 & 12.1 & 1.5 & 22.6 \\
\hline D \& Gall & 44 & 56.8 & 42.0 & 70.5 & 18.2 & 25.0 & 0.3 & -20.2 & 20.8 \\
\hline Dundee & 156 & 50.0 & 42.2 & 57.8 & 9.0 & 41.0 & -2.1 & -12.9 & 8.8 \\
\hline Edinb & 244 & 52.1 & 45.8 & 58.3 & 7.0 & 41.0 & -2.4 & -11.4 & 6.5 \\
\hline Glasgw & 538 & 53.4 & 49.1 & 57.5 & 7.3 & 39.4 & 1.7 & -4.3 & 7.8 \\
\hline Inverns & 54 & 55.6 & 42.2 & 68.1 & 5.6 & 38.9 & 16.7 & -1.9 & 35.2 \\
\hline Klmarnk & 123 & 47.2 & 38.5 & 56.0 & 16.3 & 36.6 & -5.7 & -18.1 & 6.8 \\
\hline Krkcldy & 135 & 60.0 & 51.5 & 67.9 & 8.2 & 31.9 & 3.6 & -8.2 & 15.4 \\
\hline \multicolumn{10}{|l|}{ Wales } \\
\hline Bangor & 84 & 64.3 & 53.5 & 73.8 & 8.3 & 27.4 & -0.3 & -14.9 & 14.2 \\
\hline Cardff & 460 & 55.7 & 51.1 & 60.1 & 9.8 & 34.6 & -2.8 & -9.3 & 3.6 \\
\hline Clwyd & 72 & 55.6 & 44.0 & 66.6 & 11.1 & 33.3 & 1.6 & -14.4 & 17.7 \\
\hline Swanse & 311 & 62.7 & 57.2 & 67.9 & 10.9 & 26.4 & 0.1 & -7.5 & 7.7 \\
\hline Wrexm & 96 & 55.2 & 45.2 & 64.8 & 22.9 & 21.9 & -4.6 & -18.9 & 9.8 \\
\hline England & 18,064 & 57.2 & 56.4 & 57.9 & 13.6 & 29.2 & 1.0 & -0.1 & 2.0 \\
\hline N Ireland & 609 & 56.2 & 52.2 & 60.1 & 19.1 & 24.8 & 0.7 & -4.8 & 6.2 \\
\hline Scotland & 1,666 & 54.1 & 51.7 & 56.5 & 9.4 & 36.5 & 1.5 & -1.9 & 4.9 \\
\hline Wales & $\mathbf{1 , 0 2 3}$ & 58.5 & 55.4 & 61.4 & 11.3 & 30.2 & -1.6 & -5.8 & 2.7 \\
\hline UK & 21,362 & 57.0 & 56.3 & 57.6 & 13.3 & 29.7 & 0.9 & -0.1 & 1.8 \\
\hline
\end{tabular}

*Salford and Manchester RI have been involved in the SPIRiT study - an RCT comparing low phosphate control (0.8 to $1.4 \mathrm{mmol} / \mathrm{L})$ with high phosphate group control (1.8 to $2.4 \mathrm{mmol} / \mathrm{L})$; HD patients only were recruited

Table 8.5. Summary statistics for phosphate in peritoneal dialysis patients in 2013

\begin{tabular}{|c|c|c|c|c|c|c|c|}
\hline Centre & $\begin{array}{c}\% \\
\text { completeness }\end{array}$ & $\begin{array}{c}\text { Patients with data } \\
N\end{array}$ & Mean & SD & Median & $\begin{array}{c}\text { Lower } \\
\text { quartile }\end{array}$ & $\begin{array}{l}\text { Upper } \\
\text { quartile }\end{array}$ \\
\hline \multicolumn{8}{|l|}{ England } \\
\hline B QEH & 100.0 & 129 & 1.6 & 0.4 & 1.5 & 1.2 & 1.9 \\
\hline Basldn & 100.0 & 30 & 1.6 & 0.3 & 1.6 & 1.4 & 1.7 \\
\hline Bradfd & 96.2 & 25 & 1.7 & 0.5 & 1.7 & 1.3 & 2.0 \\
\hline Camb & 94.7 & 18 & & & & & \\
\hline Carlis & 100.0 & 23 & 1.6 & 0.4 & 1.6 & 1.4 & 1.8 \\
\hline Carsh & 97.1 & 102 & 1.6 & 0.4 & 1.5 & 1.3 & 1.7 \\
\hline Chelms & 95.0 & 19 & & & & & \\
\hline \multicolumn{8}{|l|}{ Colchr } \\
\hline Covnt & 91.7 & 66 & 1.4 & 0.4 & 1.3 & 1.1 & 1.5 \\
\hline Exeter & 100.0 & 63 & 1.5 & 0.4 & 1.5 & 1.3 & 1.8 \\
\hline Glouc & 100.0 & 31 & 1.6 & 0.4 & 1.5 & 1.3 & 1.9 \\
\hline Hull & 100.0 & 72 & 1.6 & 0.4 & 1.5 & 1.4 & 1.8 \\
\hline Ipswi & 100.0 & 24 & 1.6 & 0.5 & 1.4 & 1.2 & 1.8 \\
\hline Kent & 98.3 & 56 & 1.5 & 0.4 & 1.5 & 1.3 & 1.8 \\
\hline L Barts & 98.9 & 176 & 1.5 & 0.4 & 1.5 & 1.2 & 1.8 \\
\hline
\end{tabular}


Table 8.5. Continued

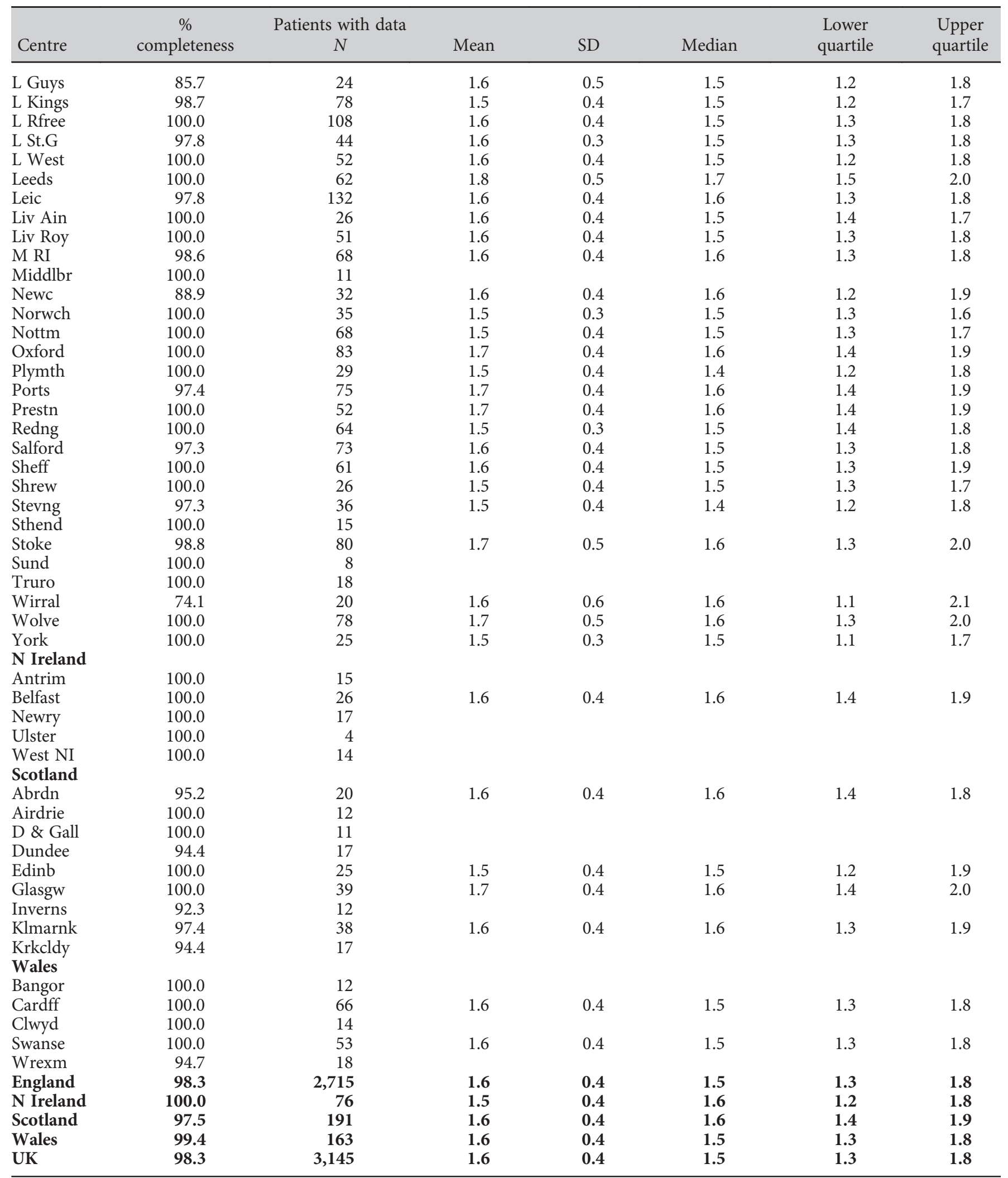

Blank cells: centres excluded from analyses due to low patient numbers or poor data completeness 
Table 8.6. Percentage of peritoneal dialysis patients within, below and above the range specified in the RA audit measure for phosphate $(1.1-1.7 \mathrm{mmol} / \mathrm{L})$ in 2013

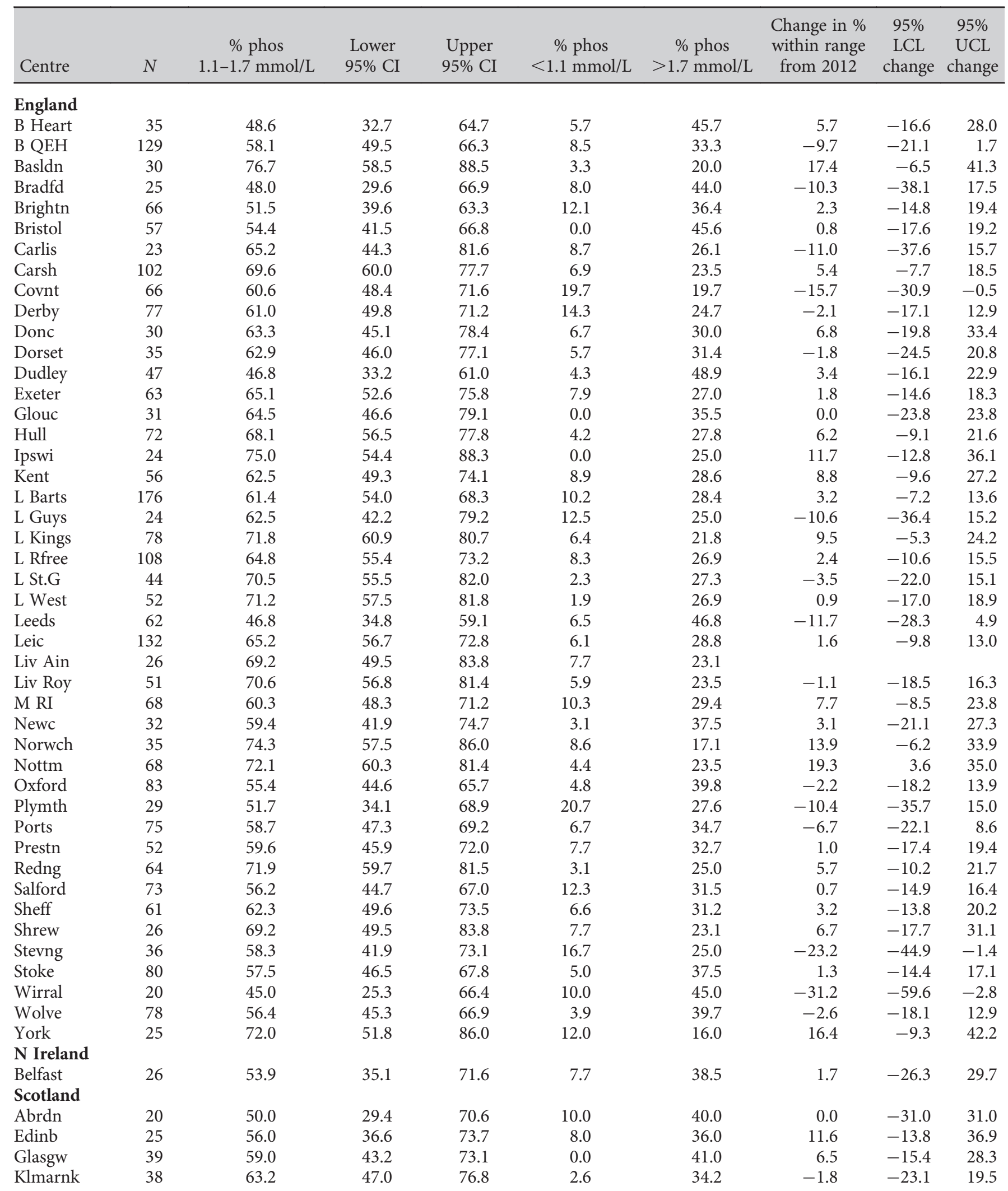


Table 8.6. Continued

\begin{tabular}{|c|c|c|c|c|c|c|c|c|c|}
\hline Centre & $N$ & $\begin{array}{c}\% \text { phos } \\
1.1-1.7 \mathrm{mmol} / \mathrm{L}\end{array}$ & $\begin{array}{l}\text { Lower } \\
95 \% \mathrm{CI}\end{array}$ & $\begin{array}{l}\text { Upper } \\
95 \% \text { CI }\end{array}$ & $\begin{array}{c}\text { \% phos } \\
<1.1 \mathrm{mmol} / \mathrm{L}\end{array}$ & $\begin{array}{c}\% \text { phos } \\
>1.7 \mathrm{mmol} / \mathrm{L}\end{array}$ & $\begin{array}{c}\text { Change in } \% \\
\text { within range } \\
\text { from } 2012\end{array}$ & $\begin{array}{c}95 \% \\
\text { LCL } \\
\text { change }\end{array}$ & $\begin{array}{c}95 \% \\
\text { UCL } \\
\text { change }\end{array}$ \\
\hline \multicolumn{10}{|l|}{ Wales } \\
\hline Cardff & 66 & 68.2 & 56.1 & 78.3 & 6.1 & 25.8 & 3.9 & -12.0 & 19.8 \\
\hline Swanse & 53 & 67.9 & 54.3 & 79.0 & 5.7 & 26.4 & -1.9 & -19.5 & 15.7 \\
\hline England & 2,715 & 62.0 & 60.1 & 63.8 & 7.7 & 30.4 & 1.1 & -1.5 & 3.6 \\
\hline N Ireland & 76 & 59.2 & 47.9 & 69.6 & 7.9 & 32.9 & -5.5 & -21.3 & 10.3 \\
\hline Scotland & 191 & 56.5 & 49.4 & 63.4 & 4.7 & 38.7 & 2.5 & -7.3 & 12.2 \\
\hline Wales & 163 & 65.0 & 57.4 & 72.0 & 6.1 & 28.8 & -1.6 & -11.8 & 8.5 \\
\hline UK & 3,145 & 61.7 & 60.0 & 63.4 & 7.4 & 30.9 & 0.9 & -1.5 & 3.3 \\
\hline
\end{tabular}

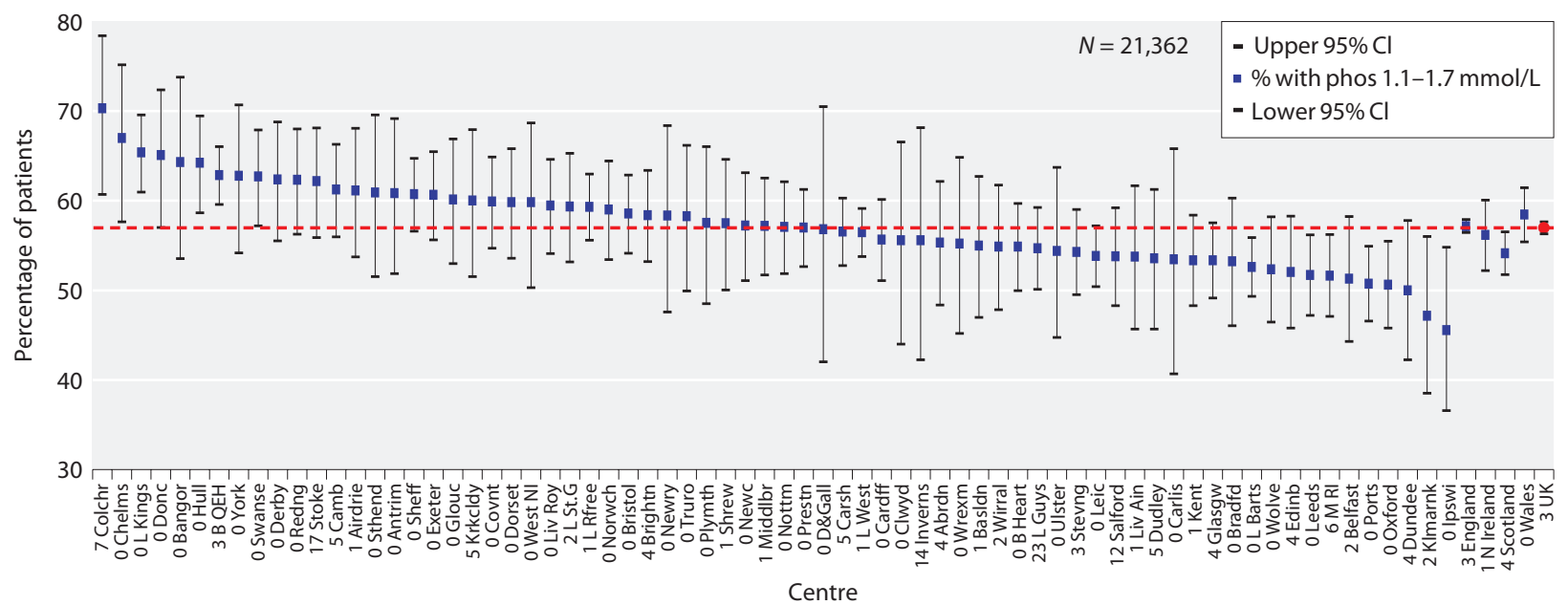

Fig. 8.1. Percentage of haemodialysis patients with phosphate within the range specified by the RA clinical audit measure (1.1$1.7 \mathrm{mmol} / \mathrm{L}$ ) by centre in 2013

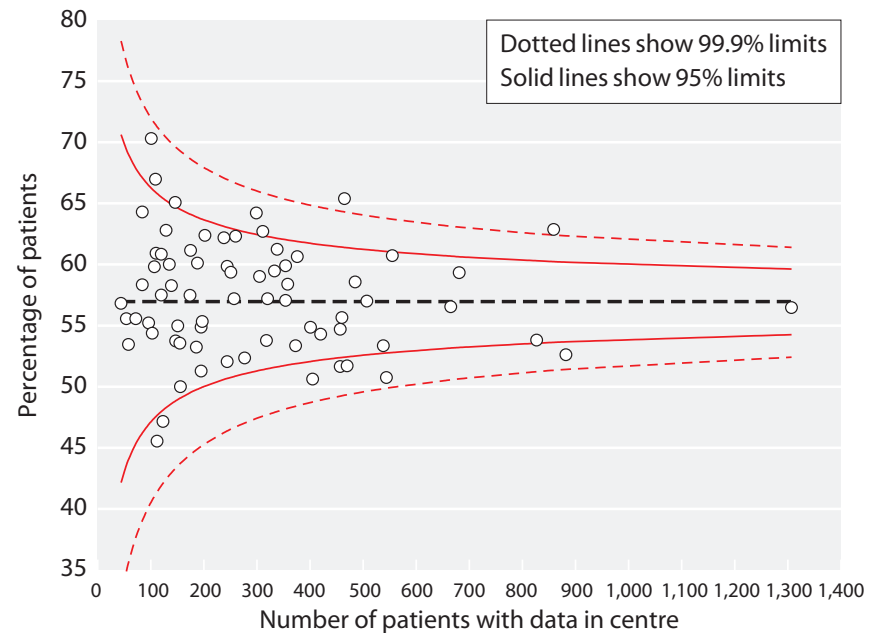

Fig. 8.2. Funnel plot of percentage of haemodialysis patients with phosphate within the range specified by the RA clinical audit measure (1.1-1.7 $\mathrm{mmol} / \mathrm{L}$ ) by centre in 2013 in the proportion of patients below, within and above the phosphate range specified by the clinical performance measure (figures 8.1-8.4).

Longitudinal analysis showed a trend towards improved phosphate control across England, Northern Ireland and Wales combined between 2003 and 2013 that has plateaued in more recent years (figure 8.5). However, this overall plateau masks substantial deterioration in a few centres achieving the standard this year (Ipswich, Ulster for HD patients; Coventry, Stevenage, Wirral for PD patients) that has been countered by improvements in other centres.

\section{Adjusted calcium}

In 2013, the following Renal Association clinical practice guideline regarding calcium management was applicable: 


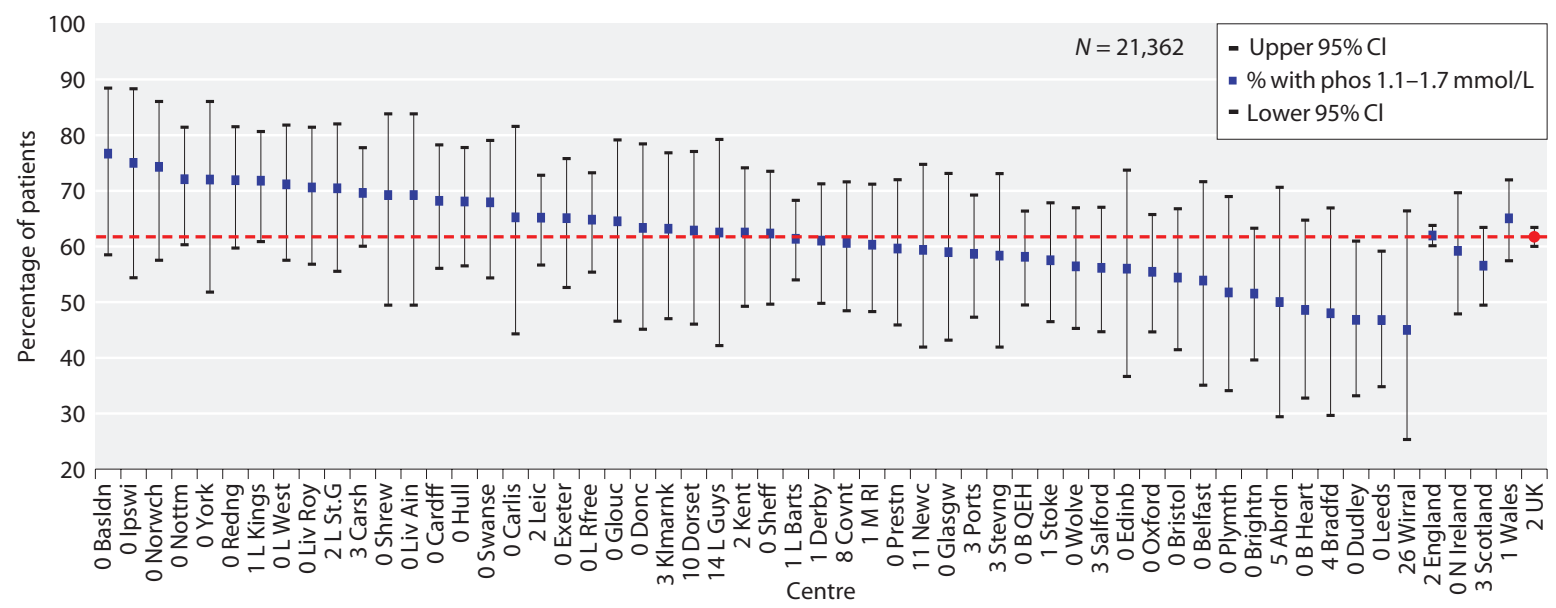

Fig. 8.3. Percentage of peritoneal dialysis patients with phosphate within the range specified by the RA clinical audit measure $(1.1-1.7 \mathrm{mmol} / \mathrm{L})$ by centre in 2013

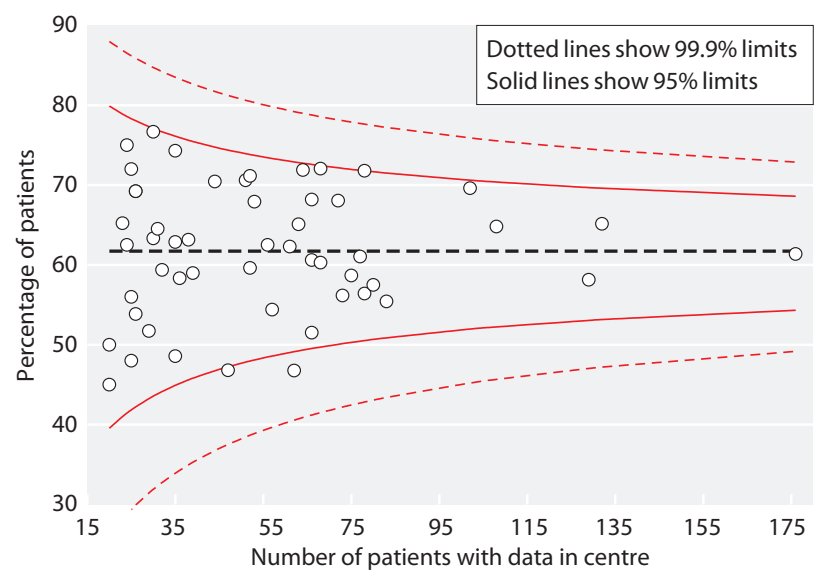

Fig. 8.4. Funnel plot of percentage of peritoneal dialysis patients with phosphate within the range specified by the RA clinical audit measure (1.1-1.7 $\mathrm{mmol} / \mathrm{L}$ ) by centre in 2013
Guideline 2.2 CKD-MBD: Serum calcium in dialysis patients (stage 5D)

'We suggest that serum calcium, adjusted for albumin concentration, should be maintained within the normal reference range for the laboratory used, measured before a "short-gap" dialysis session in haemodialysis patients. Ideally, adjusted serum calcium should be maintained between 2.2 and $2.5 \mathrm{mmol} / \mathrm{L}$, with avoidance of hypercalcaemic episodes (2D)' [3].

In 2013, the data for adjusted calcium was 97\% complete for HD patients and $98 \%$ complete for PD patients overall, although there was between centre variation (tables 8.7, 8.9). Seventy-eight percent (95\% CI $78-79 \%)$ of $\mathrm{HD}$ patients and $78 \%$ of PD (95\% CI

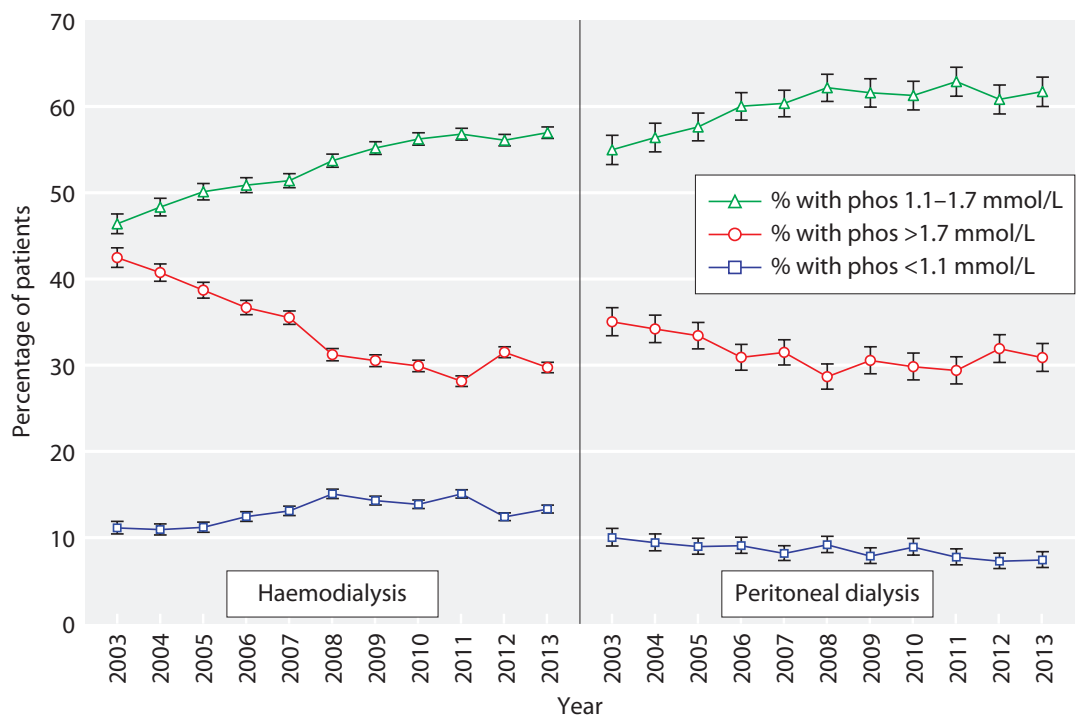

Fig. 8.5. Longitudinal change in percentage of patients with phosphate below, within and above the 2010 RA standard by dialysis modality 2003-2013 
Table 8.7. Summary statistics for adjusted calcium in haemodialysis patients in 2013

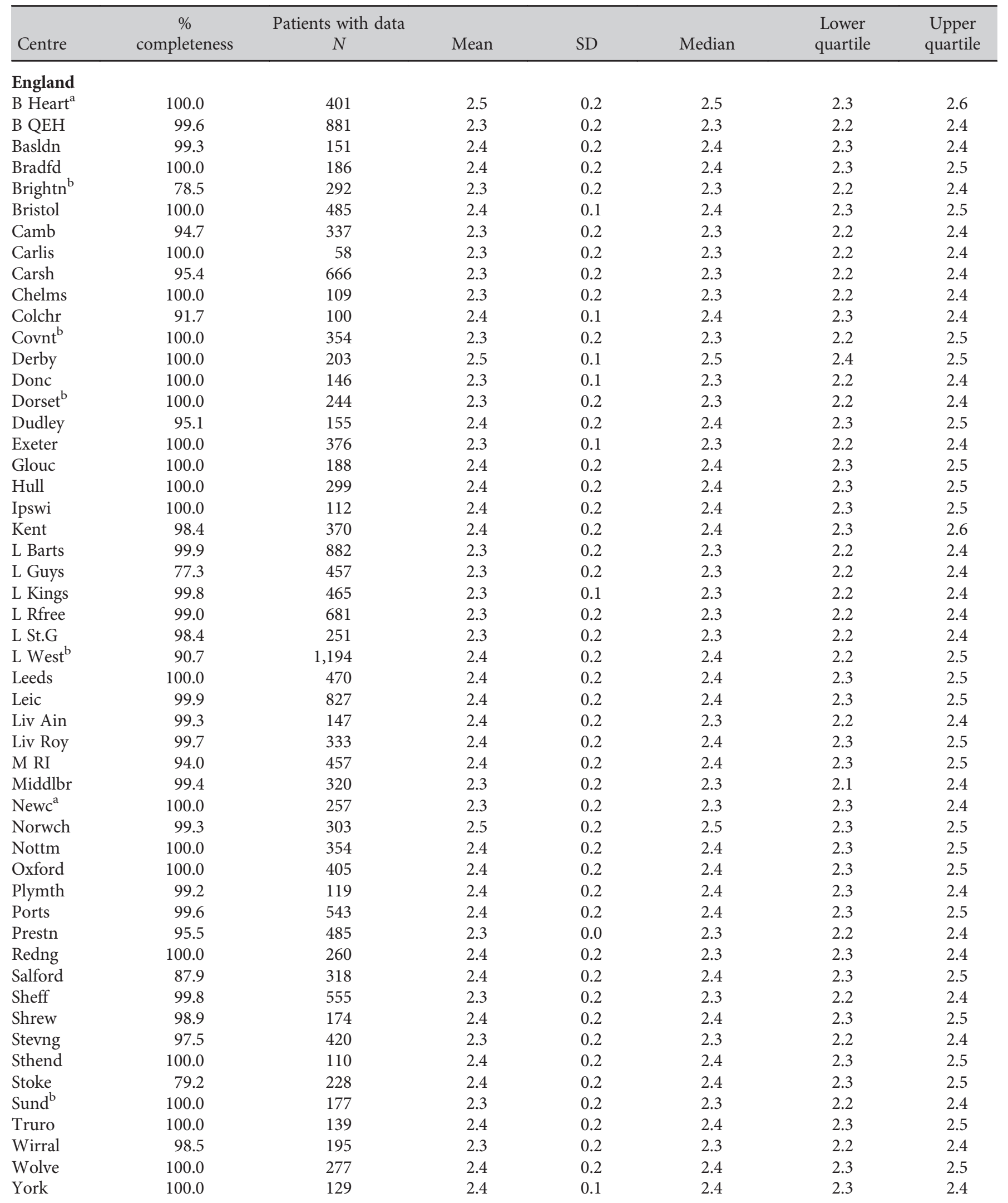


Table 8.7. Continued

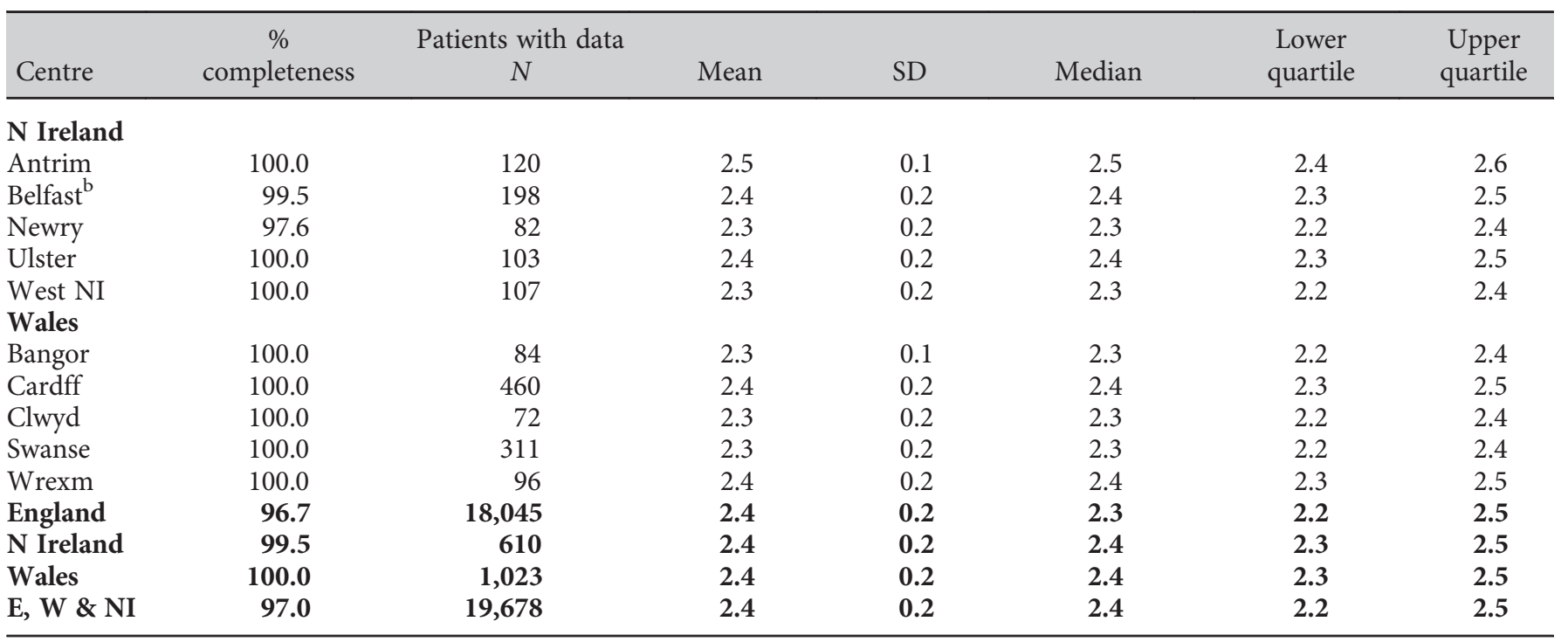

${ }^{a}$ Newcastle had a change in calcium assay in April 2013; Birmingham Heartlands had a change in calcium assay in 2012

${ }^{\mathrm{b}}$ These centres supplied uncorrected calcium and were corrected using the formula: adjusted calcium $=$ unadjusted calcium $+[(40$-albumin $) \times$ 0.02]

77-80\%) patients had an adjusted calcium between $2.2-$ $2.5 \mathrm{mmol} / \mathrm{L}$ (tables $8.8,8.10$ ). The proportion of $\mathrm{HD}$ patients with hypercalcaemia was $12 \%$ and the proportion with hypocalcaemia was $10 \%$. For PD patients the proportion of patients with hypercalcaemia was $15 \%$ and the proportion with hypocalcaemia was $7 \%$ (tables 8.8, 8.10, figures 8.6-8.9). Interestingly there was quite a large shift in the proportion of individuals on HD with an adjusted calcium greater than the target range in Northern Ireland when reviewed at aggregate level, with an increase from $9 \%$ to $14 \%$ between 2012 and 2013; corresponding changes in the proportion of patients with calcium $>2.5 \mathrm{mmol} / \mathrm{L}$ in Antrim and Belfast centres were observed. A reversal of this pattern was observed in the PD population with the suggestion of a fall in the proportion of patients in Northern Ireland with hypercalcaemia from $20 \%$ in 2012 to $13 \%$ in 2013. In Wales, there was an increase in the proportion of the PD population with hypercalcaemia from $10 \%$ in 2012 to $20 \%$ in 2013.

Similar to that seen in the earlier presented phosphate analyses, there was significant between centre variation in unadjusted analyses for the proportion of patients below, within and above the range specified by the clinical performance measure (figures 8.6-8.10). There was greater variation in the proportion of patients within range for adjusted calcium than phosphate, most notably for HD patients. The funnel plot shows a greater number

Management of biochemical variables of centres outlying the three standard deviation limit indicating over dispersion in the data, possibly due to differences in calcium adjustment factors between centres.

The changes in the percentages above, below and within range for the period 2003 to 2013 for England, Northern Ireland and Wales combined are shown in figure 8.10. The percentage of patients achieving the audit standard for calcium appears to have plateaued for both HD and PD patients in recent years. As with the phosphate data, this overall plateau masks substantial deterioration in a few centres achieving the standard this year (Carlisle, Antrim, Wrexham for HD patients; London West, Newcastle, Cardiff for PD patients) that has been countered by improvements in other centres.

\section{Parathyroid hormone}

At the beginning of 2013 the following RA guideline for PTH applied:

Guideline 4.2.1 CKD-MBD: Target range of serum $P T H$ in patients on dialysis

'We suggest that the target range for parathyroid hormone measured using an intact PTH assay should be between 2 and 9 times the upper limit of normal for the assay used (2C)' [3].

The data for parathyroid hormone were $93 \%$ complete for $\mathrm{HD}$ patients and $90 \%$ for $\mathrm{PD}$ patients overall,

Nephron 2015;129(suppl1):169-208 
Table 8.8. Percentage of haemodialysis patients within, below and above the range for adjusted calcium (2.2-2.5 mmol/L) in 2013

\begin{tabular}{|c|c|c|c|c|c|c|c|c|c|}
\hline Centre & $N$ & $\begin{array}{c}\% \text { adjusted } \mathrm{Ca} \\
2.2-2.5 \mathrm{mmol} / \mathrm{L}\end{array}$ & $\begin{array}{l}\text { Lower } \\
95 \% \text { CI }\end{array}$ & $\begin{array}{l}\text { Upper } \\
95 \% \mathrm{CI}\end{array}$ & $\begin{array}{l}\% \text { adjusted } \mathrm{Ca} \\
<2.2 \mathrm{mmol} / \mathrm{L}\end{array}$ & $\begin{array}{l}\% \text { adjusted } \mathrm{Ca} \\
>2.5 \mathrm{mmol} / \mathrm{L}\end{array}$ & $\begin{array}{l}\text { Change in } \% \\
\text { within range } \\
\text { from } 2012\end{array}$ & $\begin{array}{l}95 \% \\
\text { LCL } \\
\text { change }\end{array}$ & $\begin{array}{l}95 \% \\
\text { UCL } \\
\text { change }\end{array}$ \\
\hline \multicolumn{10}{|l|}{ England } \\
\hline B Heart ${ }^{\mathrm{a}}$ & 401 & 65.3 & 60.5 & 69.8 & 4.0 & 30.7 & 7.6 & 0.9 & 14.3 \\
\hline B QEH & 881 & 77.1 & 74.2 & 79.7 & 20.7 & 2.3 & 6.4 & 2.3 & 10.6 \\
\hline Basldn & 151 & 84.1 & 77.4 & 89.1 & 8.6 & 7.3 & 2.0 & -6.5 & 10.6 \\
\hline Bristol & 485 & 86.4 & 83.0 & 89.2 & 1.7 & 12.0 & 9.8 & 4.9 & 14.7 \\
\hline Camb & 337 & 82.2 & 77.7 & 85.9 & 11.0 & 6.8 & -4.8 & -10.4 & 0.7 \\
\hline Carlis & 58 & 65.5 & 52.5 & 76.6 & 24.1 & 10.3 & -13.4 & -29.6 & 2.7 \\
\hline Carsh & 666 & 80.9 & 77.8 & 83.7 & 11.9 & 7.2 & -0.6 & -4.8 & 3.7 \\
\hline Chelms & 109 & 88.1 & 80.5 & 93.0 & 5.5 & 6.4 & 3.8 & -5.1 & 12.7 \\
\hline Dorset $^{\mathrm{b}}$ & 244 & 82.4 & 77.1 & 86.7 & 8.6 & 9.0 & -2.4 & -9.0 & 4.2 \\
\hline Dudley & 155 & 80.7 & 73.7 & 86.1 & 8.4 & 11.0 & 2.4 & -6.7 & 11.4 \\
\hline Exeter & 376 & 88.3 & 84.6 & 91.2 & 3.2 & 8.5 & 12.6 & 7.0 & 18.1 \\
\hline Glouc & 188 & 81.9 & 75.8 & 86.8 & 5.3 & 12.8 & -4.7 & -12.0 & 2.6 \\
\hline Hull & 299 & 79.6 & 74.7 & 83.8 & 6.0 & 14.4 & 3.4 & -3.2 & 10.1 \\
\hline Ipswi & 112 & 76.8 & 68.1 & 83.7 & 6.3 & 17.0 & -3.1 & -13.6 & 7.5 \\
\hline Kent & 370 & 70.8 & 66.0 & 75.2 & 4.1 & 25.1 & 0.6 & -6.0 & 7.2 \\
\hline L Barts & 882 & 71.0 & 67.9 & 73.9 & 22.8 & 6.2 & 4.2 & -0.1 & 8.6 \\
\hline L Guys & 457 & 76.6 & 72.5 & 80.2 & 12.9 & 10.5 & 2.6 & -2.8 & 8.0 \\
\hline L Kings & 465 & 88.4 & 85.1 & 91.0 & 8.0 & 3.7 & 6.4 & 1.9 & 11.0 \\
\hline L Rfree & 681 & 85.8 & 82.9 & 88.2 & 9.5 & 4.7 & 9.2 & 4.8 & 13.6 \\
\hline L St.G & 251 & 78.9 & 73.4 & 83.5 & 13.2 & 8.0 & -2.0 & -8.9 & 5.0 \\
\hline Newc ${ }^{\mathrm{a}}$ & 257 & 87.9 & 83.4 & 91.4 & 7.8 & 4.3 & 12.8 & 6.2 & 19.3 \\
\hline Norwch & 303 & 72.3 & 67.0 & 77.0 & 3.3 & 24.4 & 2.5 & -4.7 & 9.8 \\
\hline Nottm & 354 & 78.0 & 73.4 & 82.0 & 5.7 & 16.4 & -5.1 & -10.9 & 0.7 \\
\hline Oxford & 405 & 80.3 & 76.1 & 83.8 & 8.2 & 11.6 & 1.3 & -4.3 & 6.9 \\
\hline Plymth & 119 & 77.3 & 68.9 & 84.0 & 10.9 & 11.8 & -10.1 & -19.7 & -0.5 \\
\hline Ports & 543 & 78.6 & 75.0 & 81.9 & 7.0 & 14.4 & -1.3 & -6.2 & 3.6 \\
\hline Prestn & 485 & 79.0 & 75.1 & 82.4 & 17.1 & 3.9 & 3.9 & -1.4 & 9.1 \\
\hline Redng & 260 & 84.2 & 79.3 & 88.2 & 7.3 & 8.5 & 3.8 & -2.9 & 10.4 \\
\hline Salford & 318 & 79.9 & 75.1 & 83.9 & 8.2 & 12.0 & 8.4 & 1.7 & 15.1 \\
\hline Sheff & 555 & 79.8 & 76.3 & 83.0 & 15.3 & 4.9 & 2.1 & -2.7 & 6.9 \\
\hline Shrew & 174 & 82.2 & 75.8 & 87.2 & 7.5 & 10.3 & 10.4 & 1.8 & 19.1 \\
\hline Stevng & 420 & 81.9 & 77.9 & 85.3 & 10.7 & 7.4 & 1.9 & -3.6 & 7.3 \\
\hline Sthend & 110 & 71.8 & 62.7 & 79.4 & 7.3 & 20.9 & -5.0 & -16.6 & 6.5 \\
\hline Stoke & 228 & 83.3 & 77.9 & 87.6 & 4.8 & 11.8 & 5.1 & -2.0 & 12.2 \\
\hline Sund $^{\mathrm{b}}$ & 177 & 74.6 & 67.7 & 80.5 & 16.4 & 9.0 & -2.5 & -11.3 & 6.4 \\
\hline Truro & 139 & 81.3 & 73.9 & 86.9 & 5.0 & 13.7 & 7.6 & -2.3 & 17.5 \\
\hline Wirral & 195 & 84.1 & 78.3 & 88.6 & 10.8 & 5.1 & 2.7 & -5.2 & 10.5 \\
\hline Wolve & 277 & 77.3 & 72.0 & 81.8 & 6.5 & 16.3 & 0.8 & -6.3 & 7.8 \\
\hline York & 129 & 92.3 & 86.2 & 95.8 & 1.6 & 6.2 & 1.3 & -5.6 & 8.2 \\
\hline
\end{tabular}


Table 8.8. Continued

\begin{tabular}{|c|c|c|c|c|c|c|c|c|c|}
\hline Centre & $N$ & $\begin{array}{c}\% \text { adjusted } \mathrm{Ca} \\
2.2-2.5 \mathrm{mmol} / \mathrm{L}\end{array}$ & $\begin{array}{l}\text { Lower } \\
95 \% \mathrm{CI}\end{array}$ & $\begin{array}{l}\text { Upper } \\
95 \% \text { CI }\end{array}$ & $\begin{array}{l}\% \text { adjusted } \mathrm{Ca} \\
<2.2 \mathrm{mmol} / \mathrm{L}\end{array}$ & $\begin{array}{l}\% \text { adjusted } \mathrm{Ca} \\
>2.5 \mathrm{mmol} / \mathrm{L}\end{array}$ & $\begin{array}{l}\text { Change in } \% \\
\text { within range } \\
\text { from } 2012\end{array}$ & $\begin{array}{l}\text { 95\% } \\
\text { LCL } \\
\text { change }\end{array}$ & $\begin{array}{c}95 \% \\
\text { UCL } \\
\text { change }\end{array}$ \\
\hline \multicolumn{10}{|l|}{ N Ireland } \\
\hline Antrim & 120 & 69.2 & 60.4 & 76.8 & 1.7 & 29.2 & -14.8 & -25.3 & -4.4 \\
\hline Belfast $^{\mathrm{b}}$ & 198 & 76.8 & 70.4 & 82.1 & 9.6 & 13.6 & -5.7 & -13.5 & 2.2 \\
\hline Newry & 82 & 84.2 & 74.6 & 90.6 & 12.2 & 3.7 & -0.6 & -11.6 & 10.4 \\
\hline Ulster & 103 & 82.5 & 74.0 & 88.7 & 2.9 & 14.6 & 1.3 & -9.2 & 11.9 \\
\hline West NI & 107 & 81.3 & 72.8 & 87.6 & 12.2 & 6.5 & -2.4 & -12.2 & 7.3 \\
\hline \multicolumn{10}{|l|}{ Wales } \\
\hline Bangor & 84 & 85.7 & 76.5 & 91.7 & 11.9 & 2.4 & 2.8 & -8.3 & 13.8 \\
\hline Cardff & 460 & 71.1 & 66.8 & 75.1 & 8.5 & 20.4 & -2.1 & -7.9 & 3.8 \\
\hline Clwyd & 72 & 83.3 & 72.9 & 90.3 & 15.3 & 1.4 & 9.6 & -3.5 & 22.8 \\
\hline Swanse & 311 & 72.4 & 67.1 & 77.0 & 14.5 & 13.2 & -3.1 & -10.0 & 3.8 \\
\hline Wrexm & 96 & 75.0 & 65.4 & 82.6 & 5.2 & 19.8 & -13.5 & -24.5 & -2.6 \\
\hline England & 18,045 & 78.5 & 77.9 & 79.1 & 10.3 & 11.2 & 2.0 & 1.1 & 2.8 \\
\hline N Ireland & 610 & 78.0 & 74.6 & 81.1 & 7.7 & 14.3 & -5.1 & -9.4 & -0.7 \\
\hline Wales & 1,023 & 73.9 & 71.1 & 76.5 & 10.8 & 15.4 & -2.1 & -5.9 & 1.6 \\
\hline $\mathrm{E}, \mathrm{W} \& \mathrm{NI}$ & 19,678 & 78.2 & 77.7 & 78.8 & 10.2 & 11.6 & 1.5 & 0.7 & 2.3 \\
\hline
\end{tabular}

${ }^{a}$ Newcastle had a change in calcium assay in April 2013; Birmingham Heartlands had a change in calcium assay in 2012

${ }^{\mathrm{b}}$ These centres supplied uncorrected calcium and were corrected using the formula: adjusted calcium $=$ unadjusted calcium $+[(40$-albumin $) \times$ 0.02]

Table 8.9. Summary statistics for adjusted calcium in peritoneal dialysis patients in 2013

\begin{tabular}{|c|c|c|c|c|c|c|c|}
\hline Centre & $\begin{array}{c}\% \\
\text { completeness }\end{array}$ & $\begin{array}{c}\text { Patients with data } \\
\qquad N\end{array}$ & Mean & SD & Median & $\begin{array}{l}\text { Lower } \\
\text { quartile }\end{array}$ & $\begin{array}{l}\text { Upper } \\
\text { quartile }\end{array}$ \\
\hline \multicolumn{8}{|l|}{ England } \\
\hline B QEH & 100.0 & 129 & 2.3 & 0.2 & 2.3 & 2.2 & 2.4 \\
\hline Basldn & 100.0 & 30 & 2.4 & 0.1 & 2.4 & 2.3 & 2.5 \\
\hline Bradfd & 96.2 & 25 & 2.5 & 0.1 & 2.4 & 2.4 & 2.5 \\
\hline Bristol & 100.0 & 57 & 2.4 & 0.2 & 2.4 & 2.3 & 2.5 \\
\hline Camb & 94.7 & 18 & & & & & \\
\hline Carlis & 100.0 & 23 & 2.3 & 0.2 & 2.3 & 2.2 & 2.4 \\
\hline Carsh & 97.1 & 102 & 2.4 & 0.2 & 2.4 & 2.3 & 2.5 \\
\hline Chelms & 95.0 & 19 & & & & & \\
\hline \multicolumn{8}{|l|}{ Colchr ${ }^{c}$} \\
\hline Dudley & 100.0 & 47 & 2.4 & 0.2 & 2.4 & 2.3 & 2.5 \\
\hline Exeter & 100.0 & 63 & 2.4 & 0.1 & 2.4 & 2.3 & 2.4 \\
\hline Glouc & 100.0 & 31 & 2.4 & 0.1 & 2.4 & 2.3 & 2.4 \\
\hline Hull & 100.0 & 72 & 2.4 & 0.2 & 2.4 & 2.3 & 2.5 \\
\hline Ipswi & 100.0 & 24 & 2.3 & 0.2 & 2.4 & 2.2 & 2.4 \\
\hline Kent & 98.3 & 56 & 2.5 & 0.2 & 2.5 & 2.4 & 2.6 \\
\hline L Barts & 98.9 & 176 & 2.3 & 0.2 & 2.3 & 2.2 & 2.5 \\
\hline
\end{tabular}


Table 8.9. Continued

\begin{tabular}{|c|c|c|c|c|c|c|c|}
\hline Centre & $\begin{array}{c}\% \\
\text { completeness }\end{array}$ & $\begin{array}{c}\text { Patients with data } \\
\qquad N\end{array}$ & Mean & SD & Median & $\begin{array}{l}\text { Lower } \\
\text { quartile }\end{array}$ & $\begin{array}{l}\text { Upper } \\
\text { quartile }\end{array}$ \\
\hline L Guys & 85.7 & 24 & 2.3 & 0.2 & 2.3 & 2.3 & 2.4 \\
\hline L Rfree & 100.0 & 108 & 2.4 & 0.2 & 2.3 & 2.3 & 2.5 \\
\hline L St.G & 100.0 & 45 & 2.5 & 0.1 & 2.5 & 2.4 & 2.5 \\
\hline $\mathrm{L} \mathrm{West}^{\mathrm{b}}$ & 100.0 & 52 & 2.5 & 0.2 & 2.6 & 2.5 & 2.7 \\
\hline Leic & 97.8 & 132 & 2.4 & 0.2 & 2.4 & 2.3 & 2.5 \\
\hline Liv Ain & 100.0 & 26 & 2.4 & 0.2 & 2.3 & 2.2 & 2.4 \\
\hline Liv Roy & 100.0 & 51 & 2.4 & 0.1 & 2.4 & 2.3 & 2.5 \\
\hline M RI & 98.6 & 68 & 2.4 & 0.2 & 2.4 & 2.3 & 2.5 \\
\hline Middlbr & 100.0 & 11 & & & & & \\
\hline Newc $^{\mathrm{a}}$ & 88.9 & 32 & 2.4 & 0.2 & 2.4 & 2.3 & 2.5 \\
\hline Plymth & 100.0 & 29 & 2.4 & 0.1 & 2.4 & 2.4 & 2.5 \\
\hline Ports & 97.4 & 75 & 2.4 & 0.1 & 2.4 & 2.3 & 2.5 \\
\hline Prestn & 100.0 & 52 & 2.3 & 0.2 & 2.3 & 2.2 & 2.4 \\
\hline Redng & 100.0 & 64 & 2.4 & 0.1 & 2.4 & 2.3 & 2.5 \\
\hline Salford & 97.3 & 73 & 2.4 & 0.2 & 2.4 & 2.3 & 2.5 \\
\hline Sheff & 100.0 & 61 & 2.3 & 0.2 & 2.3 & 2.2 & 2.4 \\
\hline Shrew & 100.0 & 26 & 2.4 & 0.2 & 2.4 & 2.3 & 2.5 \\
\hline Stevng & 100.0 & 37 & 2.4 & 0.1 & 2.4 & 2.3 & 2.4 \\
\hline Sthend & 100.0 & 15 & & & & & \\
\hline Stoke & 87.7 & 71 & 2.4 & 0.2 & 2.4 & 2.3 & 2.6 \\
\hline Sund $^{\mathrm{b}}$ & 100.0 & 8 & & & & & \\
\hline Newry & 100.0 & 17 & & & & & \\
\hline Ulster & 100.0 & 4 & & & & & \\
\hline West NI & 100.0 & 14 & & & & & \\
\hline \multicolumn{8}{|l|}{ Wales } \\
\hline Bangor & 100.0 & 12 & & & & & \\
\hline Cardff & 100.0 & 66 & 2.5 & 0.2 & 2.5 & 2.4 & 2.6 \\
\hline Clwyd & 100.0 & 14 & & & & & \\
\hline Swanse & 100.0 & 53 & 2.3 & 0.2 & 2.3 & 2.2 & 2.4 \\
\hline Wrexm & 94.7 & 18 & & & & & \\
\hline England & 98.3 & 2,715 & 2.4 & 0.2 & 2.4 & 2.3 & 2.5 \\
\hline N Ireland & 98.7 & 75 & 2.4 & 0.2 & 2.3 & 2.3 & 2.5 \\
\hline Wales & 99.4 & 163 & 2.4 & 0.2 & 2.4 & 2.3 & 2.5 \\
\hline $\mathrm{E}, \mathrm{W} \& \mathrm{NI}$ & 98.4 & 2,953 & 2.4 & 0.2 & 2.4 & 2.3 & 2.5 \\
\hline
\end{tabular}

Blank cells: centres excluded from the analysis due to low patient numbers

${ }^{a}$ Newcastle had a change in calcium assay in April 2013; Birmingham Heartlands had a change in calcium assay in 2012

${ }^{b}$ These centres supplied uncorrected calcium and were corrected using the formula: adjusted calcium $=$ unadjusted calcium $+[(40$-albumin $) \times$ 0.02]

${ }^{\mathrm{c}}$ No PD patients 
Table 8.10. Percentage of peritoneal dialysis patients within, below and above the range for adjusted calcium (2.2-2.5 mmol/L) in 2013

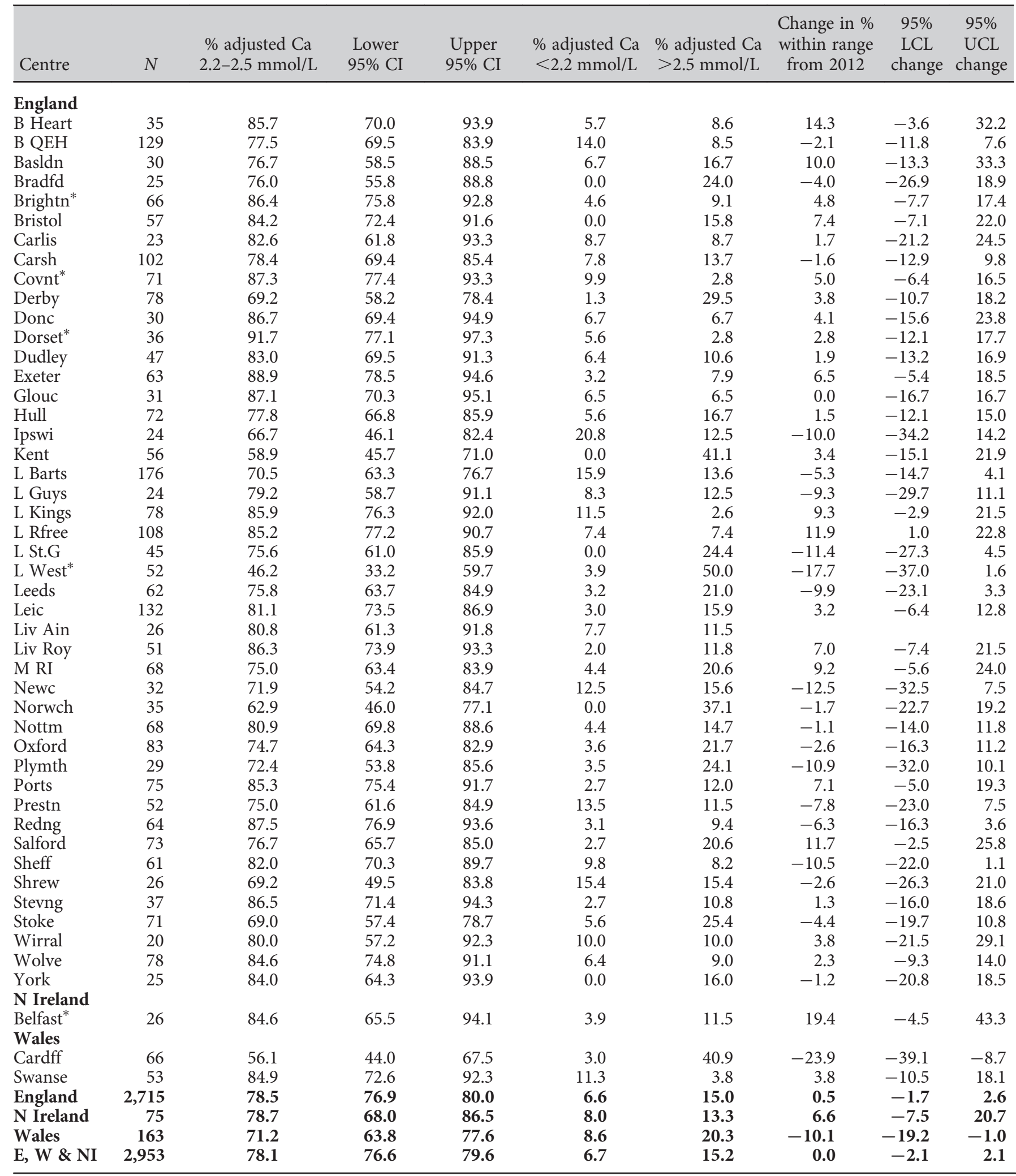

${ }^{*}$ These centres supplied uncorrected calcium and were corrected using the formula: adjusted calcium $=$ unadjusted calcium $+[(40$-albumin $) \times$ $0.02]$ 


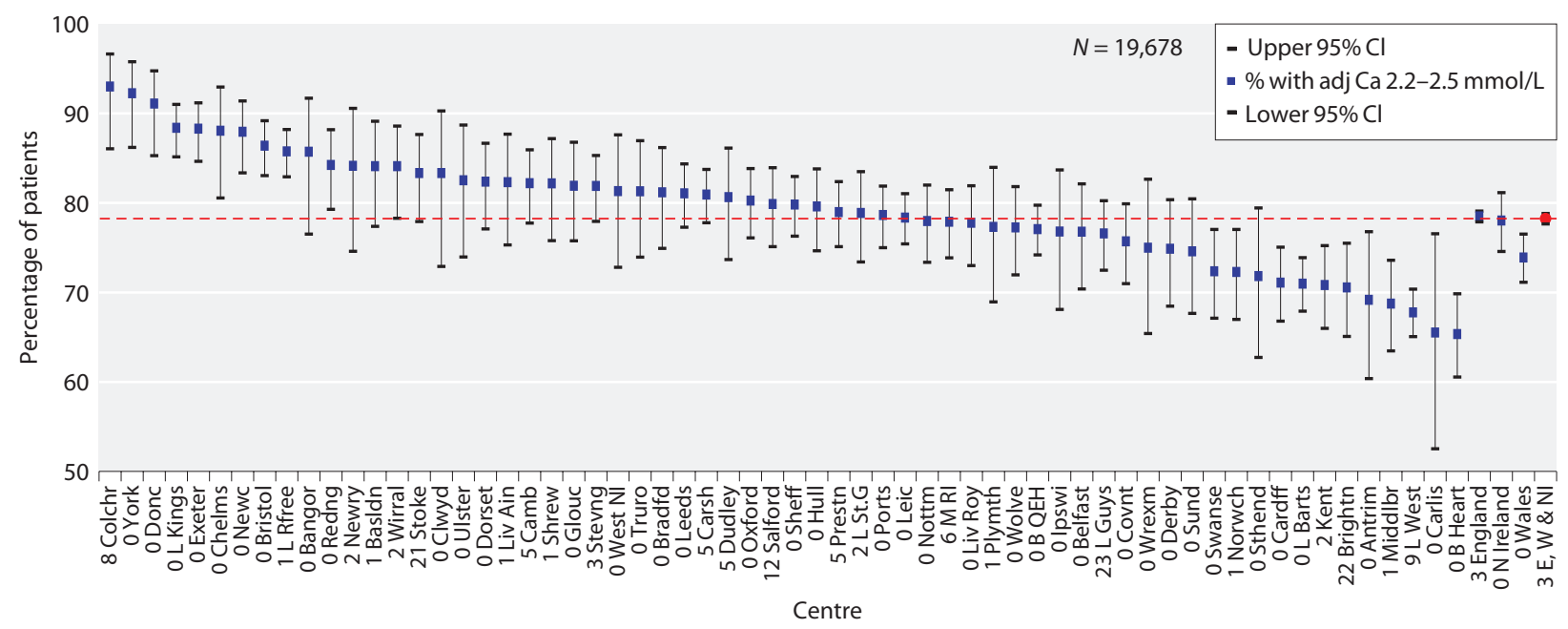

Fig. 8.6. Percentage of haemodialysis patients with adjusted calcium within range $(2.2-2.5 \mathrm{mmol} / \mathrm{L})$ by centre in 2013

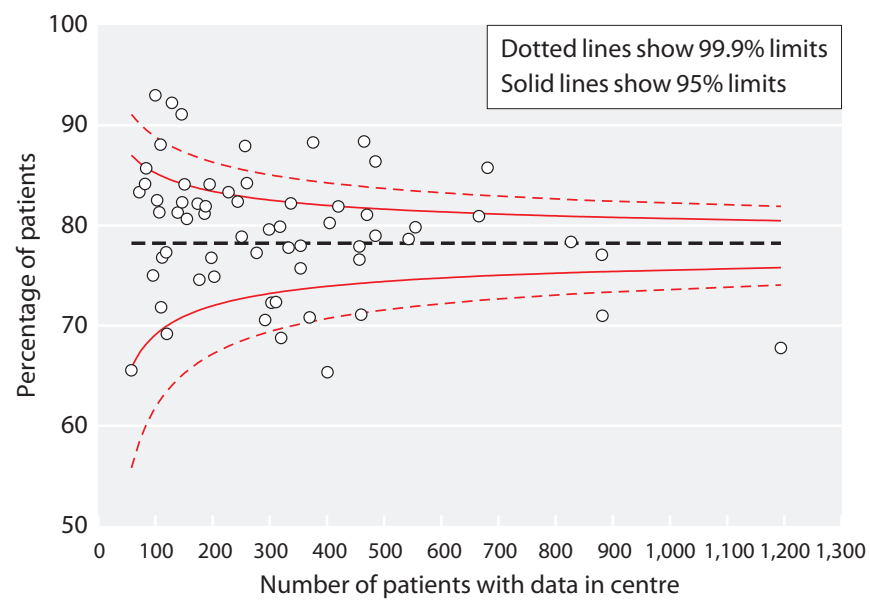

Fig. 8.7. Funnel plot of percentage of haemodialysis patients with adjusted calcium within range $(2.2-2.5 \mathrm{mmol} / \mathrm{L})$ by centre in 2013

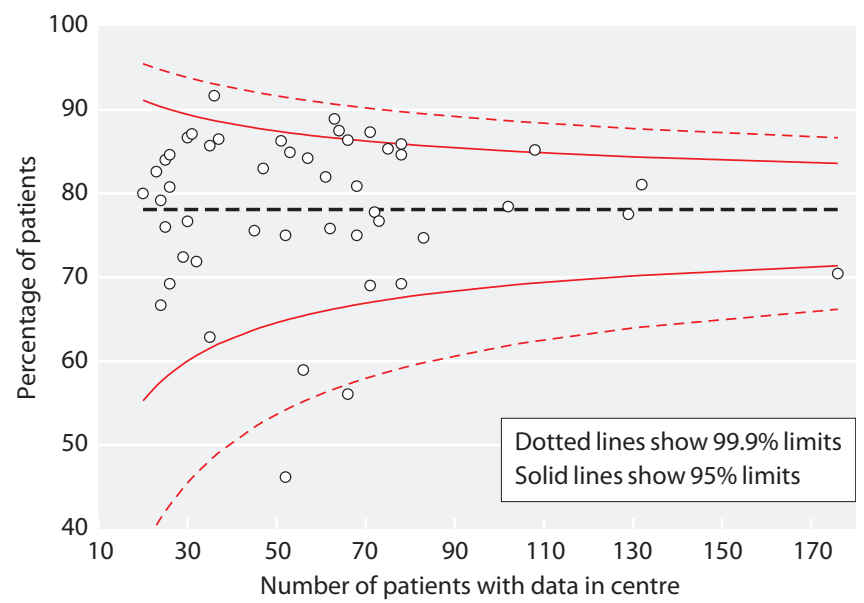

Fig. 8.9. Funnel plot of percentage of peritoneal dialysis patients with adjusted calcium within range $(2.2-2.5 \mathrm{mmol} / \mathrm{L})$ by centre in 2013

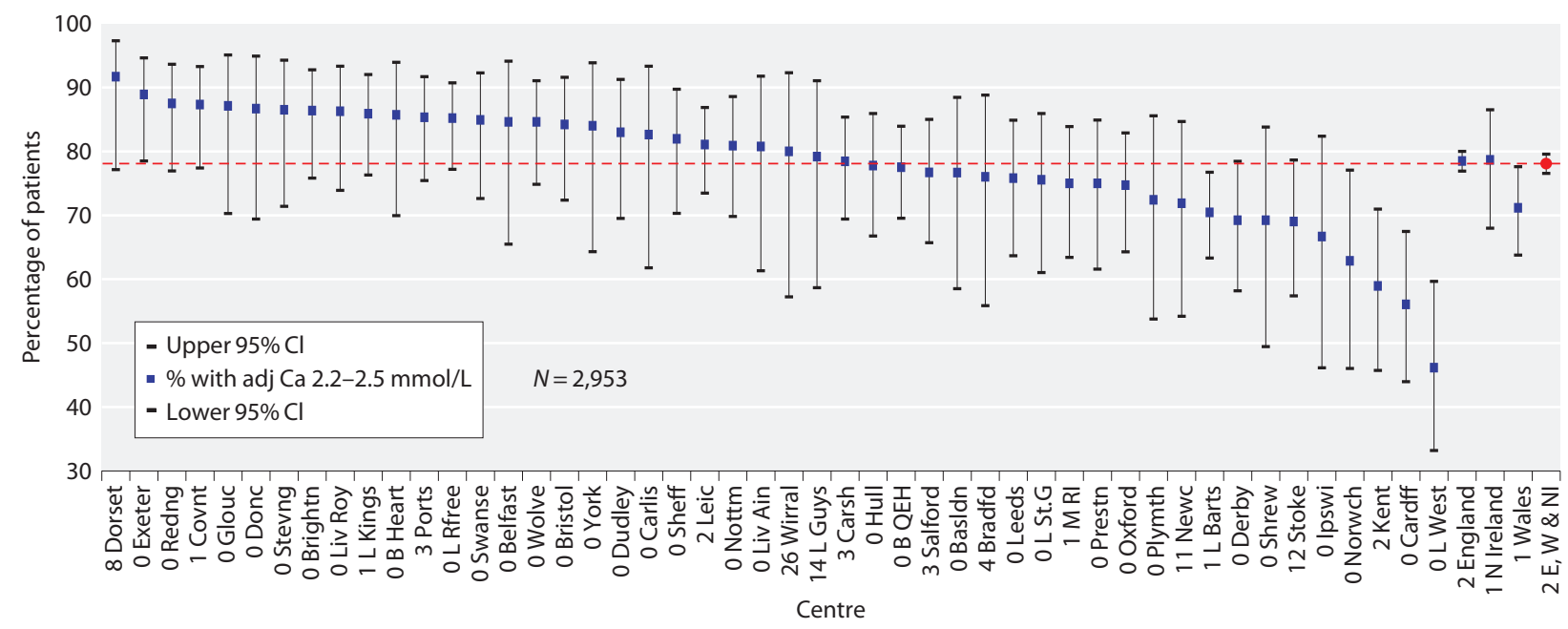

Fig. 8.8. Percentage of peritoneal dialysis patients with adjusted calcium within range $(2.2-2.5 \mathrm{mmol} / \mathrm{L})$ by centre in 2013 


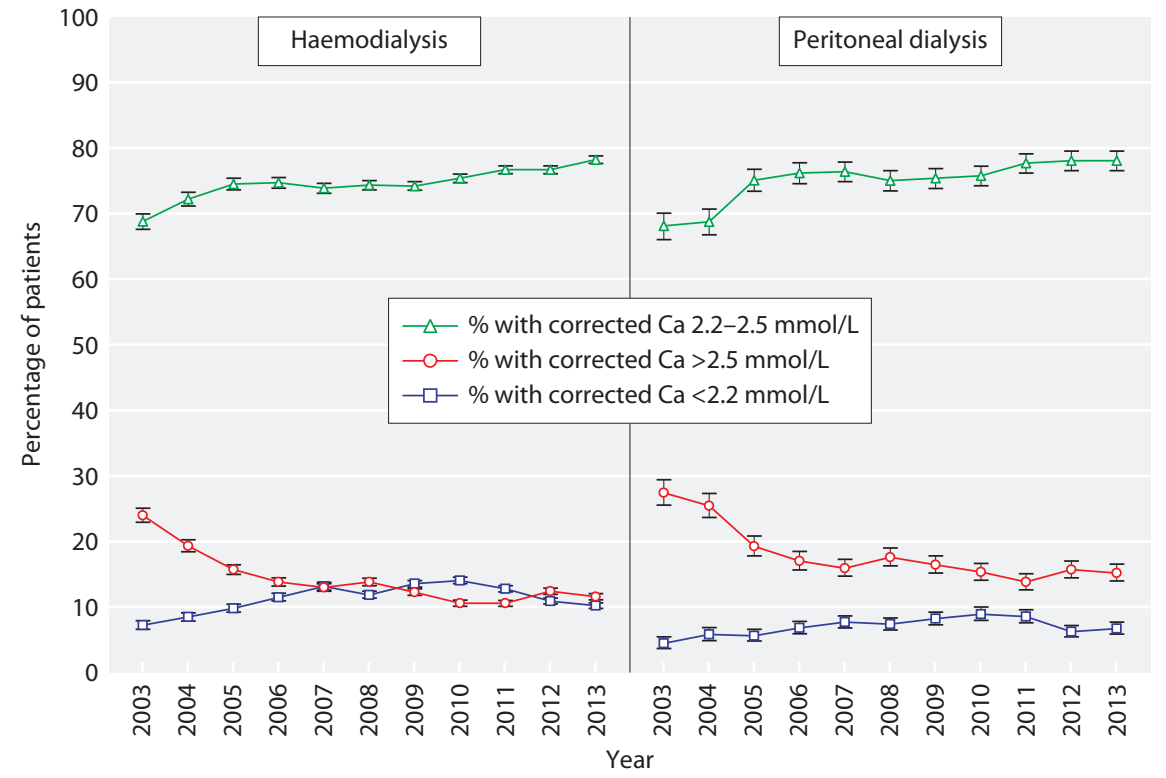

Fig. 8.10. Longitudinal change in percentage of patients with adjusted calcium $<2.2 \mathrm{mmol} / \mathrm{L}, 2.2-2.5 \mathrm{mmol} / \mathrm{L}$ and $>2.5 \mathrm{mmol} / \mathrm{L}$ by dialysis modality 2003-2013 although there was between centre variation (tables 8.11, 8.13). Fifty-seven percent (95\% CI 56-58\%) of HD patients and 63\% (95\% CI 61-65\%) of PD patients achieved a parathyroid hormone between $16-72 \mathrm{pmol} / \mathrm{L}$ (tables 8.12, 8.14).

In 2013 , the proportion of HD patients with a parathyroid hormone above the upper limit of the range $(>72 \mathrm{pmol} / \mathrm{L})$ was $17 \%$ and the proportion with parathyroid hormone below the lower limit of the range was $26 \%$, very similar to aggregate level results in 2012 . The proportion of $\mathrm{PD}$ patients with parathyroid hormone above the upper limit of the range was $13 \%$ and the proportion below the lower limit of the range was $24 \%$ (tables 8.12, 8.14, figures 8.11-8.14). Again there was significant between centre variation in unadjusted analyses for the proportion of patients below, within and above the range specified by the clinical performance measure.

There was no substantial variation in attainment of the standard for HD patients but there was deterioration for some PD centres (Birmingham Heartlands, Basildon, Newcastle, Portsmouth) where increases in patients both below and above the audit range were seen.

Table 8.11. Summary statistics for PTH in haemodialysis patients in 2013

\begin{tabular}{|c|c|c|c|c|c|c|c|}
\hline Centre & $\begin{array}{c}\% \\
\text { completeness }\end{array}$ & $\begin{array}{c}\text { Patients with data } \\
\qquad N\end{array}$ & Mean & SD & Median & $\begin{array}{l}\text { Lower } \\
\text { quartile }\end{array}$ & $\begin{array}{l}\text { Upper } \\
\text { quartile }\end{array}$ \\
\hline \multicolumn{8}{|l|}{ England } \\
\hline B Heart & 100.0 & 401 & 61.8 & 51.9 & 49 & 26 & 80 \\
\hline B QEH & 93.6 & 828 & 43.8 & 51.3 & 29 & 15 & 53 \\
\hline Basldn & 98.0 & 149 & 38.0 & 31.9 & 30 & 17 & 49 \\
\hline Bradfd & 98.9 & 184 & 35.3 & 37.5 & 21 & 12 & 48 \\
\hline Brightn & 81.2 & 302 & 39.0 & 45.8 & 26 & 13 & 49 \\
\hline Bristol & 98.6 & 478 & 37.7 & 44.2 & 26 & 12 & 45 \\
\hline Camb & 73.9 & 263 & 28.1 & 29.2 & 23 & 11 & 36 \\
\hline Carlis & 98.3 & 57 & 29.9 & 30.3 & 22 & 12 & 32 \\
\hline Carsh & 74.6 & 521 & 60.4 & 58.2 & 41 & 23 & 77 \\
\hline Chelms & 100.0 & 109 & 42.0 & 29.7 & 33 & 20 & 52 \\
\hline Colchr & 89.9 & 98 & 25.6 & 28.4 & 18 & 9 & 27 \\
\hline Covnt & 98.0 & 347 & 43.9 & 46.0 & 28 & 15 & 56 \\
\hline Derby & 99.5 & 202 & 30.5 & 24.4 & 24 & 16 & 39 \\
\hline Donc & 100.0 & 146 & 49.3 & 39.9 & 40 & 26 & 63 \\
\hline Dorset & 98.8 & 241 & 28.3 & 28.3 & 19 & 10 & 37 \\
\hline Dudley & 90.2 & 147 & 37.5 & 40.0 & 27 & 13 & 46 \\
\hline Exeter & 98.9 & 372 & 22.6 & 25.3 & 15 & 7 & 28 \\
\hline
\end{tabular}


Table 8.11. Continued

\begin{tabular}{|c|c|c|c|c|c|c|c|}
\hline Centre & $\begin{array}{c}\% \\
\text { completeness }\end{array}$ & $\begin{array}{c}\text { Patients with data } \\
\qquad N\end{array}$ & Mean & $\mathrm{SD}$ & Median & $\begin{array}{l}\text { Lower } \\
\text { quartile }\end{array}$ & $\begin{array}{l}\text { Upper } \\
\text { quartile }\end{array}$ \\
\hline Glouc & 99.5 & 187 & 34.3 & 34.1 & 27 & 14 & 45 \\
\hline Hull & 97.3 & 291 & 49.4 & 53.9 & 31 & 15 & 65 \\
\hline Ipswi & 100.0 & 112 & 30.5 & 38.0 & 19 & 12 & 32 \\
\hline Kent & 98.9 & 372 & 48.4 & 40.1 & 38 & 19 & 57 \\
\hline L Barts & 99.1 & 875 & 51.7 & 52.9 & 37 & 18 & 67 \\
\hline L Guys & 72.8 & 430 & 50.8 & 51.3 & 36 & 15 & 73 \\
\hline L Kings & 98.7 & 460 & 44.9 & 45.1 & 31 & 13 & 59 \\
\hline L Rfree & 98.4 & 677 & 45.7 & 45.0 & 34 & 17 & 59 \\
\hline L St.G & 94.9 & 242 & 55.5 & 53.3 & 40 & 20 & 72 \\
\hline L West & 81.4 & 1,072 & 64.0 & 63.5 & 44 & 21 & 83 \\
\hline Leeds & 96.8 & 455 & 40.4 & 40.3 & 27 & 13 & 54 \\
\hline Leic & 98.6 & 816 & 40.9 & 41.8 & 27 & 11 & 59 \\
\hline Liv Ain & 98.0 & 145 & 23.4 & 26.6 & 14 & 6 & 34 \\
\hline Liv Roy & 99.7 & 333 & 38.0 & 39.2 & 25 & 12 & 48 \\
\hline M RI & 83.7 & 407 & 50.1 & 45.6 & 38 & 19 & 66 \\
\hline Middlbr & 94.4 & 304 & 50.5 & 47.4 & 38 & 20 & 64 \\
\hline Newc & 99.6 & 256 & 41.5 & 36.4 & 31 & 16 & 55 \\
\hline Norwch & 97.7 & 298 & 38.2 & 33.4 & 30 & 15 & 51 \\
\hline Nottm & 100.0 & 354 & 43.9 & 51.6 & 30 & 15 & 52 \\
\hline Oxford & 99.0 & 401 & 44.4 & 38.4 & 34 & 16 & 60 \\
\hline Plymth & 96.7 & 116 & 35.4 & 46.5 & 24 & 12 & 39 \\
\hline Ports & 84.8 & 462 & 45.9 & 46.5 & 32 & 16 & 57 \\
\hline Prestn & 99.4 & 505 & 42.4 & 42.6 & 28 & 15 & 55 \\
\hline Redng & 100.0 & 260 & 38.5 & 35.2 & 32 & 16 & 49 \\
\hline Salford & 82.9 & 300 & 29.9 & 28.4 & 21 & 10 & 40 \\
\hline Sheff & 99.1 & 551 & 44.0 & 43.7 & 32 & 16 & 56 \\
\hline Shrew & 99.4 & 175 & 30.5 & 33.2 & 19 & 10 & 38 \\
\hline Stevng & 95.4 & 411 & 42.1 & 31.9 & 38 & 19 & 57 \\
\hline Sthend & 90.0 & 99 & 44.5 & 40.7 & 31 & 19 & 56 \\
\hline Stoke & 76.7 & 221 & 44.0 & 35.3 & 35 & 19 & 59 \\
\hline Sund & 99.4 & 176 & 41.0 & 39.3 & 29 & 12 & 60 \\
\hline Truro & 99.3 & 138 & 22.4 & 28.0 & 14 & 6 & 29 \\
\hline Wirral & 98.5 & 195 & 31.5 & 28.6 & 26 & 14 & 43 \\
\hline Wolve & 93.9 & 260 & 45.1 & 46.9 & 32 & 15 & 57 \\
\hline York & 95.4 & 123 & 28.0 & 32.9 & 18 & 7 & 40 \\
\hline \multicolumn{8}{|l|}{$\mathrm{N}$ Ireland } \\
\hline Antrim & 100.0 & 120 & 28.2 & 29.6 & 20 & 14 & 35 \\
\hline Belfast & 98.5 & 196 & 36.1 & 39.4 & 23 & 12 & 47 \\
\hline Newry & 100.0 & 84 & 28.6 & 21.9 & 22 & 12 & 42 \\
\hline Ulster & 99.0 & 102 & 23.7 & 22.0 & 16 & 8 & 32 \\
\hline West NI & 100.0 & 107 & 33.4 & 22.3 & 30 & 18 & 41 \\
\hline \multicolumn{8}{|l|}{ Wales } \\
\hline Bangor & 98.8 & 83 & 26.3 & 20.3 & 23 & 14 & 33 \\
\hline Cardff & 98.0 & 451 & 43.9 & 38.0 & 34 & 19 & 56 \\
\hline Clwyd & 100.0 & 72 & 40.4 & 39.8 & 30 & 13 & 54 \\
\hline Swanse & 74.0 & 230 & 39.3 & 37.5 & 32 & 16 & 53 \\
\hline Wrexm & 96.9 & 93 & 21.7 & 18.2 & 19 & 10 & 29 \\
\hline England & 92.9 & 17,324 & 43.9 & 45.7 & 30 & 15 & 57 \\
\hline N Ireland & 99.4 & 609 & 30.9 & 30.4 & 22 & 12 & 39 \\
\hline Wales & 90.8 & 929 & 38.7 & 36.0 & 30 & 16 & 51 \\
\hline E, W \& NI & 93.0 & 18,862 & 43.2 & 44.9 & 30 & 15 & 56 \\
\hline
\end{tabular}


Table 8.12. Percentage of haemodialysis patients within, below and above the range for PTH (16-72 pmol/L) in 2013

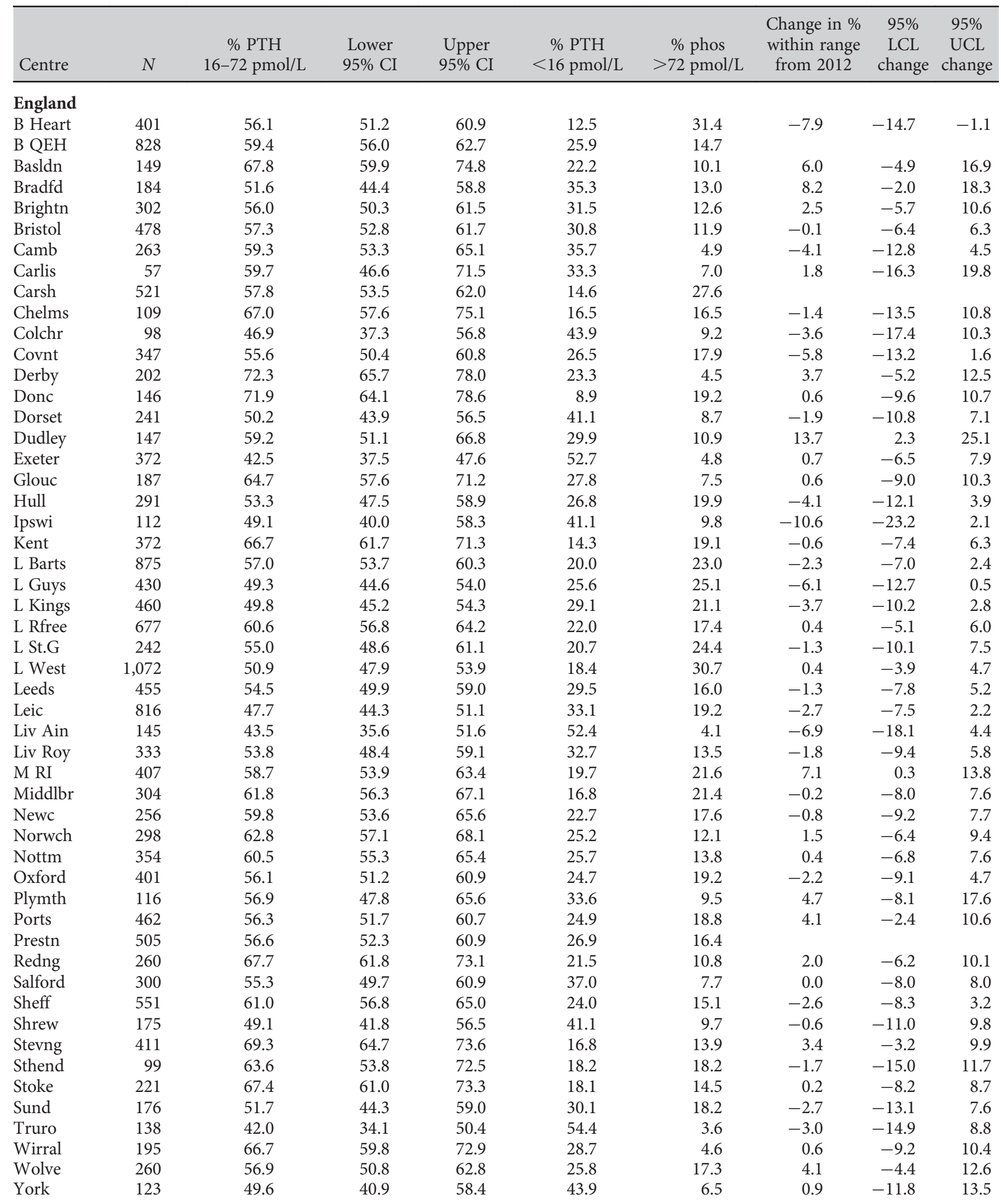


Table 8.12. Continued

\begin{tabular}{|c|c|c|c|c|c|c|c|c|c|}
\hline Centre & $N$ & $\begin{array}{c}\text { \% PTH } \\
16-72 \mathrm{pmol} / \mathrm{L}\end{array}$ & $\begin{array}{l}\text { Lower } \\
95 \% \text { CI }\end{array}$ & $\begin{array}{l}\text { Upper } \\
95 \% \text { CI }\end{array}$ & $\begin{array}{c}\% \mathrm{PTH} \\
<16 \mathrm{pmol} / \mathrm{L}\end{array}$ & $\begin{array}{c}\% \mathrm{phos} \\
>72 \mathrm{pmol} / \mathrm{L}\end{array}$ & $\begin{array}{l}\text { Change in \% } \\
\text { within range } \\
\text { from } 2012\end{array}$ & $\begin{array}{c}95 \% \\
\text { LCL } \\
\text { change }\end{array}$ & $\begin{array}{l}95 \% \\
\text { UCL } \\
\text { change }\end{array}$ \\
\hline \multicolumn{10}{|l|}{ N Ireland } \\
\hline Antrim & 120 & 62.5 & 53.5 & 70.7 & 34.2 & 3.3 & -4.7 & -16.6 & 7.2 \\
\hline Belfast & 196 & 52.6 & 45.6 & 59.5 & 35.7 & 11.7 & -5.1 & -14.8 & 4.7 \\
\hline Newry & 84 & 59.5 & 48.8 & 69.5 & 34.5 & 6.0 & 13.6 & -1.3 & 28.6 \\
\hline Ulster & 102 & 46.1 & 36.7 & 55.8 & 49.0 & 4.9 & -1.4 & -15.2 & 12.3 \\
\hline West NI & 107 & 71.0 & 61.8 & 78.8 & 21.5 & 7.5 & 4.4 & -7.5 & 16.2 \\
\hline \multicolumn{10}{|l|}{ Wales } \\
\hline Bangor & 83 & 67.5 & 56.7 & 76.7 & 30.1 & 2.4 & 10.7 & -4.1 & 25.4 \\
\hline Cardff & 451 & 65.9 & 61.4 & 70.1 & 18.6 & 15.5 & -5.5 & -11.6 & 0.7 \\
\hline Clwyd & 72 & 54.2 & 42.6 & 65.3 & 27.8 & 18.1 & -7.7 & -23.5 & 8.2 \\
\hline Swanse & 230 & 61.7 & 55.3 & 67.8 & 24.4 & 13.9 & -1.1 & -10.0 & 7.8 \\
\hline Wrexm & 93 & 53.8 & 43.6 & 63.6 & 45.2 & 1.1 & -5.8 & -20.4 & 8.8 \\
\hline England & 17,324 & 56.7 & 56.0 & 57.5 & 26.1 & 17.1 & -0.4 & -1.4 & 0.7 \\
\hline $\mathrm{N}$ Ireland & 609 & 57.6 & 53.7 & 61.5 & 35.0 & 7.4 & -0.5 & -6.0 & 5.0 \\
\hline Wales & 929 & 62.9 & 59.7 & 65.9 & 24.4 & 12.7 & -3.1 & -7.5 & 1.3 \\
\hline E, W \& NI & 18,862 & 57.1 & 56.4 & 57.8 & 26.3 & 16.6 & -0.5 & -1.6 & 0.5 \\
\hline
\end{tabular}

Blank cells: no data available for 2012

Table 8.13. Summary statistics for PTH in peritoneal dialysis patients in 2013

\begin{tabular}{|c|c|c|c|c|c|c|c|}
\hline Centre & $\begin{array}{c}\% \\
\text { completeness }\end{array}$ & $\begin{array}{c}\text { Patients with data } \\
\qquad N\end{array}$ & Mean & SD & Median & $\begin{array}{l}\text { Lower } \\
\text { quartile }\end{array}$ & $\begin{array}{l}\text { Upper } \\
\text { quartile }\end{array}$ \\
\hline \multicolumn{8}{|l|}{ England } \\
\hline B Heart & 88.6 & 31 & 51.8 & 42.9 & 38 & 26 & 79 \\
\hline B QEH & 97.7 & 126 & 39.0 & 40.2 & 25 & 14 & 42 \\
\hline Basldn & 100.0 & 30 & 39.8 & 29.3 & 30 & 18 & 57 \\
\hline Bradfd & 88.5 & 23 & 39.2 & 49.9 & 25 & 4 & 47 \\
\hline Brightn & 97.0 & 64 & 32.2 & 25.2 & 23 & 12 & 49 \\
\hline Bristol & 96.5 & 55 & 37.1 & 28.1 & 32 & 17 & 46 \\
\hline Camb & 100.0 & 19 & & & & & \\
\hline Carlis & 87.0 & 20 & 40.6 & 25.6 & 28 & 26 & 54 \\
\hline Carsh & 48.6 & 51 & & & & & \\
\hline \multirow{2}{*}{\multicolumn{8}{|c|}{ Colchr* }} \\
\hline & & & & & & & \\
\hline Covnt & 91.7 & 66 & 22.9 & 19.9 & 18 & 11 & 28 \\
\hline Derby & 97.4 & 76 & 29.5 & 19.6 & 26 & 16 & 35 \\
\hline Donc & 96.7 & 29 & 54.4 & 33.7 & 40 & 33 & 63 \\
\hline Dorset & 89.7 & 35 & 27.7 & 18.5 & 24 & 13 & 40 \\
\hline Dudley & 87.2 & 41 & 34.7 & 40.8 & 18 & 10 & 41 \\
\hline Exeter & 100.0 & 63 & 24.8 & 19.3 & 18 & 12 & 35 \\
\hline Glouc & 83.9 & 26 & 35.7 & 22.8 & 26 & 18 & 47 \\
\hline Hull & 55.6 & 40 & 25.5 & 23.0 & 22 & 8 & 34 \\
\hline Ipswi & 91.7 & 22 & 56.9 & 52.1 & 32 & 16 & 87 \\
\hline Kent & 96.5 & 55 & 41.2 & 32.4 & 29 & 19 & 57 \\
\hline L Barts & 95.5 & 170 & 36.0 & 35.3 & 27 & 12 & 48 \\
\hline
\end{tabular}


Table 8.13. Continued

\begin{tabular}{|c|c|c|c|c|c|c|c|}
\hline Centre & $\begin{array}{c}\% \\
\text { completeness }\end{array}$ & $\begin{array}{c}\text { Patients with data } \\
\qquad N\end{array}$ & Mean & SD & Median & $\begin{array}{l}\text { Lower } \\
\text { quartile }\end{array}$ & $\begin{array}{l}\text { Upper } \\
\text { quartile }\end{array}$ \\
\hline L Guys & 57.1 & 16 & & & & & \\
\hline L Rfree & 84.3 & 91 & 46.1 & 47.3 & 35 & 17 & 58 \\
\hline L St.G & 91.1 & 41 & 31.7 & 27.3 & 22 & 16 & 41 \\
\hline Leic & 89.6 & 121 & 42.2 & 35.7 & 33 & 16 & 59 \\
\hline Liv Ain & 92.3 & 24 & 17.0 & 12.7 & 13 & 10 & 20 \\
\hline Liv Roy & 94.1 & 48 & 30.7 & 23.1 & 24 & 13 & 40 \\
\hline M RI & 94.2 & 65 & 37.6 & 22.1 & 37 & 21 & 50 \\
\hline Middlbr & 90.9 & 10 & & & & & \\
\hline Oxford & 95.2 & 79 & 44.1 & 37.6 & 35 & 18 & 57 \\
\hline Plymth & 75.9 & 22 & 23.6 & 24.1 & 18 & 10 & 33 \\
\hline Ports & 87.0 & 67 & 43.6 & 34.8 & 33 & 15 & 68 \\
\hline Prestn & 100.0 & 52 & 42.2 & 28.5 & 38 & 24 & 54 \\
\hline Redng & 95.3 & 61 & 31.1 & 18.7 & 27 & 17 & 41 \\
\hline Salford & 94.7 & 71 & 39.9 & 39.7 & 25 & 13 & 47 \\
\hline Sheff & 86.9 & 53 & 34.0 & 24.0 & 29 & 18 & 46 \\
\hline Shrew & 100.0 & 26 & 42.6 & 42.0 & 24 & 19 & 57 \\
\hline Stevng & 86.5 & 32 & 37.1 & 21.9 & 38 & 19 & 52 \\
\hline Sthend & 60.0 & 9 & & & & & \\
\hline Stoke & 87.7 & 71 & 52.8 & 46.0 & 36 & 23 & 67 \\
\hline Antrim & 100.0 & 15 & & & & & \\
\hline Belfast & 100.0 & 26 & 27.7 & 20.3 & 23 & 10 & 37 \\
\hline Newry & 100.0 & 17 & & & & & \\
\hline Ulster & 100.0 & 4 & & & & & \\
\hline West NI & 100.0 & 14 & & & & & \\
\hline \multicolumn{8}{|l|}{ Wales } \\
\hline Bangor & 91.7 & 11 & & & & & \\
\hline Cardff & 92.4 & 61 & 49.6 & 30.9 & 45 & 28 & 71 \\
\hline Clwyd & 92.9 & 13 & & & & & \\
\hline Swanse & 88.7 & 47 & 38.3 & 28.1 & 33 & 17 & 46 \\
\hline Wrexm & 100.0 & 19 & & & & & \\
\hline England & 90.0 & 2,485 & 39.1 & 35.9 & 29 & 16 & 51 \\
\hline N Ireland & 100.0 & 76 & 25.9 & 19.6 & 22 & 12 & 34 \\
\hline Wales & 92.1 & 151 & 42.2 & 27.9 & 38 & 19 & 57 \\
\hline E, W \& NI & 90.3 & 2,712 & 38.9 & 35.2 & 29 & 16 & 51 \\
\hline
\end{tabular}

Blank cells: centres excluded from analyses due to small numbers or poor data completeness

* No PD patients 
Table 8.14. Percentage of peritoneal dialysis patients within, below and above the range for PTH (16-72 pmol/L) in 2013

\begin{tabular}{|c|c|c|c|c|c|c|c|c|c|}
\hline Centre & $N$ & $\begin{array}{c}\% \text { PTH } \\
16-72 \mathrm{pmol} / \mathrm{L}\end{array}$ & $\begin{array}{l}\text { Lower } \\
95 \% \text { CI }\end{array}$ & $\begin{array}{c}\text { Upper } \\
95 \% \text { CI }\end{array}$ & $\begin{array}{c}\% \mathrm{PTH} \\
<16 \mathrm{pmol} / \mathrm{L}\end{array}$ & $\begin{array}{c}\% \text { phos } \\
>72 \mathrm{pmol} / \mathrm{L}\end{array}$ & $\begin{array}{c}\text { Change in } \% \\
\text { within range } \\
\text { from } 2012\end{array}$ & $\begin{array}{c}95 \% \\
\text { LCL } \\
\text { change }\end{array}$ & $\begin{array}{c}95 \% \\
\text { UCL } \\
\text { change }\end{array}$ \\
\hline \multicolumn{10}{|l|}{ England } \\
\hline B Heart & 31 & 61.3 & 43.5 & 76.5 & 12.9 & 25.8 & -13.7 & -36.5 & 9.1 \\
\hline B QEH & 126 & 61.9 & 53.1 & 70.0 & 26.2 & 11.9 & -4.5 & -16.0 & 7.0 \\
\hline Basldn & 30 & 66.7 & 48.4 & 81.0 & 20.0 & 13.3 & -14.8 & -37.2 & 7.5 \\
\hline Bradfd & 23 & 47.8 & 28.8 & 67.5 & 39.1 & 13.0 & -6.7 & -35.9 & 22.4 \\
\hline Brightn & 64 & 59.4 & 47.0 & 70.7 & 34.4 & 6.3 & -4.6 & -21.6 & 12.5 \\
\hline Bristol & 55 & 67.3 & 53.9 & 78.3 & 20.0 & 12.7 & 6.9 & -11.2 & 25.0 \\
\hline Carlis & 20 & 80.0 & 57.2 & 92.3 & 5.0 & 15.0 & 20.0 & -7.7 & 47.7 \\
\hline Covnt & 66 & 59.1 & 46.9 & 70.2 & 37.9 & 3.0 & -2.0 & -18.1 & 14.2 \\
\hline Derby & 76 & 72.4 & 61.3 & 81.2 & 22.4 & 5.3 & -1.1 & -14.9 & 12.7 \\
\hline Donc & 29 & 72.4 & 53.8 & 85.6 & 6.9 & 20.7 & 7.2 & -18.2 & 32.6 \\
\hline Dorset & 35 & 71.4 & 54.6 & 83.9 & 28.6 & 0.0 & 4.8 & -18.5 & 28.0 \\
\hline Dudley & 41 & 48.8 & 34.1 & 63.7 & 41.5 & 9.8 & -3.4 & -24.4 & 17.6 \\
\hline Exeter & 63 & 57.1 & 44.7 & 68.7 & 39.7 & 3.2 & 7.1 & -9.9 & 24.2 \\
\hline Glouc & 26 & 76.9 & 57.2 & 89.3 & 15.4 & 7.7 & 19.2 & -5.7 & 44.2 \\
\hline Hull & 40 & 57.5 & 42.0 & 71.7 & 37.5 & 5.0 & 3.2 & -16.0 & 22.5 \\
\hline Ipswi & 22 & 54.6 & 34.1 & 73.5 & 18.2 & 27.3 & -4.1 & -31.5 & 23.4 \\
\hline Kent & 55 & 63.6 & 50.3 & 75.2 & 18.2 & 18.2 & -0.4 & -18.8 & 18.0 \\
\hline L Barts & 170 & 56.5 & 48.9 & 63.7 & 32.4 & 11.2 & -7.0 & -17.8 & 3.7 \\
\hline L Kings & 76 & 56.6 & 45.3 & 67.2 & 19.7 & 23.7 & -1.3 & -17.0 & 14.4 \\
\hline L Rfree & 91 & 61.5 & 51.2 & 70.9 & 22.0 & 16.5 & -6.1 & -20.8 & 8.7 \\
\hline L St.G & 41 & 65.9 & 50.3 & 78.6 & 24.4 & 9.8 & -5.6 & -25.5 & 14.4 \\
\hline L West & 52 & 61.5 & 47.8 & 73.7 & 19.2 & 19.2 & -8.0 & -26.8 & 10.7 \\
\hline Leeds & 62 & 64.5 & 51.9 & 75.4 & 19.4 & 16.1 & -1.7 & -17.6 & 14.2 \\
\hline Leic & 121 & 61.2 & 52.2 & 69.4 & 23.1 & 15.7 & 1.3 & -10.6 & 13.3 \\
\hline Liv Ain & 24 & 29.2 & 14.6 & 49.8 & 70.8 & 0.0 & & & \\
\hline Liv Roy & 48 & 62.5 & 48.2 & 74.9 & 29.2 & 8.3 & -1.0 & -19.9 & 18.0 \\
\hline M RI & 65 & 73.9 & 61.9 & 83.1 & 15.4 & 10.8 & 0.9 & -13.8 & 15.6 \\
\hline Newc & 30 & 53.3 & 35.8 & 70.1 & 36.7 & 10.0 & -21.7 & -45.0 & 1.6 \\
\hline Norwch & 35 & 71.4 & 54.6 & 83.9 & 14.3 & 14.3 & 20.3 & -0.9 & 41.4 \\
\hline Nottm & 66 & 66.7 & 54.5 & 76.9 & 15.2 & 18.2 & 3.3 & -12.7 & 19.3 \\
\hline Oxford & 79 & 59.5 & 48.4 & 69.7 & 21.5 & 19.0 & -5.6 & -21.6 & 10.4 \\
\hline Plymth & 22 & 50.0 & 30.2 & 69.8 & 45.5 & 4.6 & 10.7 & -16.9 & 38.3 \\
\hline Ports & 67 & 49.3 & 37.6 & 61.0 & 28.4 & 22.4 & -18.3 & -34.2 & -2.4 \\
\hline Prestn & 52 & 69.2 & 55.5 & 80.2 & 17.3 & 13.5 & & & \\
\hline Redng & 61 & 75.4 & 63.1 & 84.6 & 19.7 & 4.9 & 7.2 & -8.6 & 22.9 \\
\hline Salford & 71 & 54.9 & 43.3 & 66.1 & 26.8 & 18.3 & -6.5 & -22.1 & 9.1 \\
\hline Sheff & 53 & 67.9 & 54.3 & 79.0 & 22.6 & 9.4 & -5.2 & -22.6 & 12.3 \\
\hline Shrew & 26 & 69.2 & 49.5 & 83.8 & 15.4 & 15.4 & 1.5 & -22.7 & 25.7 \\
\hline Stevng & 32 & 75.0 & 57.4 & 87.0 & 18.8 & 6.3 & 23.0 & -1.7 & 47.7 \\
\hline Stoke & 71 & 70.4 & 58.9 & 79.9 & 9.9 & 19.7 & 2.3 & -13.0 & 17.6 \\
\hline Wolve & 77 & 68.8 & 57.7 & 78.2 & 19.5 & 11.7 & -3.2 & -17.7 & 11.3 \\
\hline York & 25 & 64.0 & 44.0 & 80.1 & 32.0 & 4.0 & 0.0 & -26.6 & 26.6 \\
\hline \multicolumn{10}{|l|}{ N Ireland } \\
\hline Belfast & 26 & 57.7 & 38.5 & 74.8 & 38.5 & 3.9 & -7.5 & -34.7 & 19.7 \\
\hline \multicolumn{10}{|l|}{ Wales } \\
\hline Cardff & 61 & 60.7 & 48.0 & 72.0 & 16.4 & 23.0 & -5.1 & -21.6 & 11.5 \\
\hline Swanse & 47 & 68.1 & 53.6 & 79.8 & 21.3 & 10.6 & -3.9 & -22.1 & 14.3 \\
\hline England & 2,485 & 62.9 & 60.9 & 64.7 & 24.0 & 13.2 & -1.7 & -4.3 & 1.0 \\
\hline N Ireland & 76 & 60.5 & 49.2 & 70.8 & 36.8 & 2.6 & -4.2 & -20.0 & 11.6 \\
\hline Wales & 151 & 68.9 & 61.1 & 75.7 & 16.6 & 14.6 & 0.6 & -9.7 & 10.8 \\
\hline E, W \& NI & 2,712 & 63.1 & 61.3 & 64.9 & 23.9 & 12.9 & -1.6 & -4.2 & 0.9 \\
\hline
\end{tabular}

Blank cells: no data available for 2012 


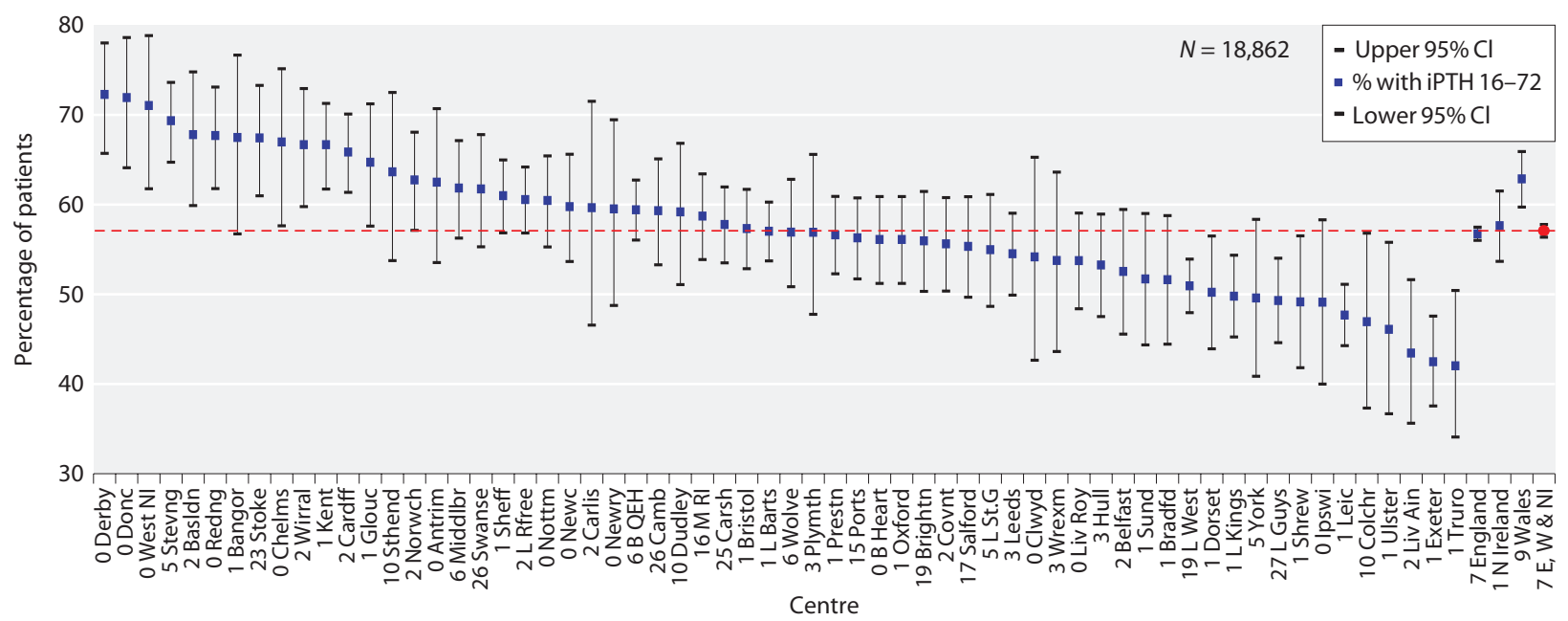

Fig. 8.11. Percentage of haemodialysis patients with $\mathrm{PTH}$ within range (16-72 pmol/L) by centre in 2013

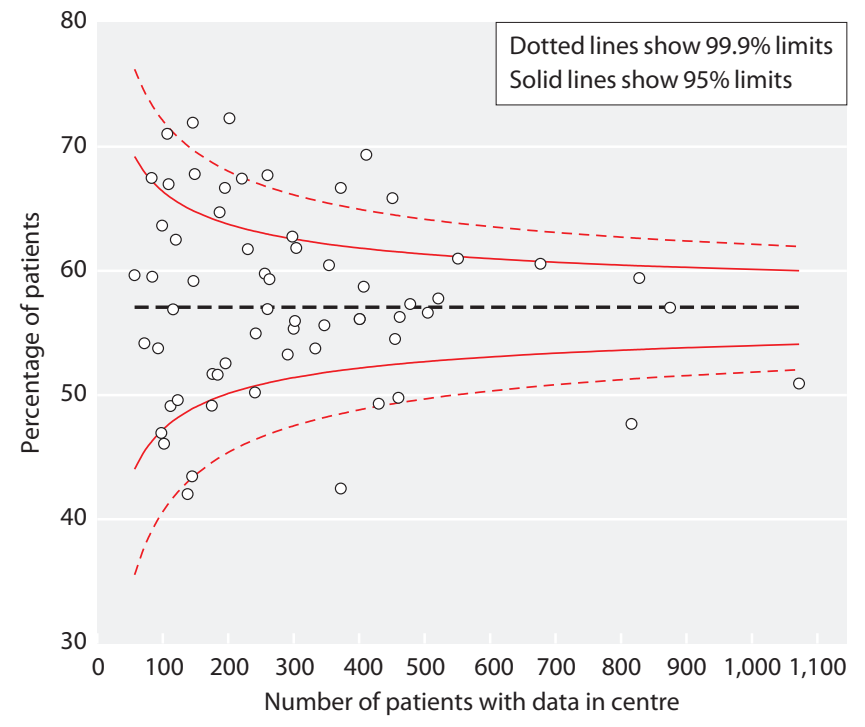

Fig. 8.12. Funnel plot of percentage of haemodialysis patients with PTH within range (16-72 $\mathrm{pmol} / \mathrm{L})$ by centre in 2013

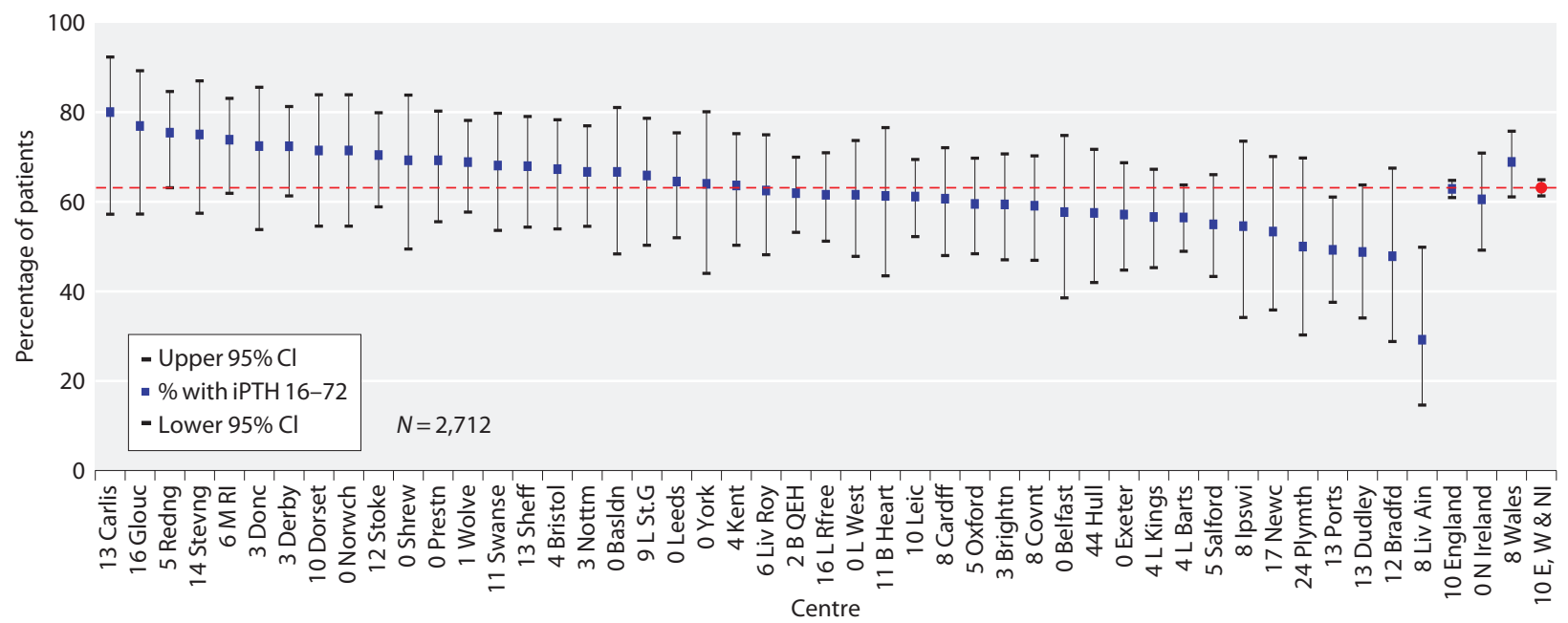

Fig. 8.13. Percentage of peritoneal dialysis patients with $\mathrm{PTH}$ within range $(16-72 \mathrm{pmol} / \mathrm{L})$ by centre in 2013 


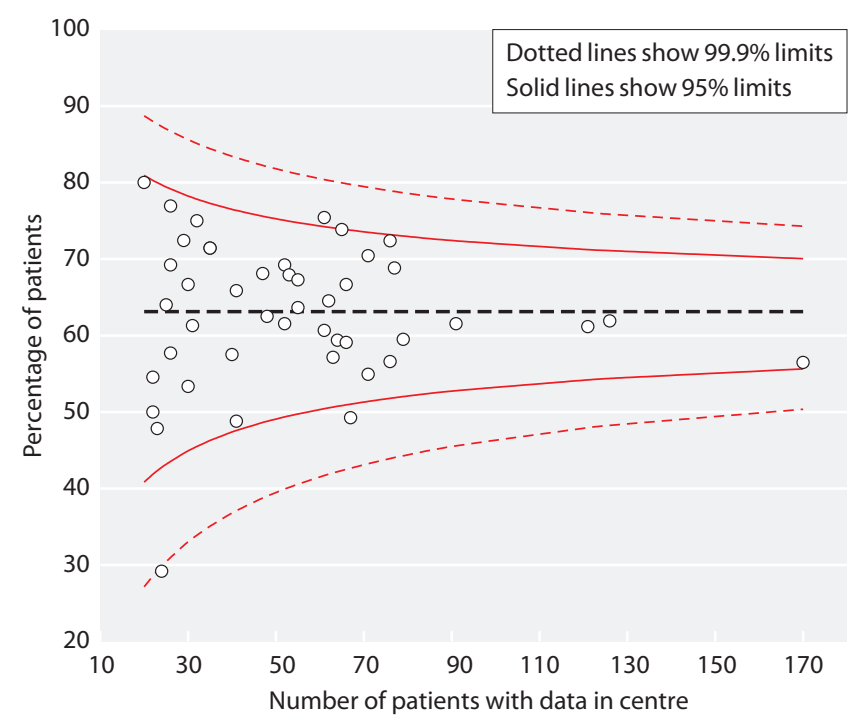

Fig. 8.14. Funnel plot of percentage of peritoneal dialysis patients with PTH within range $(16-72 \mathrm{pmol} / \mathrm{L})$ by centre in 2013

Changes in PTH control between 2003 and 2013 stratified by dialysis modality are shown in figure 8.15 .

Simultaneous control of corrected calcium, phosphate and PTH in preventing severe hyperparathyroidism

Data points to perform the bone mineral disease (BMD) combination analyses were available from $61 \mathrm{HD}$ and $45 \mathrm{PD}$ centres, covering 18,428 $\mathrm{HD}$ and 2,433 PD patients, from England, Wales and Northern Ireland.

Tables 8.15 and 8.16 identify each centre and detail the numbers of patients who had received $\mathrm{HD}$ and $\mathrm{PD}$ and the results of the BMD combination analyses.

Figures 8.16 and 8.17 demonstrate the caterpillar plots of all centres and the percentage achievement of simultaneous control of all three BMD parameters for $\mathrm{HD}$ and $\mathrm{PD}$ patients respectively.

Control of none of the parameters of BMD was found in $1.9 \%$ of $\mathrm{HD}$ patients and $1.6 \%$ of $\mathrm{PD}$ patients across England, Wales and Northern Ireland cumulatively. Control of one parameter was reported in $13.0 \%$ of $\mathrm{HD}$ and $12.5 \%$ of PD patients; of two parameters in $35.9 \%$ of $\mathrm{HD}$ and $35.8 \%$ of PD patients; and of all three parameters in $49.3 \%$ of $\mathrm{HD}$ and $50.1 \%$ of PD patients (tables 8.15, 8.16).

Figures 8.18 and 8.19 are funnel plots of all centres who contributed data to these analyses based on the size of the centre and the percentage of patients achieving the control of all three BMD parameters. In HD patients, there was a negative trend observed between centre size and the simultaneous control of all three BMD parameters as identified in this analysis. No such trend was observed in PD patients, perhaps because PD centres are all of a small size.

\section{Bicarbonate}

In 2013 the following Renal Association clinical practice guidelines regarding bicarbonate management were applicable:

Haemodialysis Guideline 6.3: Pre-dialysis serum bicarbonate concentrations

'We suggest that pre-dialysis serum bicarbonate concentrations, measured with minimum delay after venepuncture, should be between 18 and $24 \mathrm{mmol} / \mathrm{l}$ [7].

Peritoneal Dialysis Guideline 6.2 - PD: Metabolic factors

'We recommend that plasma bicarbonate should be maintained within the normal range' [8].

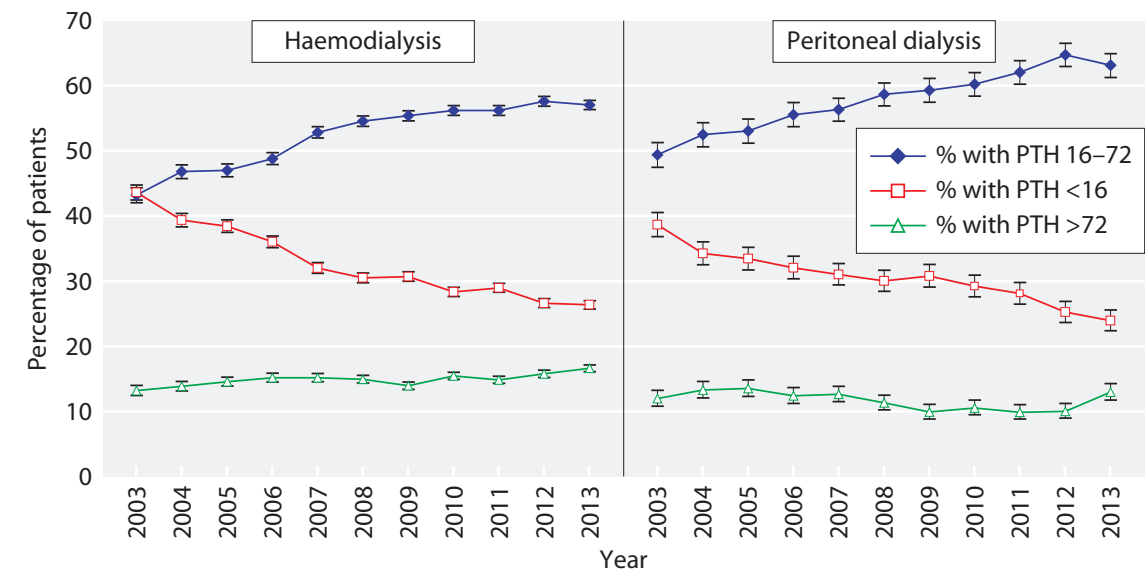

Fig. 8.15. Longitudinal change in percentage of patients with PTH within range $(16-72 \mathrm{pmol} / \mathrm{L})$ by dialysis modality 2003-2013 
Table 8.15. Percentage of haemodialysis patients within the ranges specified for the simultaneous combinations of control of bone and mineral disorder parameters in preventing severe hyper parathyroidism in 2013

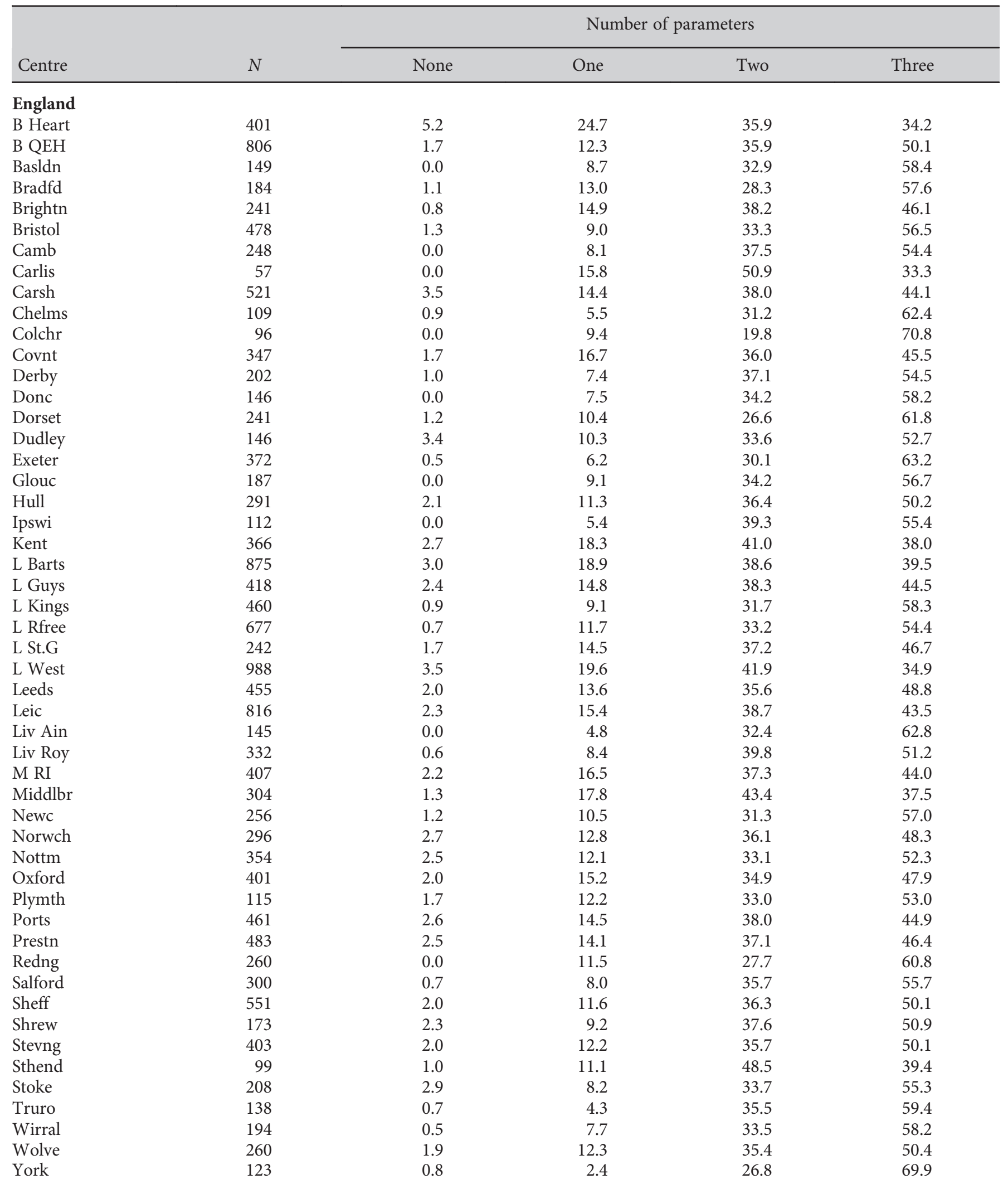


Table 8.15. Continued

\begin{tabular}{|c|c|c|c|c|c|}
\hline \multirow[b]{2}{*}{ Centre } & \multirow[b]{2}{*}{$N$} & \multicolumn{4}{|c|}{ Number of parameters } \\
\hline & & None & One & Two & Three \\
\hline \multicolumn{6}{|l|}{$\mathrm{N}$ Ireland } \\
\hline Antrim & 120 & 0.0 & 5.0 & 33.3 & 61.7 \\
\hline Belfast & 194 & 2.6 & 11.9 & 30.9 & 54.6 \\
\hline Newry & 82 & 1.2 & 7.3 & 35.4 & 56.1 \\
\hline Ulster & 102 & 2.0 & 4.9 & 34.3 & 58.8 \\
\hline West NI & 107 & 0.9 & 7.5 & 37.4 & 54.2 \\
\hline \multicolumn{6}{|l|}{ Wales } \\
\hline Bangor & 83 & 1.2 & 3.6 & 32.5 & 62.7 \\
\hline Cardff & 451 & 3.3 & 18.2 & 33.0 & 45.5 \\
\hline Clwyd & 72 & 1.4 & 12.5 & 38.9 & 47.2 \\
\hline Swanse & 230 & 0.9 & 13.9 & 36.1 & 49.1 \\
\hline Wrexm & 93 & 0.0 & 6.5 & 34.4 & 59.1 \\
\hline England & 16,894 & 1.9 & 13.1 & 36.1 & 49.0 \\
\hline N Ireland & 605 & 1.5 & 7.9 & 33.7 & 56.9 \\
\hline Wales & 929 & 2.0 & 14.2 & 34.3 & 49.4 \\
\hline E, W \& NI & 18,428 & 1.9 & 13.0 & 35.9 & 49.3 \\
\hline
\end{tabular}

Table 8.16. Percentage of peritoneal dialysis patients within the ranges specified for the simultaneous combinations of control of bone and mineral disorder parameters in preventing severe hyperparathyroidism in 2013

\begin{tabular}{|c|c|c|c|c|c|}
\hline \multirow[b]{2}{*}{ Centre } & \multirow[b]{2}{*}{$N$} & \multicolumn{4}{|c|}{ Number of parameters } \\
\hline & & None & One & Two & Three \\
\hline \multicolumn{6}{|l|}{ England } \\
\hline B Heart & 31 & 3.2 & 22.6 & 32.3 & 41.9 \\
\hline B QEH & 126 & 2.4 & 12.7 & 34.9 & 50.0 \\
\hline Basldn & 30 & 3.3 & 13.3 & 20.0 & 63.3 \\
\hline Bradfd & 22 & 0.0 & 18.2 & 45.5 & 36.4 \\
\hline Brightn & 64 & 0.0 & 6.3 & 45.3 & 48.4 \\
\hline Bristol & 55 & 0.0 & 10.9 & 52.7 & 36.4 \\
\hline Covnt & 64 & 0.0 & 3.1 & 26.6 & 70.3 \\
\hline Derby & 76 & 0.0 & 11.8 & 38.2 & 50.0 \\
\hline Donc & 29 & 3.4 & 6.9 & 41.4 & 48.3 \\
\hline Dorset & 30 & 0.0 & 3.3 & 23.3 & 73.3 \\
\hline Dudley & 41 & 0.0 & 12.2 & 46.3 & 41.5 \\
\hline Exeter & 63 & 0.0 & 7.9 & 25.4 & 66.7 \\
\hline Glouc & 26 & 0.0 & 7.7 & 38.5 & 53.8 \\
\hline Hull & 40 & 2.5 & 2.5 & 40.0 & 55.0 \\
\hline Ipswi & 22 & 4.5 & 27.3 & 18.2 & 50.0 \\
\hline Kent & 54 & 0.0 & 22.2 & 44.4 & 33.3 \\
\hline L Barts & 169 & 1.8 & 12.4 & 39.1 & 46.7 \\
\hline L Kings & 76 & 0.0 & 10.5 & 39.5 & 50.0 \\
\hline L Rfree & 91 & 0.0 & 12.1 & 38.5 & 49.5 \\
\hline L St.G & 40 & 2.5 & 5.0 & 42.5 & 50.0 \\
\hline L West & 52 & 3.8 & 17.3 & 53.8 & 25.0 \\
\hline Leeds & 62 & 3.2 & 21.0 & 35.5 & 40.3 \\
\hline Leic & 121 & 0.8 & 9.9 & 41.3 & 47.9 \\
\hline Liv Ain & 24 & 0.0 & 8.3 & 29.2 & 62.5 \\
\hline Liv Roy & 48 & 0.0 & 2.1 & 41.7 & 56.3 \\
\hline M RI & 64 & 1.6 & 12.5 & 32.8 & 53.1 \\
\hline Newc & 30 & 0.0 & 13.3 & 46.7 & 40.0 \\
\hline
\end{tabular}


Table 8.16. Continued

\begin{tabular}{|c|c|c|c|c|c|}
\hline \multirow[b]{2}{*}{ Centre } & \multirow[b]{2}{*}{$N$} & \multicolumn{4}{|c|}{ Number of parameters } \\
\hline & & None & One & Two & Three \\
\hline Nottm & 66 & 0.0 & 16.7 & 28.8 & 54.5 \\
\hline Oxford & 79 & 2.5 & 21.5 & 31.6 & 44.3 \\
\hline Plymth & 22 & 4.5 & 9.1 & 27.3 & 59.1 \\
\hline Redng & 61 & 1.6 & 6.6 & 23.0 & 68.9 \\
\hline Salford & 71 & 2.8 & 16.9 & 31.0 & 49.3 \\
\hline Sheff & 53 & 0.0 & 13.2 & 34.0 & 52.8 \\
\hline Shrew & 26 & 7.7 & 7.7 & 30.8 & 53.8 \\
\hline Stevng & 32 & 0.0 & 12.5 & 18.8 & 68.8 \\
\hline Stoke & 63 & 6.3 & 17.5 & 33.3 & 42.9 \\
\hline \multicolumn{6}{|l|}{ Wales } \\
\hline Cardff & 61 & 4.9 & 18.0 & 45.9 & 31.1 \\
\hline Swanse & 47 & 0.0 & 6.4 & 44.7 & 48.9 \\
\hline England & 2,299 & 1.6 & 12.5 & 35.3 & 50.6 \\
\hline N Ireland & 26 & 0.0 & 7.7 & 42.3 & 50.0 \\
\hline Wales & 108 & 2.8 & 13.0 & 45.4 & 38.9 \\
\hline E, W \& NI & 2,433 & 1.6 & 12.5 & 35.8 & 50.1 \\
\hline
\end{tabular}

Bicarbonate data were $93 \%$ complete for HD patients and $92 \%$ complete for PD patients (tables 8.17, 8.19). The proportion of HD patients with a serum bicarbonate within the audit measure range was 59\% in 2013 (95\% CI 59-60\%) (table 8.18); the mean bicarbonate in $\mathrm{HD}$ patients was $23 \mathrm{mmol} / \mathrm{L}$ (table 8.17).
The proportion with a serum bicarbonate within the audit standard in PD patients was 79\% (CI 77-80\%) (table 8.20). The mean bicarbonate level in PD patients was $25 \mathrm{mmol} / \mathrm{L}$ (table 8.19).

As in previous years, between centre variation was observed in attainment of the audit standard for both

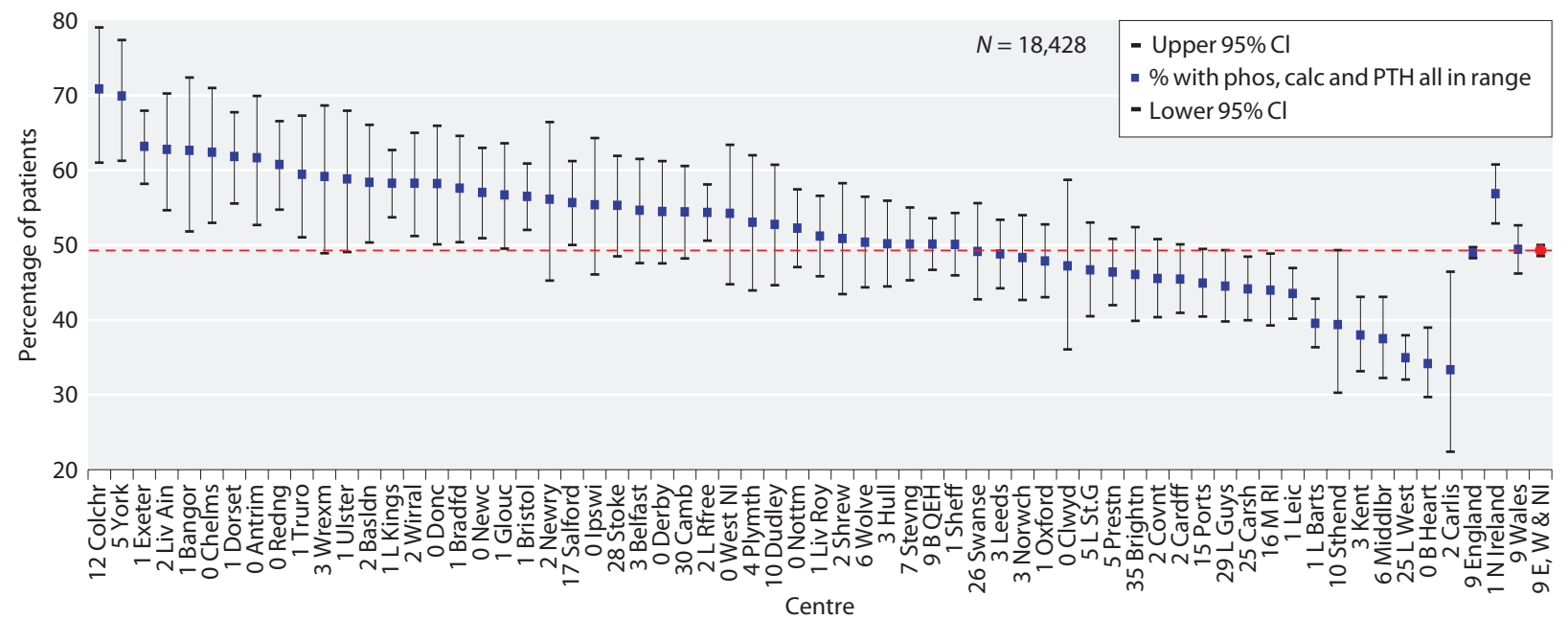

Fig. 8.16. Percentage of HD patients achieving simultaneous control of all three BMD parameters in preventing severe hyperparathyroidism by centre in 2013 


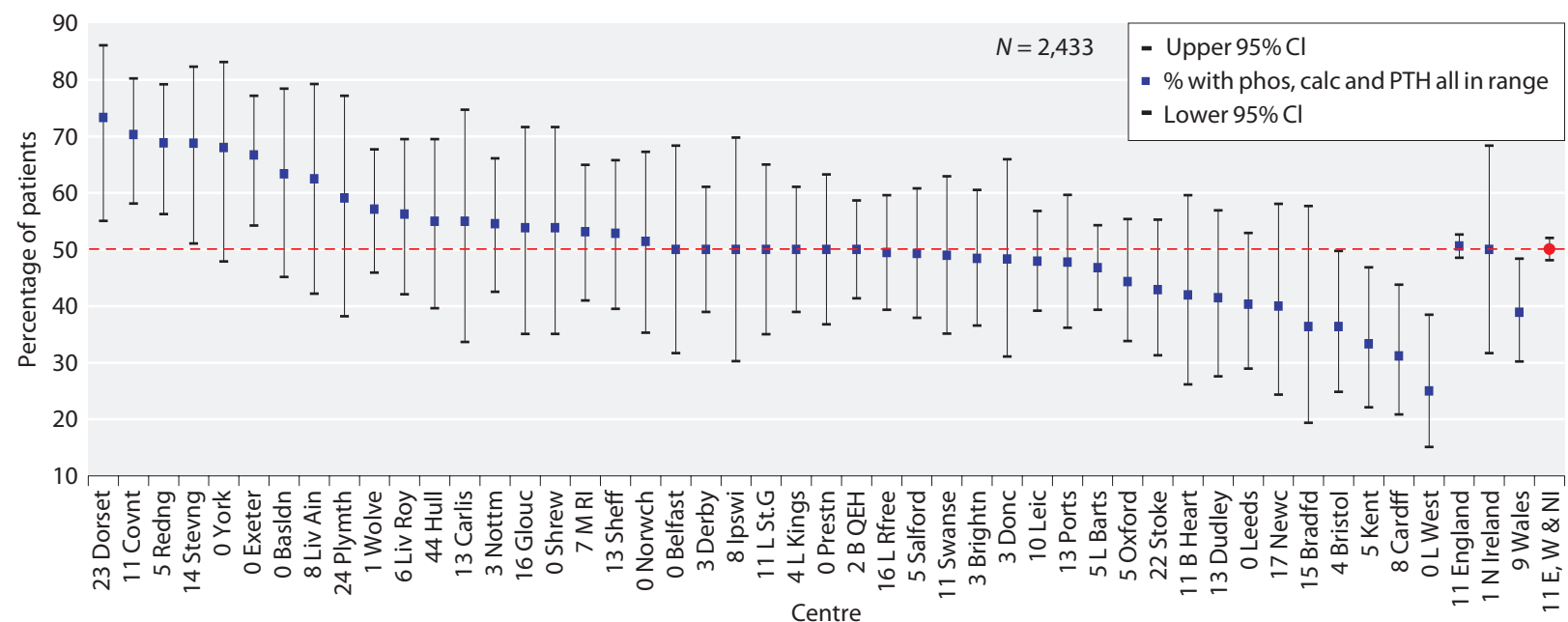

Fig. 8.17. Percentage of PD patients achieving simultaneous control of all three BMD parameters in preventing severe hyperparathyroidism by centre in 2013
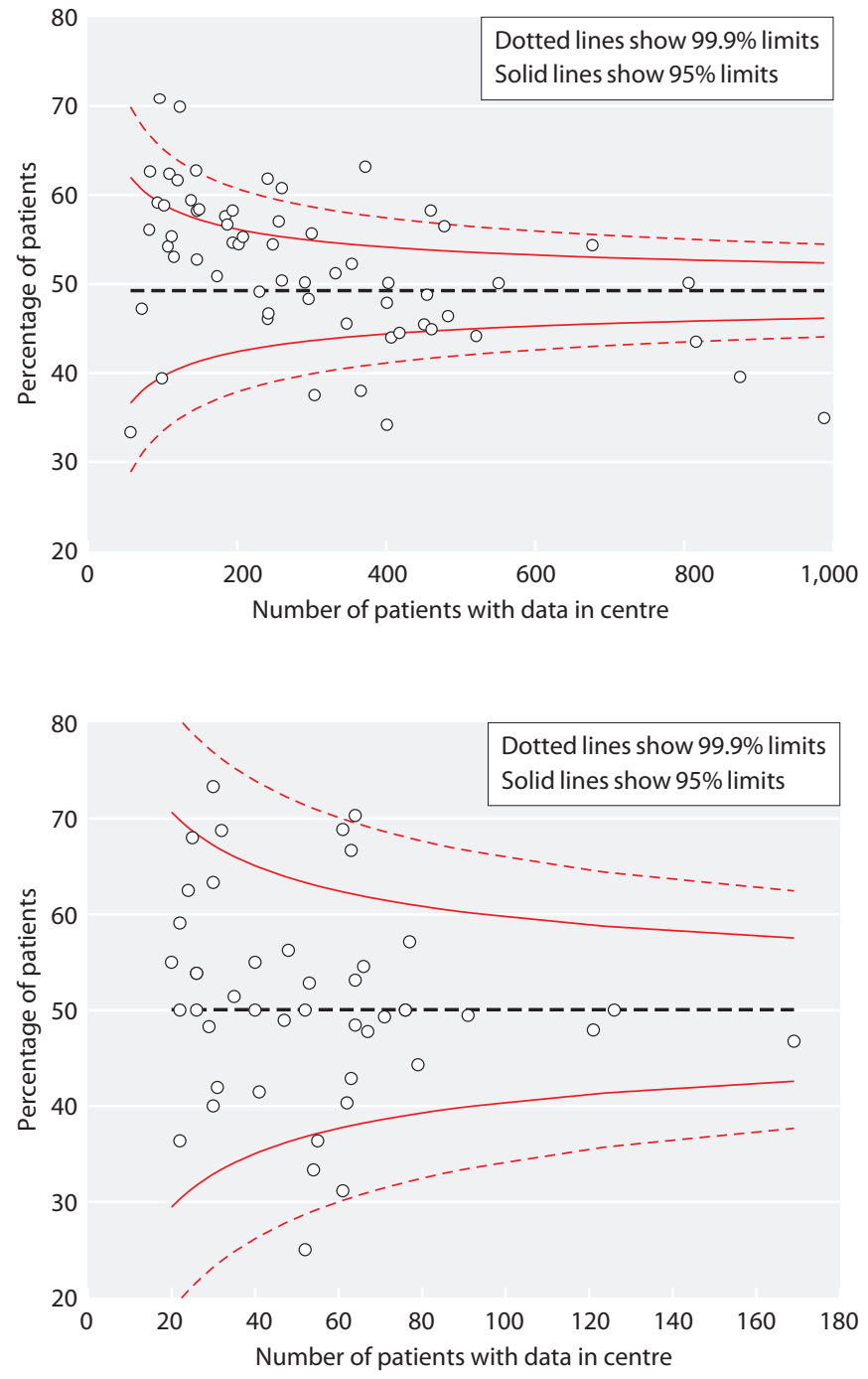

Fig. 8.18. Funnel plot for percentage of $\mathrm{HD}$ patients achieving simultaneous control of all three BMD parameters in preventing severe hyperparathyroidism by centre in 2013

Fig. 8.19. Funnel plot for percentage of PD patients achieving simultaneous control of all three BMD parameters in preventing severe hyperparathyroidism by centre in 2013 
Table 8.17. Summary statistics for serum bicarbonate in haemodialysis patients by centre in 2013

\begin{tabular}{|c|c|c|c|c|c|c|c|}
\hline Centre & $\begin{array}{c}\% \\
\text { completeness }\end{array}$ & $\begin{array}{c}\text { Patients with data } \\
\qquad N\end{array}$ & Mean & SD & Median & $\begin{array}{l}\text { Lower } \\
\text { quartile }\end{array}$ & $\begin{array}{l}\text { Upper } \\
\text { quartile }\end{array}$ \\
\hline \multicolumn{8}{|l|}{ England } \\
\hline B QEH & 98.6 & 873 & 23.9 & 2.5 & 24 & 22 & 26 \\
\hline Basldn & 99.3 & 151 & 22.2 & 2.7 & 22 & 20 & 24 \\
\hline Bradfd & 100.0 & 186 & 24.0 & 2.7 & 24 & 22 & 26 \\
\hline Camb & 94.4 & 336 & 24.1 & 2.7 & 24 & 22 & 26 \\
\hline Carlis & 100.0 & 58 & 21.4 & 2.6 & 21 & 19 & 24 \\
\hline Carsh & 93.6 & 653 & 24.9 & 3.8 & 25 & 22 & 28 \\
\hline Chelms & 100.0 & 109 & 22.4 & 2.1 & 22 & 21 & 24 \\
\hline Colchr & 92.7 & 101 & 25.1 & 1.4 & 25 & 24 & 26 \\
\hline Dudley & 94.5 & 154 & 23.1 & 3.1 & 23 & 21 & 25 \\
\hline Exeter & 100.0 & 376 & 22.7 & 2.7 & 23 & 21 & 24 \\
\hline Glouc & 100.0 & 188 & 23.5 & 2.5 & 24 & 22 & 25 \\
\hline Hull & 100.0 & 299 & 23.4 & 2.5 & 24 & 22 & 25 \\
\hline Ipswi & 98.2 & 110 & 22.7 & 2.9 & 23 & 21 & 24 \\
\hline Kent & 99.5 & 374 & 21.1 & 2.6 & 21 & 20 & 23 \\
\hline L Barts & 99.7 & 880 & 20.5 & 2.5 & 21 & 19 & 22 \\
\hline L Guys & 66.7 & 394 & 22.9 & 2.9 & 23 & 21 & 25 \\
\hline L Kings & 99.8 & 465 & 25.8 & 2.1 & 26 & 25 & 27 \\
\hline L Rfree & 98.4 & 677 & 23.0 & 2.8 & 23 & 21 & 25 \\
\hline L St.G & 98.8 & 252 & 27.8 & 3.1 & 28 & 26 & 30 \\
\hline Newc & 100.0 & 257 & 26.3 & 3.0 & 27 & 25 & 28 \\
\hline Norwch & 99.7 & 304 & 24.4 & 3.1 & 25 & 22 & 26 \\
\hline Nottm & 94.4 & 334 & 25.4 & 3.0 & 25 & 24 & 27 \\
\hline Oxford & 99.8 & 404 & 24.3 & 3.3 & 25 & 22 & 26 \\
\hline Plymth & 98.3 & 118 & 24.8 & 1.9 & 25 & 23 & 26 \\
\hline Ports & 98.0 & 534 & 23.7 & 3.3 & 24 & 22 & 26 \\
\hline Prestn & 99.4 & 505 & 23.8 & 2.9 & 24 & 22 & 26 \\
\hline Redng & 100.0 & 260 & 24.8 & 3.0 & 25 & 23 & 27 \\
\hline Salford & 9.9 & 36 & & & & & \\
\hline Sheff & 99.8 & 555 & 23.7 & 3.0 & 24 & 22 & 26 \\
\hline Shrew & 100.0 & 176 & 23.4 & 3.2 & 24 & 22 & 26 \\
\hline Stevng & 97.5 & 420 & 23.1 & 3.0 & 23 & 21 & 25 \\
\hline Sthend & 100.0 & 110 & 24.9 & 3.9 & 25 & 23 & 27 \\
\hline Stoke & 76.0 & 219 & 24.5 & 2.8 & 25 & 22 & 26 \\
\hline Sund & 100.0 & 177 & 27.9 & 2.8 & 28 & 26 & 30 \\
\hline Truro & 100.0 & 139 & 23.0 & 2.4 & 23 & 22 & 24 \\
\hline Wirral & 93.4 & 185 & 23.9 & 2.7 & 24 & 22 & 26 \\
\hline Wolve & 99.6 & 276 & 19.0 & 2.3 & 19 & 18 & 20 \\
\hline York & 100.0 & 129 & 24.1 & 2.7 & 24 & 22 & 26 \\
\hline
\end{tabular}


Table 8.17. Continued

\begin{tabular}{|c|c|c|c|c|c|c|c|}
\hline Centre & $\begin{array}{c}\% \\
\text { completeness }\end{array}$ & $\begin{array}{l}\text { Patients with data } \\
\qquad N\end{array}$ & Mean & SD & Median & $\begin{array}{l}\text { Lower } \\
\text { quartile }\end{array}$ & $\begin{array}{l}\text { Upper } \\
\text { quartile }\end{array}$ \\
\hline \multicolumn{8}{|l|}{ N Ireland } \\
\hline Antrim & 98.3 & 118 & 23.8 & 2.8 & 24 & 22 & 26 \\
\hline Belfast & 99.5 & 198 & 22.6 & 2.8 & 23 & 21 & 24 \\
\hline Newry & 100.0 & 84 & 22.3 & 2.2 & 22 & 21 & 24 \\
\hline Ulster & 100.0 & 103 & 24.3 & 2.4 & 24 & 23 & 26 \\
\hline West NI & 100.0 & 107 & 23.2 & 2.6 & 23 & 22 & 25 \\
\hline \multicolumn{8}{|l|}{ Wales } \\
\hline Bangor & 100.0 & 84 & 26.1 & 3.2 & 26 & 24 & 28 \\
\hline Cardff & 99.1 & 456 & 23.3 & 3.3 & 24 & 21 & 26 \\
\hline Clwyd & 100.0 & 72 & 22.3 & 2.5 & 22 & 21 & 24 \\
\hline Swanse & 99.7 & 310 & 23.0 & 3.4 & 23 & 20 & 25 \\
\hline Wrexm & 100.0 & 96 & 22.6 & 2.3 & 23 & 21 & 24 \\
\hline England & 92.1 & 17,189 & 23.4 & 3.4 & 23 & 21 & 26 \\
\hline N Ireland & 99.5 & 610 & 23.2 & 2.7 & 23 & 22 & 25 \\
\hline Wales & 99.5 & 1,018 & 23.3 & 3.3 & 23 & 21 & 26 \\
\hline E, W \& NI & 92.7 & 18,817 & 23.4 & 3.4 & 23 & 21 & 26 \\
\hline
\end{tabular}

Blank cells: centres excluded from analyses due to poor data completeness

Table 8.18. Percentage of haemodialysis patients within, below and above the range for bicarbonate (18-24 mmol/L) by centre in 2013

\begin{tabular}{|c|c|c|c|c|c|c|c|c|c|}
\hline Centre & $N$ & $\begin{array}{c}\% \text { bicarb } \\
18-24 \mathrm{mmol} / \mathrm{L}\end{array}$ & $\begin{array}{l}\text { Lower } \\
95 \% \text { CI }\end{array}$ & $\begin{array}{l}\text { Upper } \\
95 \% \text { CI }\end{array}$ & $\begin{array}{c}\% \text { bicarb } \\
<18 \mathrm{mmol} / \mathrm{L}\end{array}$ & $\begin{array}{c}\% \text { bicarb } \\
>24 \mathrm{mmol} / \mathrm{L}\end{array}$ & $\begin{array}{l}\text { Change in } \% \\
\text { within range } \\
\text { from } 2012\end{array}$ & $\begin{array}{c}\text { 95\% } \\
\text { LCL } \\
\text { change }\end{array}$ & $\begin{array}{l}95 \% \\
\text { UCL } \\
\text { change }\end{array}$ \\
\hline B Heart & 275 & 81.5 & 76.4 & 85.6 & 8.7 & 9.8 & 3.3 & -2.9 & 9.5 \\
\hline B QEH & 873 & 58.2 & 54.9 & 61.4 & 0.8 & 41.0 & -3.9 & -8.5 & 0.8 \\
\hline Basldn & 151 & 76.2 & 68.7 & 82.3 & 4.0 & 19.9 & 6.7 & -3.4 & 16.9 \\
\hline Brightn & 354 & 65.5 & 60.4 & 70.3 & 4.2 & 30.2 & 1.4 & -5.9 & 8.7 \\
\hline Bristol & 485 & 63.9 & 59.5 & 68.1 & 2.5 & 33.6 & -11.6 & -17.4 & -5.8 \\
\hline Camb & 336 & 58.0 & 52.7 & 63.2 & 0.6 & 41.4 & -7.1 & -14.6 & 0.4 \\
\hline Carlis & 58 & 77.6 & 65.1 & 86.5 & 6.9 & 15.5 & 14.4 & -2.1 & 30.9 \\
\hline Carsh & 653 & 42.4 & 38.7 & 46.3 & 2.3 & 55.3 & -10.6 & -16.0 & -5.2 \\
\hline Chelms & 109 & 83.5 & 75.3 & 89.3 & 0.9 & 15.6 & -3.3 & -12.5 & 5.9 \\
\hline Dorset & 241 & 77.6 & 71.9 & 82.4 & 2.1 & 20.3 & 3.5 & -4.1 & 11.1 \\
\hline Dudley & 154 & 69.5 & 61.8 & 76.2 & 2.6 & 27.9 & 10.3 & -0.4 & 20.9 \\
\hline Exeter & 376 & 77.7 & 73.2 & 81.6 & 3.5 & 18.9 & -4.1 & -9.9 & 1.8 \\
\hline Glouc & 188 & 64.9 & 57.8 & 71.4 & 1.6 & 33.5 & 6.6 & -3.1 & 16.4 \\
\hline Hull & 299 & 64.9 & 59.3 & 70.1 & 2.0 & 33.1 & -21.9 & -28.5 & -15.2 \\
\hline Ipswi & 110 & 73.6 & 64.6 & 81.0 & 1.8 & 24.6 & 3.5 & -8.0 & 15.0 \\
\hline Kent & 374 & 82.4 & 78.2 & 85.9 & 8.3 & 9.4 & 0.5 & -5.0 & 6.1 \\
\hline
\end{tabular}


Table 8.18. Continued

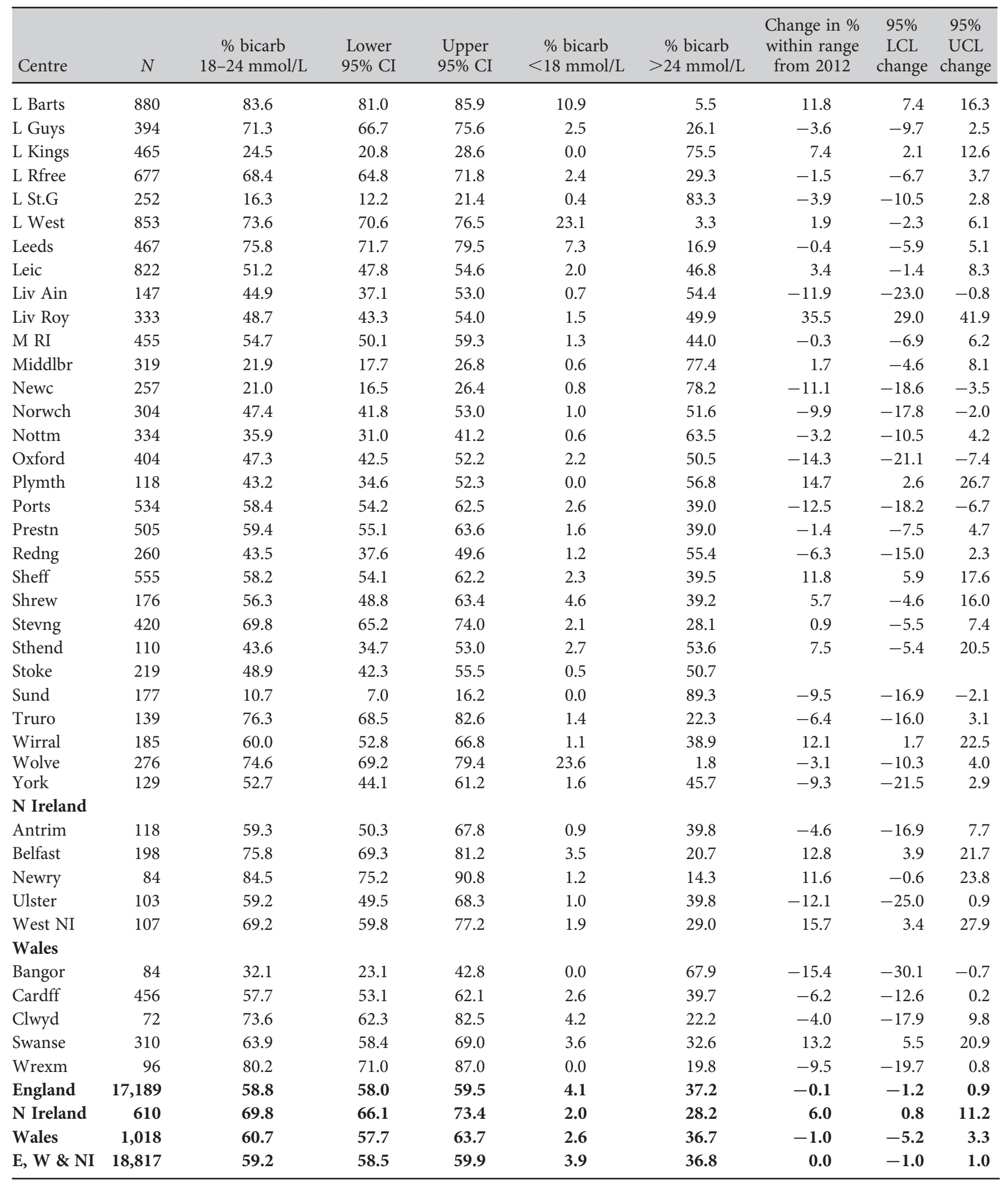

Blank cells: no data available for 2012 
Table 8.19. Summary statistics for serum bicarbonate in peritoneal dialysis patients by centre in 2013

\begin{tabular}{|c|c|c|c|c|c|c|c|}
\hline Centre & $\begin{array}{c}\% \\
\text { completeness }\end{array}$ & $\begin{array}{c}\text { Patients with data } \\
\qquad N\end{array}$ & Mean & $\mathrm{SD}$ & Median & $\begin{array}{l}\text { Lower } \\
\text { quartile }\end{array}$ & $\begin{array}{l}\text { Upper } \\
\text { quartile }\end{array}$ \\
\hline \multicolumn{8}{|l|}{ England } \\
\hline B QEH & 94.6 & 122 & 23.7 & 3.1 & 24 & 22 & 26 \\
\hline Basldn & 80.0 & 24 & 25.5 & 2.6 & 26 & 24 & 28 \\
\hline Bradfd & 96.2 & 25 & 26.5 & 2.2 & 27 & 25 & 28 \\
\hline Bristol & 98.3 & 56 & 22.9 & 2.6 & 23 & 21 & 25 \\
\hline Camb & 89.5 & 17 & & & & & \\
\hline Carlis & 100.0 & 23 & 22.7 & 2.4 & 23 & 22 & 24 \\
\hline Carsh & 77.1 & 81 & 23.1 & 3.0 & 23 & 21 & 25 \\
\hline Chelms & 95.0 & 19 & & & & & \\
\hline \multicolumn{8}{|l|}{ Colchr* } \\
\hline Dudley & 97.9 & 46 & 24.6 & 4.0 & 24 & 22 & 27 \\
\hline Exeter & 100.0 & 63 & 24.5 & 2.6 & 25 & 23 & 26 \\
\hline Glouc & 100.0 & 31 & 24.5 & 3.0 & 25 & 22 & 27 \\
\hline Hull & 100.0 & 72 & 25.3 & 3.2 & 26 & 23 & 28 \\
\hline Ipswi & 100.0 & 24 & 27.1 & 2.9 & 28 & 25 & 29 \\
\hline Kent & 100.0 & 57 & 22.9 & 2.5 & 23 & 21 & 25 \\
\hline L Barts & 98.9 & 176 & 22.3 & 2.8 & 22 & 21 & 24 \\
\hline L Guys & 85.7 & 24 & 23.0 & 3.5 & 23 & 20 & 27 \\
\hline L Kings & 98.7 & 78 & 25.6 & 2.6 & 26 & 24 & 27 \\
\hline L Rfree & 74.1 & 80 & 24.6 & 3.3 & 25 & 23 & 27 \\
\hline L St.G & 100.0 & 45 & 28.4 & 2.9 & 29 & 27 & 30 \\
\hline Newc & 88.9 & 32 & 25.7 & 3.2 & 26 & 24 & 28 \\
\hline Norwch & 97.1 & 34 & 24.3 & 2.3 & 24 & 23 & 26 \\
\hline Nottm & 50.0 & 34 & 27.8 & 3.3 & 28 & 27 & 30 \\
\hline Oxford & 80.7 & 67 & 25.2 & 3.1 & 25 & 23 & 27 \\
\hline Plymth & 93.1 & 27 & 23.7 & 3.4 & 25 & 21 & 26 \\
\hline Ports & 96.1 & 74 & 26.4 & 3.6 & 27 & 24 & 29 \\
\hline Prestn & 100.0 & 52 & 26.2 & 3.4 & 27 & 24 & 29 \\
\hline Redng & 100.0 & 64 & 26.8 & 3.3 & 26 & 24 & 29 \\
\hline Salford & 9.3 & 7 & & & & & \\
\hline Sheff & 100.0 & 61 & 24.7 & 3.3 & 25 & 23 & 27 \\
\hline Shrew & 100.0 & 26 & 25.4 & 3.2 & 25 & 23 & 28 \\
\hline Stevng & 89.2 & 33 & 26.4 & 3.1 & 27 & 25 & 28 \\
\hline Sthend & 100.0 & 15 & & & & & \\
\hline Stoke & 98.8 & 80 & 25.5 & 3.0 & 25 & 24 & 27 \\
\hline Sund & 100.0 & 8 & & & & & \\
\hline Truro & 94.4 & 17 & & & & & \\
\hline Wirral & 74.1 & 20 & 25.8 & 3.4 & 26 & 24 & 28 \\
\hline Wolve & 98.7 & 77 & 21.3 & 2.3 & 21 & 20 & 23 \\
\hline York & 100.0 & 25 & 26.7 & 2.8 & 26 & 24 & 29 \\
\hline
\end{tabular}


Table 8.19. Continued

\begin{tabular}{|c|c|c|c|c|c|c|c|}
\hline Centre & $\begin{array}{c}\% \\
\text { completeness }\end{array}$ & $\begin{array}{c}\text { Patients with data } \\
\qquad N\end{array}$ & Mean & SD & Median & $\begin{array}{l}\text { Lower } \\
\text { quartile }\end{array}$ & $\begin{array}{l}\text { Upper } \\
\text { quartile }\end{array}$ \\
\hline \multicolumn{8}{|l|}{ N Ireland } \\
\hline Antrim & 73.3 & 11 & & & & & \\
\hline Belfast & 100.0 & 26 & 23.8 & 3.2 & 24 & 21 & 26 \\
\hline Newry & 100.0 & 17 & & & & & \\
\hline Ulster & 100.0 & 4 & & & & & \\
\hline West NI & 92.9 & 13 & & & & & \\
\hline \multicolumn{8}{|l|}{ Wales } \\
\hline Bangor & 100.0 & 12 & & & & & \\
\hline Cardff & 100.0 & 66 & 25.4 & 3.1 & 26 & 23 & 27 \\
\hline Clwyd & 100.0 & 14 & & & & & \\
\hline Swanse & 100.0 & 53 & 24.7 & 2.6 & 25 & 23 & 27 \\
\hline Wrexm & 100.0 & 19 & & & & & \\
\hline England & 91.1 & 2,516 & 24.8 & 3.4 & 25 & 23 & 27 \\
\hline $\mathrm{N}$ Ireland & 93.4 & 71 & 24.4 & 3.3 & 24 & 22 & 27 \\
\hline Wales & 100.0 & 164 & 25.0 & 3.0 & 25 & 23 & 27 \\
\hline E, W \& NI & 91.6 & 2,751 & 24.8 & 3.4 & 25 & 23 & 27 \\
\hline
\end{tabular}

Blank cells: low patient numbers or poor data completeness

*No PD patients

Table 8.20. Percentage of peritoneal dialysis patients within, below and above the range for bicarbonate (22-30 $\mathrm{mmol} / \mathrm{L}) \mathrm{by} \mathrm{centre} \mathrm{in} 2013$

\begin{tabular}{|c|c|c|c|c|c|c|c|c|c|}
\hline Centre & $N$ & $\begin{array}{c}\% \text { bicarb } \\
22-30 \mathrm{mmol} / \mathrm{L}\end{array}$ & $\begin{array}{l}\text { Lower } \\
95 \% \text { CI }\end{array}$ & $\begin{array}{l}\text { Upper } \\
95 \% \text { CI }\end{array}$ & $\begin{array}{c}\% \text { bicarb } \\
<22 \mathrm{mmol} / \mathrm{L}\end{array}$ & $\begin{array}{c}\% \text { bicarb } \\
>30 \mathrm{mmol} / \mathrm{L}\end{array}$ & $\begin{array}{c}\text { Change in } \% \\
\text { within range } \\
\text { from } 2012\end{array}$ & $\begin{array}{c}95 \% \\
\text { LCL } \\
\text { change }\end{array}$ & $\begin{array}{c}95 \% \\
\text { UCL } \\
\text { change }\end{array}$ \\
\hline \multicolumn{10}{|l|}{ England } \\
\hline B Heart & 35 & 57.1 & 40.6 & 72.3 & 42.9 & 0.0 & 15.7 & -6.6 & 38.0 \\
\hline B QEH & 122 & 75.4 & 67.0 & 82.2 & 23.8 & 0.8 & 3.1 & -7.6 & 13.9 \\
\hline Basldn & 24 & 91.7 & 72.1 & 97.9 & 8.3 & 0.0 & 17.6 & -2.3 & 37.5 \\
\hline Bradfd & 25 & 96.0 & 76.5 & 99.4 & 0.0 & 4.0 & -4.0 & -11.7 & 3.7 \\
\hline Brightn & 66 & 75.8 & 64.0 & 84.6 & 24.2 & 0.0 & -4.2 & -19.0 & 10.5 \\
\hline Bristol & 56 & 73.2 & 60.2 & 83.2 & 26.8 & 0.0 & 10.7 & -6.5 & 27.9 \\
\hline Carlis & 23 & 78.3 & 57.2 & 90.7 & 21.7 & 0.0 & 21.1 & -5.9 & 48.2 \\
\hline Carsh & 81 & 66.7 & 55.8 & 76.0 & 33.3 & 0.0 & -14.0 & -27.2 & -0.8 \\
\hline Covnt & 62 & 91.9 & 82.1 & 96.6 & 6.5 & 1.6 & 5.5 & -4.9 & 15.8 \\
\hline Derby & 76 & 89.5 & 80.3 & 94.7 & 10.5 & 0.0 & 7.3 & -3.4 & 18.0 \\
\hline Donc & 30 & 83.3 & 65.7 & 92.9 & 6.7 & 10.0 & 5.1 & -16.4 & 26.6 \\
\hline Dorset & 35 & 68.6 & 51.7 & 81.7 & 31.4 & 0.0 & -3.4 & -26.8 & 19.9 \\
\hline Dudley & 46 & 67.4 & 52.7 & 79.3 & 23.9 & 8.7 & -17.2 & -34.0 & -0.5 \\
\hline Exeter & 63 & 85.7 & 74.8 & 92.4 & 14.3 & 0.0 & 30.6 & 16.1 & 45.2 \\
\hline Glouc & 31 & 87.1 & 70.3 & 95.1 & 9.7 & 3.2 & 0.4 & -16.5 & 17.4 \\
\hline Hull & 72 & 83.3 & 72.9 & 90.3 & 12.5 & 4.2 & -7.3 & -18.2 & 3.5 \\
\hline Ipswi & 24 & 91.7 & 72.1 & 97.9 & 4.2 & 4.2 & 18.3 & -1.0 & 37.6 \\
\hline Kent & 57 & 66.7 & 53.6 & 77.6 & 33.3 & 0.0 & -13.0 & -29.2 & 3.3 \\
\hline L Barts & 176 & 61.4 & 54.0 & 68.3 & 38.6 & 0.0 & -17.8 & -27.3 & -8.3 \\
\hline L Guys & 24 & 62.5 & 42.2 & 79.2 & 37.5 & 0.0 & -14.4 & -39.7 & 10.8 \\
\hline L Kings & 78 & 91.0 & 82.4 & 95.7 & 5.1 & 3.9 & 9.5 & -1.3 & 20.2 \\
\hline L Rfree & 80 & 80.0 & 69.8 & 87.4 & 17.5 & 2.5 & -3.1 & -15.0 & 8.8 \\
\hline L St.G & 45 & 77.8 & 63.4 & 87.6 & 0.0 & 22.2 & -11.4 & -26.5 & 3.8 \\
\hline L West & 52 & 73.1 & 59.5 & 83.4 & 26.9 & 0.0 & 19.9 & 1.2 & 38.6 \\
\hline Leeds & 62 & 90.3 & 80.1 & 95.6 & 3.2 & 6.5 & 8.5 & -2.8 & 19.8 \\
\hline Leic & 126 & 77.8 & 69.7 & 84.2 & 10.3 & 11.9 & -1.2 & -11.2 & 8.7 \\
\hline Liv Ain & 26 & 96.2 & 77.2 & 99.5 & 0.0 & 3.9 & & & \\
\hline Liv Roy & 51 & 94.1 & 83.3 & 98.1 & 5.9 & 0.0 & 11.1 & -0.9 & 23.1 \\
\hline
\end{tabular}


Table 8.20. Continued

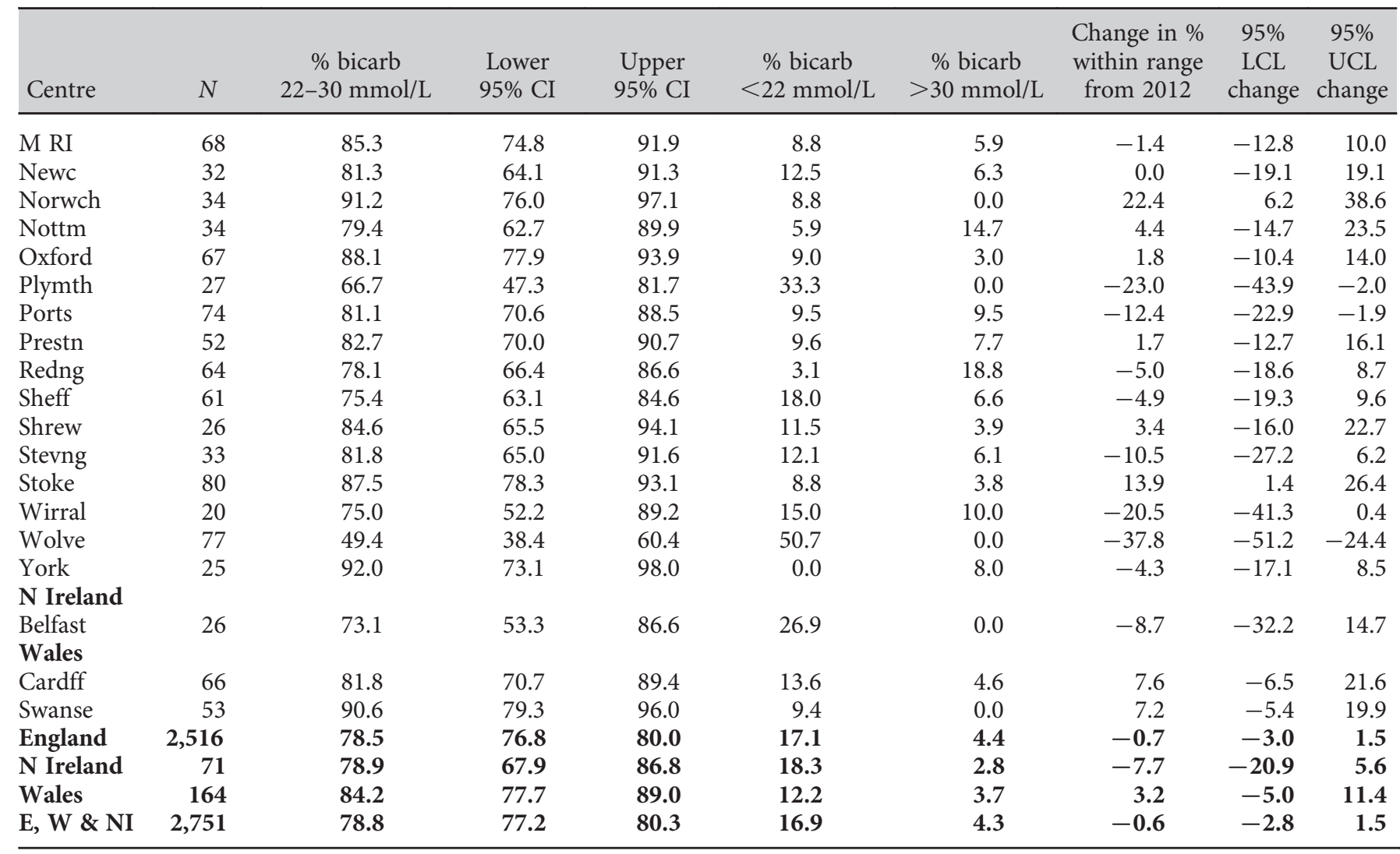

Blank cells: no data available for 2012

$\mathrm{HD}$ and $\mathrm{PD}$ groups (tables 8.18, 8.20, figures 8.208.23).

There was a notable deterioration in the achievement of bicarbonate within range compared with 2012 at a number of centres (tables 8.18, 8.20). For these HD centres there was a uniform shift to higher bicarbonate concentrations (Doncaster, Hull, Oxford, Bangor) whereas for PD centres there was a downward shift in

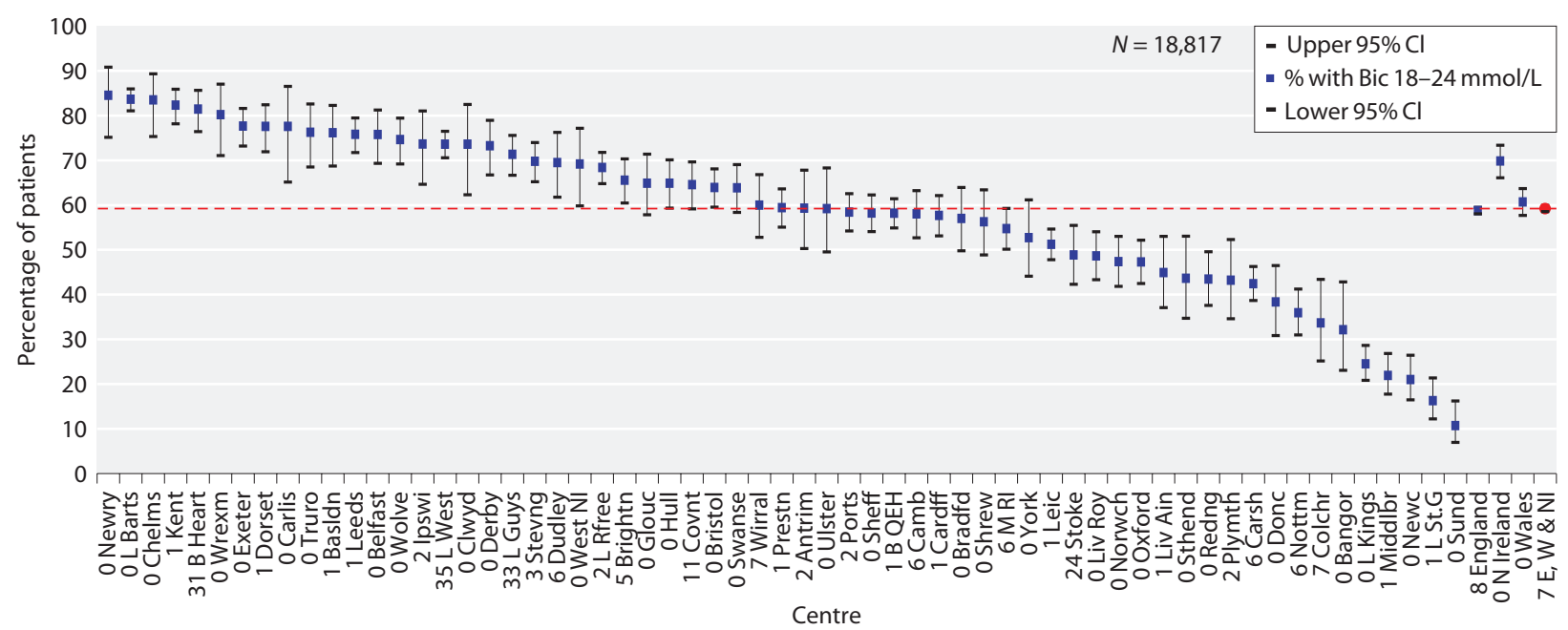

Fig. 8.20. Percentage of haemodialysis patients with serum bicarbonate within range (18-24 mmol/L) by centre in 2013 


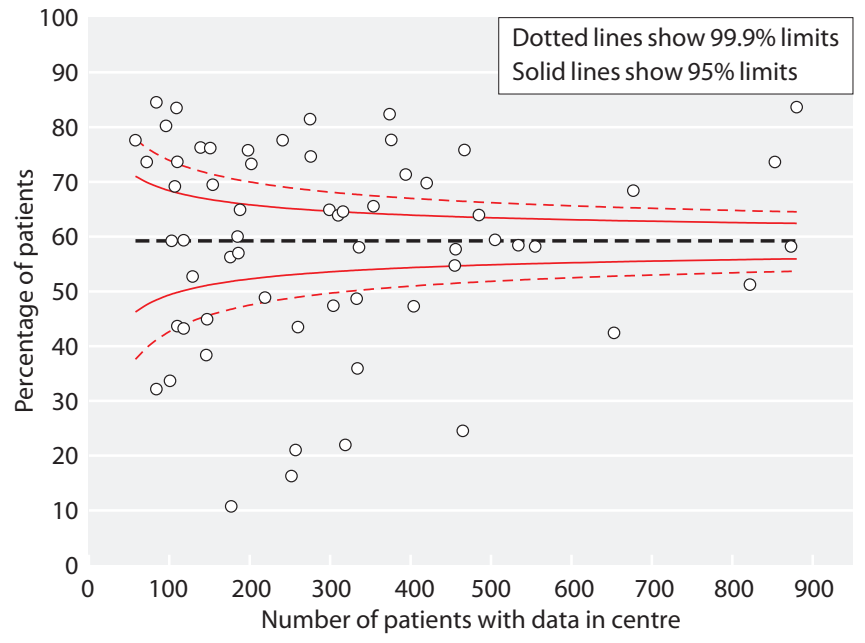

Fig. 8.21. Funnel plot for percentage of haemodialysis patients within the range for bicarbonate $(18-24 \mathrm{mmol} / \mathrm{L})$ by centre in 2013

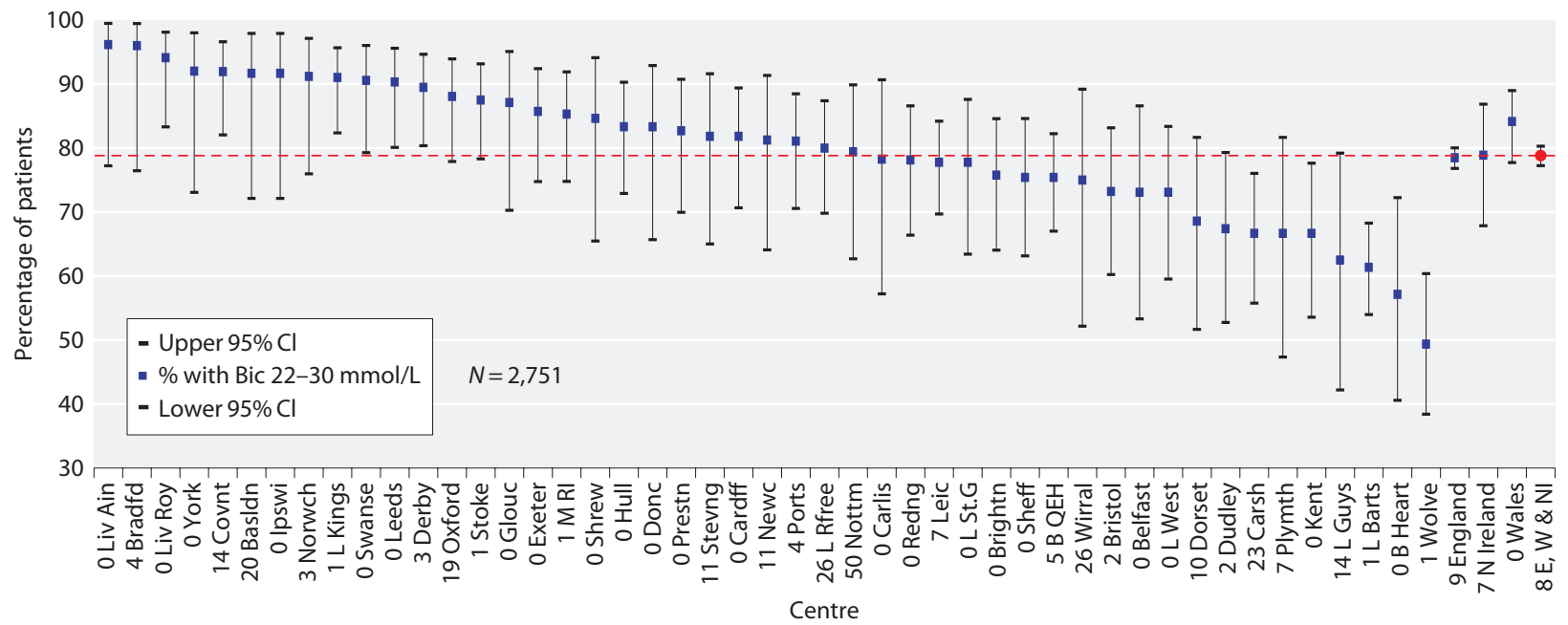

Fig. 8.22. Percentage of peritoneal dialysis patients with serum bicarbonate within range $(22-30 \mathrm{mmol} / \mathrm{L})$ by centre in 2013

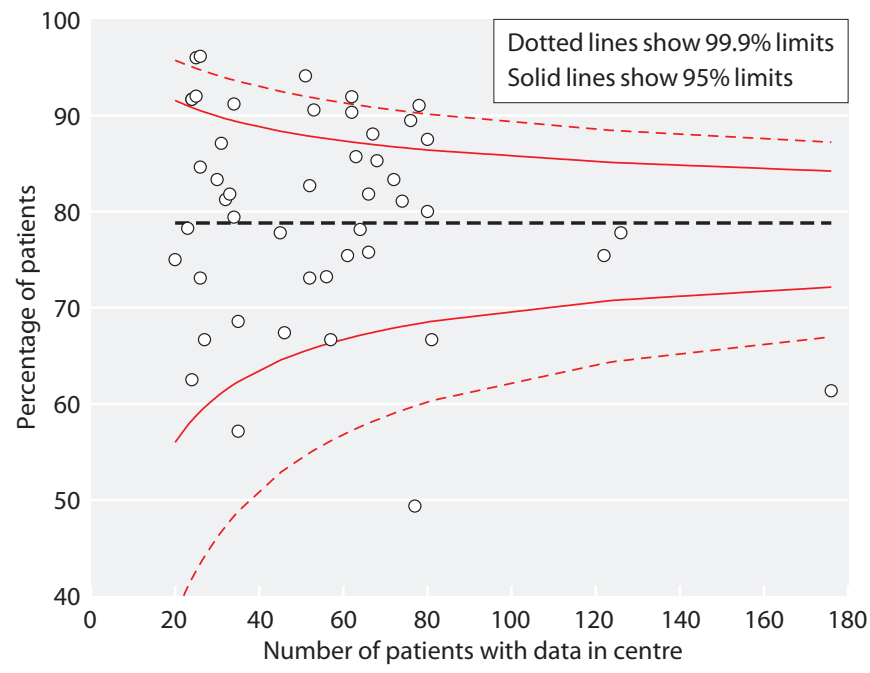

Management of biochemical variables
Fig. 8.23. Funnel plot for percentage of peritoneal dialysis patients within the range for bicarbonate $(22-30 \mathrm{mmol} / \mathrm{L})$ by centre in 2013 


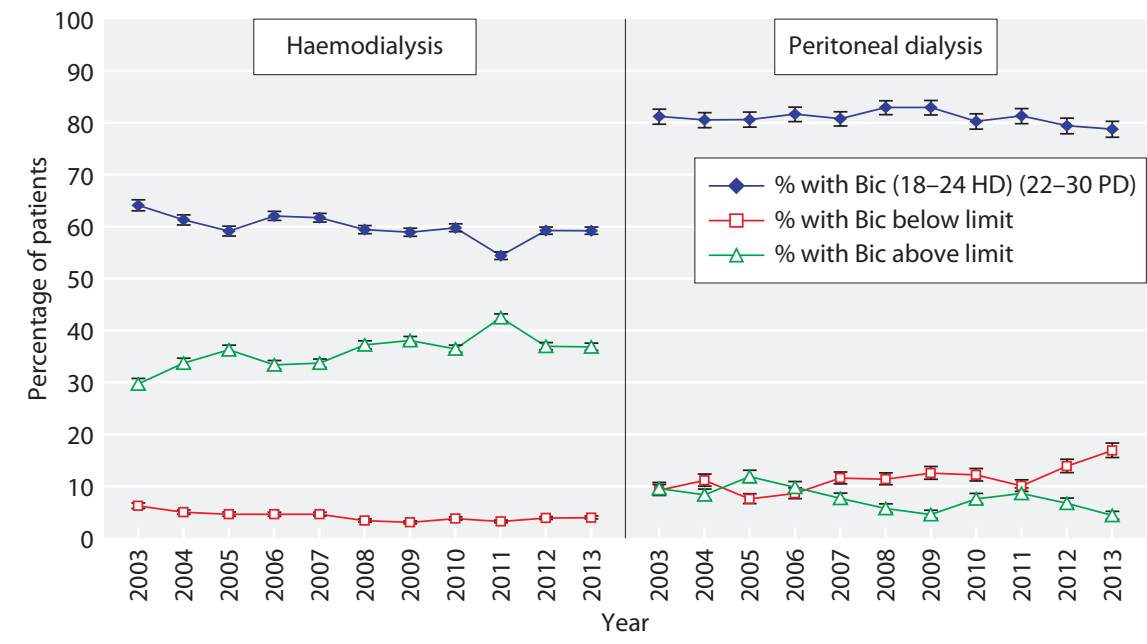

Fig. 8.24. Longitudinal change in percentage of patients within the range for bicarbonate (18-24 mmol/L for HD and 22-30 $\mathrm{mmol} / \mathrm{L}$ for PD) by dialysis modality 2003-2013 bicarbonate concentrations (Carshalton, Dudley, Kent, London St Bartholemew's, London Guy's, Plymouth, Wirral, Wolverhampton).

Serial trends in serum bicarbonate measures between 2003 and 2013 by dialysis modality are presented in figure 8.24. Sample processing, case-mix, differences in dialysis, residual renal function and oral bicarbonate prescriptions may all contribute to the variation observed.

\section{Conclusions}

The UKRR has consistently demonstrated between centre variation in achievement of audit measures for bone and mineral parameters but little is understood about the causes of this 'centre effect'. The complexity of the clinical processes required to manage mineral and bone disorders is probably further confounded by case-mix. In the future, with centres moving to newer IT systems, medications used in the management of bone and mineral diseases may become available to aid in better analyses of these parameters.

Additionally, it is important to consider data quality and the potential for measurement error particularly in light of the variability in assay methods, for example for parathyroid hormone. However, detecting these centre level differences is an important step in understanding the factors associated with variation in performance. Some specifics for consideration are highlighted below.

\section{Bone Mineral Variables}

Observational data support that hyperphosphataemia is associated with increased mortality in dialysis patients but the data linking calcium and parathyroid hormone to patient survival are less clear [9-13]. A cohort study has however suggested that simultaneous achievement of all three audit measures does appear to be associated with better patient outcomes [14].

\section{Possible issues relating to calcium measures}

The current RA guidelines are based upon measures of adjusted serum calcium [3]. A variety of formulae have been proposed to permit calculation of the 'adjusted' total calcium (i.e. an estimation of the expected total calcium were the serum albumin normal) from the total calcium and albumin concentration, but there are no data to support the use of mathematical corrections of serum calcium amongst patients with ERF. This topic was discussed in detail in the 2009 annual report and most of the shortcomings remain [15]. However, the ongoing restructuring of pathology into a smaller number of services together with harmonisation should increase measurement uniformity across laboratories and hence renal centres. UK laboratories are still in the process of adopting the guidelines to harmonise albumin-adjusted calcium reference ranges to $2.2-2.6 \mathrm{mmol} / \mathrm{L}$ using method-specific adjustment equations normalised to a mean calcium of $2.4 \mathrm{mmol} / \mathrm{L}$. Until this process is complete, differences between laboratories in the reported adjusted calcium are likely to continue. Meanwhile, centres must work with their laboratories to ensure that 
the calcium results are adjusted correctly for the methods in use. These problems must be borne in mind when trying to interpret the figures that compare serum adjusted calcium achieved in different renal centres.

Centres should also be aware that achievement of the audit standard can however mask population shifts in concentration. This can be illustrated by data from the Royal Free for HD patients: in 2011 30\% had an adjusted calcium $<2.2 \mathrm{mmol} / \mathrm{L}, 65 \%$ were within range, and $5 \%$ were $>2.5 \mathrm{mmol} / \mathrm{L}$; in $20124 \%$ had an adjusted calcium $<2.2 \mathrm{mmol} / \mathrm{L}, 77 \%$ were within range and $19 \%$ were $>2.5 \mathrm{mmol} / \mathrm{L}$. A similar pattern was observed in PD patients. However, the figures for unadjusted calcium remained stable. This shift can be attributed to a change in the equation used to adjust calcium that was introduced on July 6th 2012 before the UKRR collection of data in the last two quarters. The new equation increased adjusted calcium values by approximately $0.2 \mathrm{mmol} / \mathrm{L}$. It was subsequently recognised that the new equation was over-adjusting calcium results and a revised equation was introduced from October 2013 that conformed to current harmonisation guidelines. Accordingly for 2013, the Royal Free show a decline from 19\% (2012) to 5\% $>2.5 \mathrm{mmol} / \mathrm{L}$, an increase from $4 \%$ (2012) to $10 \%$ $<2.2 \mathrm{mmol} / \mathrm{L}$ and an increase from $77 \%$ (2012) to $86 \%$ within range. Mean and median adjusted calcium fell from $2.4 \mathrm{mmol} / \mathrm{L} \mathrm{(2012)} \mathrm{to} 2.3 \mathrm{mmol} / \mathrm{L}$ in 2013 . These shifts were mirrored in the PD population at the Royal Free. A similar change was observed in Newcastle's HD data following a change in the equation to conform with harmonisation guidelines in April 2013 that increased the adjusted calcium - compared with 2012, the 2013 data show a decrease in results $<2.2 \mathrm{mmol} / \mathrm{L}$ (from $22 \%$ to $8 \%$ ).

Centres showing significant shifts in any biochemical parameter should consider whether there have been any changes in laboratory methodology that may account for the apparent deterioration or whether it is truly treatment-related.
Possible issues relating to PTH measures

A significant contributor to centre variation will be the assay used to measure PTH. This has been demonstrated by a study undertaken by the Scottish Clinical Biochemistry Managed Diagnostic Network in association with the Scottish Renal Registry [16]. Analysis of samples from 106 haemodialysis patients by six different PTH immunoassays in common use showed a 1.2- to 2.7fold variation in results in spite of similar reference ranges for each method. Since current guidelines refer to multiples of the upper reference limit, $53 \%$ of patients were classified differently by different methods with implications for treatment e.g. with Cinacalcet. In an accompanying editorial, Garrett and Goldsmith also highlighted the high biological variability of PTH and its poor ability to predict skeletal or patient outcomes [17]. Whether more accurate and specific assays would improve this or whether PTH will be supplanted by other markers such as bone specific alkaline phosphatase that also have greater pre-analytical stability remains to be determined.

Improvement of $\mathrm{PTH}$ assays to achieve consensus results within $\mathrm{CKD}$ patients requires manufacturers to consider two principal factors: adoption of a common reference preparation for standardisation, such as the WHO international standard 95/646, and selection of pairs of antibodies that do not detect PTH fragments such as 7-84 that accumulate in CKD. Meanwhile Almond et al and a further editorial review urge adoption of assay-specific action limits for PTH in CKD patients $[16,18]$. However, this approach raises a number of difficult governance issues. There is already evidence that the manufacturers of the major diagnostic platforms used throughout the world have started to respond. The Roche assay used by Almond et al was PTH (intact) that was not standardised and cross-reacted with PTH 7-84 [16].

Conflicts of interest: none

\section{References}

1 Renal Association: Clinical Practice Guidelines. 5th Edition. http://www. renal.org/Clinical/GuidelinesSection/Guidelines.aspx

2 Ansell D, Tomson CRV: Chapter 15 UK Renal Registry Annual Report: UK Renal Registry, UKRR database, validation and methodology. Nephron Clin Pract. 2009;111(Suppl 1):c277-85

3 Steddon S, Sharpes E: Renal Association Clinical Practice Guideline. CKD-Mineral and Bone Disorders, 2010. http://www.renal.org/ guidelines/modules/ckd-mineral-and-bone-disorders

4 Morton AR, Garland JS, Holden RM: Is the calcium correct? Measuring serum calcium in dialysis patients. Semin Dial. 2010;23(3): 283-289

5 Kidney Disease: Improving Global Outcomes (KDIGO) CKD-MBD Work Group: KDIGO clinical practice guideline for the diagnosis, evaluation, prevention, and treatment of chronic kidney disease-mineral and bone disorder (CKD-MBD). Kidney International 2009; 76(Suppl 113): S1-S130 
6 Spiegelhalter DJ: Funnel plots for comparing institutional performance. Statistics in Medicine 2005;24:1185-1202

7 Mactier R, Hoenich N, Breen C: Renal Association Clinical Practice Guideline Haemodialysis, 2009. http://www.renal.org/Clinical/Guidelines Section/Haemodialysis.aspx

8 Woodrow G, Davies S: Renal Association Clinical Practice Guideline Peritoneal Dialysis, 2010. http://www.renal.org/Clinical/Guidelines Section/PeritonealDialysis.aspx

-9 Kalantar-Zadeh K, Kuwae N, Regidor DL, Kovesdy CP, Kilpatrick RD, Shinaberger CS, McAllister CJ, Budoff MJ, Salusky IB, Kopple JD: Survival predictability of time-varying indicators of bone disease in maintenance hemodialysis patients. Kidney Int 2006;70:771-780

10 Melamed ML, Eustace JA, Plantinga L, Jaar BG, Fink NE, Coresh J, Klag MJ, Powe NR: Changes in serum calcium, phosphate, and pth and the risk of death in incident dialysis patients: A longitudinal study. Kidney Int 2006;70:351-357

11 Noordzij M, Korevaar JC, Boeschoten EW, Dekker FW, Bos WJ, Krediet RT: The kidney disease outcomes quality initiative (k/doqi) guideline for bone metabolism and disease in ckd: Association with mortality in dialysis patients. Am J Kidney Dis 2005;46:925-932

$\checkmark 12$ Stevens LA, Djurdjev O, Cardew S, Cameron EC, Levin A: Calcium, phosphate, and parathyroid hormone levels in combination and as a function of dialysis duration predict mortality: Evidence for the complexity of the association between mineral metabolism and outcomes. J Am Soc Nephrol 2004;15:770-779

13 Block GA, Klassen PS, Lazarus JM, Ofsthun N, Lowrie EG, Chertow GM: Mineral metabolism, mortality, and morbidity in maintenance hemodialysis. J Am Soc Nephrol 2004;15:2208-2218

14 Danese MD, Belozeroff V, Smirnakis K, Rothman KJ: Consistent control of mineral and bone disorder in incident hemodialysis patients. Clin J Am Soc Nephrol 2008;2:2

15 Ansell D, Tomson CRV: Twelfth Annual Report: Chapter 10 Biochemistry Profile of Patients Receiving Dialysis in the UK in 2008: national and centre-specific analyses. Bristol, UK Renal Registry, 2009

16 Almond A, Ellis AR, Walker SW: Current parathyroid hormone immunoassays do not adequately meet the needs of patients with chronic kidney disease. Ann Clin Biochem 2011;49:63-67

17 Garrett G, Goldsmith DJA: Parathyroid hormone measurements, guidelines statements and clinical treatments: a real world cautionary tale. Ann Clin Biochem 2011;49:4-6

18 Sturgeon CM, Sprague SM, Metcalfe W: Variation in parathyroid hormone immunoassay results - a critical governance issue in the management of chronic kidney disease. Nephrol Dial Transplant 2011;26:3440-3445 